\title{
DEVELOPMENT AND EVALUATION OF RADON SEALANTS FOR URANIUM MINES
}

H. G. Hammon

K. Ernst

J. R. Gaskill

J. C. Newton

C. J. Morris

May 21, 1975

Prepared for U.S. Energy Research \& Development

Adminisiration under contract No. W-7405-Eng-48

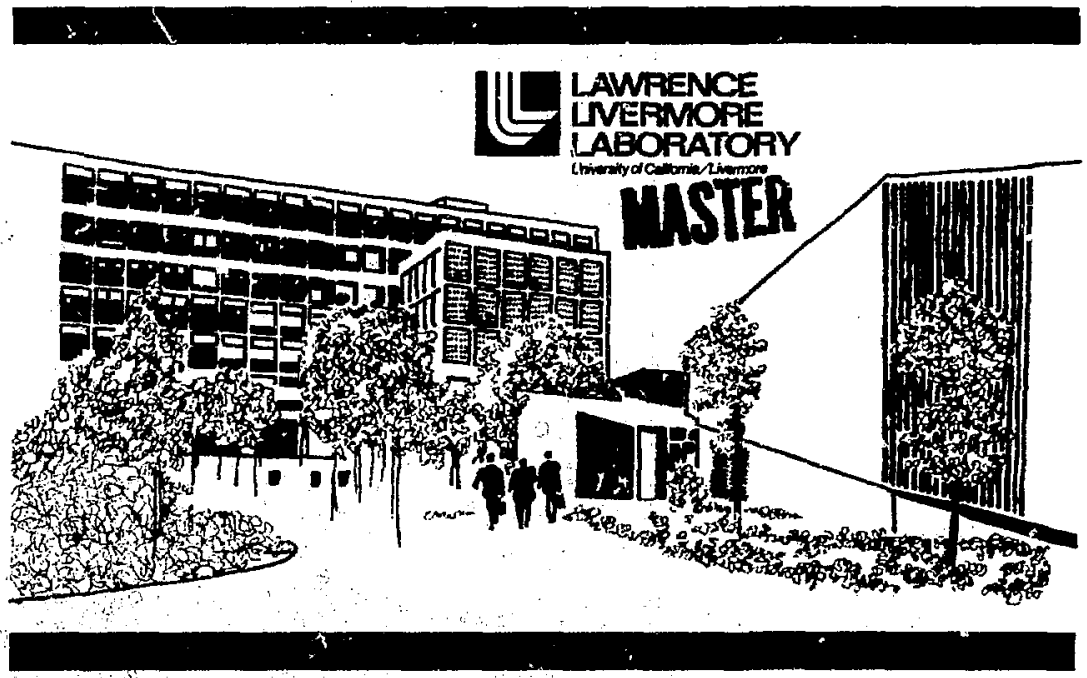


Notice.

"This report was prepared as an account of work sponsored by the United Stetes Government. Neither the United Stotes nor the United-States Enersy Recench 2 Development Administration, nor any of their employecs, nor any of their contractors. 5utcoitretors, or their employees, makes any wattenty, exprets or imolied, of essumes any lesal linbility of respongibility for the gecutacy. completeness or unfulness of any information, completeness or unfulness of any information,
apparntus, pioduct of peocess disclosed, of represents that its use would not infringe orivtely-ouned ristits."

Printed in the United States of America Available from

National Technical Information Service

U.S. Department of Commerce 5285 Port Royal Road

Springfield, Virginia 22151

Price: Printed Copy $\$$; Microfiche $\$ 2.25$

* Pages

$1-50$

$51-150$

$151-325$

$326-500$

$501-1000$
NTIS

Selling Price

$\$ 4.00$

$\$ 5.45$

$\$ 7.60$

$\$ 10.60$

$\$ 13.80$ 


\title{
난 \\ LAWRENCE LNERMORE LABORATORY

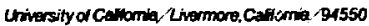

UCRL-51818

\section{DEVELOPMENT AND EVALUATION OF RADON SEALANTS FOR URANIUM MINES}

\author{
H. George Hammon \\ Klaus Ernst \\ James R. Gaskill \\ John C. Newton \\ C. J. Morris
}

\begin{abstract}
USBM CONTRAC'I REPORT HO232047
May 29, 1975

DEPARTMENT OF THE INTERIOR

BUREAU OF MINES

WASHINGTON, D.C.
\end{abstract}

\section{NOTICE}

The views and conclusions contained in this document are those of the authors and shouId not be interpreted as necessarily representing the official policies or recommendations of the Interior Department's Bureau of Mines or of the U.S. Government.

This report wh prepared as an sccount of work cponsared by the Uniled Sutes Governanent. Neither the United Sutes nor the United St.te Energy Reverch and Development Administration, nor any of thet employess, nor any of their contractors, subcontration, or their employees, makes an varnaty, express of implied, or useumes any legal liability or remonsibility for the accuracy, completenes or uefulnes of any information, appantus, product or process disclosed, of represents that its use would not infringe privately owned rights. 


\section{Foreword}

This report was prepared by Lawrence Livermore Laboratory, Livermore, California under USBM Contract Number H0232047. The contract was int. tiated under the Metal and Nonmetal Health and Safety Research Program, It was administered under the technical direction of SMRC with Mr. John $\mathbf{C}$. Franklin acting as the Technical Project Officer. Mr. Frank Pavlich was the contract administrator for the Bureau of Mines.

This report is a summary of the work secently completed as part of this contract during the period October, 1972, to February, 1975. This report was submitted by the authors on May 29, 1975.
Work was performed under the auspices of the U.S. Energy Research \& Development Administration. Reference to a company or product name does no: imply approval or recommendation of the product by the University of Californiz or the U.S. Energy Research \& Development Administration to the exclusion of others that may be suitable.

The authors acknowledge gratefully the assistance of many others in this work, especially tiloyd Momyer for direct radon permeation measurements, Jamus $S$. Johnson for toxicity evaluations, and Norriss Hetherington for statisticil and mathematical analysis. 


\section{Contents}

Fureword . . . . . . . . . . . . . . . . . . . . . . . . ii

Introduction . . . . . . . . . . . . . . . . . . . . . . . . . . . . . . . . 1

Summary and Conclusions. . . . . . . . . . . . . . . . . . . . . . . . . . . . 1

Experimental Work . . . . . . . . . . . . . . . . . . . . . . . . . . . 3

Task 1: Coating Selection and Preparation . . . . . . . . . . . . . . . . . . . . 3

Task 2: Measurement of Permeability and Diffusion Constants . . . . . . . . . . . . . . . 3

1. Dynamic Metlud Ulsing a Mass Spectrome ter as a Gas Detector . . . . . . . . . i

2. Usc ol Dow Cell fo: Permeability Measurements . . . . . . . . . . . . . . 5

3. Direct Determination of Rudon Permeability . . . . . . . . . . . . 5

Results and Discussion of Pe rmeability Study . . . . . . . . . . . . . . . . . . . c

Modification of Coatings . . . . . . . . . . . . . . . . . . . . . . 10

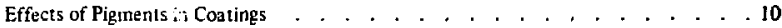

Effects of Crussinking . . . . . . . . . . . . . . . 10

Tluckening Agents . . . . . . . . . . . . . . . . . . . . . . 11

Correlation of Pernieability with Polymer Structure . . . . . . . . . . . 11

Permeability of Uranium Ore . . . . . . . . . . . . . . . . . . . . 14

Task 3: Evaluation of Toxicity of Coatings . . . . . . . . . . . . . . . . . . 14

Smoke Chamber Studies of Cuatings . . . . . . . . . . . . . . . . 15

Preparation ot Specimens . . . . . . . . . . . . . . 15

Smoke Chamber Tests . . . . . . . . . . . . . . . 15

Flash Points of Coatings . . . . . . . . . . . . . . . . . . . . If

Lijuratory Pyzolysis Test Under Non-Flaming Conditions . . . . . . . . . . . . 18

Results and Discussion . . . . . . . . . . . . . . . 18

GC/MS Analysis of Volatiles from Polymers . . . . . . . . . . . . . . . . . 21

Toxicological Eviluation of Coatings . . . . . . . . . . . . . . . . . . 23

References. . . . . . . . . . . . . . . . . . . . . . . . . 24

Appendix A: Tables and Figures . . . . . . . . . . . . . . . . . . . . . . . . . 25

Appendix B: Computer Program (PDP.8) for Calculation of Permeability Coefficients from Dow Cell Data. 54

Appendix C: Direct Determination of Radon Permeability through Polycarbonate Fîlm . . . . . . . . 57 


\section{Introduction}

Uranium miners have been shown to develop lung cancer in direct proportion to the time of exposure in the mine and the concentration of radiuactivity (cunulative working level). ${ }^{1}$ Radon gas is continually evolyed from the uranium ore, but because of its slior? hulf-iffe, 3.82 days, it is soun decomposed into particulate daughter products, which, along with the dust in the mine, become deposited in the miners' lungs. At present, massive ventilation is the only effective method of reducing the radioactivity concentration in the mines. However, the Buresu of Mines is evaluj. ting the possibility of using coatings on the minte walls that will have sufficiently low permeability to radinn that the gas will decompose into the particuiate daughter products before it can permeate the cuating. Permanently trapped in the coating, the daughter products wouid be prevented from dispersing in the mine atmosphere.

Lawrence Livermore Lau Jratory was asked to aid in this investigation. The direct deternination of radon permeability is more difficult than that of the other noble gases because of the short half.life of the gas and radioactive contamination of the apparatus. We felt that it should be possible to estimate radon permeation coefficients from other noble gas permeatiun cueliticients. It was noted that the $\log$ of the diffusion constants for helium, neon. argon, and krypton. as repurted by Meares ${ }^{2.3}$ plotted to a straight line ugainst the square of the gas molecular djameter. The log of the permeation cuelficients also plotted to a straight line apainst the square of the gas molecular diantetes. Thus, by determining the permeation coefficients of such gases as argun and krypton through various films and coatings, it appeared likely that radon permeation soeiricients could be estimated. In additiun, we felt it should be pussible to find sume relation. ship between polymer structure and the noble gas permeation cuefficient that would aid in the selection of coatings materials as mdon barriers.

As the program progressed. we were asked io evaluare selested coatings for their possible toxicity during upplication or it mine fire. As the cuatings were of industrial origin, it was possible that they might contain volatile materisls that would puse a toxicological hazard to personnel while applying costings to the mine walls. Also, a mine fire might be made more hazardous by dense smoke from the coating or toxic materials emitted during its pyrolysis.

\section{Summary and Conclusions}

The purpose of this study was to evaluate selected coatings as radon barriers in uranium mines; first on their effectiveness in reducing radon permeation, and second on the basis of titeir potential toxicity during application or in a possible mine fire. Hopefully, this information would be helpful in developing coatings more effective than those commercially ivailable.

The program was organiced in three tasks:

(1) Film Selection and Preparation; (2) Measurement of Permeability; and (3) Evaluation of Toxicity of

\section{Coatings.}

Films for the pcrmeation study were selected from commercinlly available polymer systems of known chemical composition. Cuating systems were selected on the basis of their chemical composition using our uwn permeability dala or published dats to aid in selections; other coatings previously evaluated at Bureau of Mines wers alsu studied. In agreement with the Bureau of Mines saven coatings were selected for fult evaluation. includizg smoke chamber and toxicity studies. Twu more were added later for smuke cham. ber study only. Permealian coefficients of he films and cuatings to noble gaties wert determined. When the log of the perneation coefficients for argon. krypton and xenon is pllottid against the square of the mulecular diameter 3 Jincar ref.tionship is ub tuined. Thus, a straight--line extrapolat ion of this line permits the estimation of the perneatility cosifi:ient for radon. The latter may be undesirable as surface coatings because they yield lirge announts of hydrogen 
chloride (HCl) when exposed to heat or fire: however. they produce negligible amounts of smoke. They might be useful as penetrating compositions to bond loose uranium ore. The one-coniponent golyester develops only light smoke. but would be hazardoss during application because it releases relatively large amounts of styjene vapors, and has a low flash point.

The furan coating has very low permeability to noble gases. and develops regligible umounts of smoke. However, it has an objectionsble odor which would be difficult to mask, and its black color miglt be undesirable.

Three epoxy coatings were evaluated. Two of these were unpigmented; they developed dense smoke when exposed to heat or fire. The pigmented epoxy coating produced only a liglı smoke, and its vapors contained no toxic components.

Toxic components evolved from the uncured polymer systems were determined by gas chromotography/ mass spectrography (GC'MS). The only materials of toxicological significance that were found were vinyiidene chloride (a suspected carcinogen) in the vinylidene chloride copolymer, vinyl chloride (a carcinogen) in one of the unpigmented epoxy coatings, and epichloreshydrin (a sensitizer), in the same epoxy cuating.

Pyrolysis studies vere made on the cured coatings. Other than carbon monoxide and $\mathrm{HCl}$ no significant quantities of other coxic species were found. Carbon monoxide was not generated from any of the coatings in a mounts that would be large compared with those that would be evolved from other materials usually involved in a mine fire, such as wood, diesel fuel, and waste inaterials.

In ranking the coatings studied, we should note that they represent only a few of such commercial coatings available: other manufacturers may nake similar coatings. Also, the ranking gives relatively little weight to permeability, as all are adequate to stop radon in the normal thickness of application, providing a continuous coating is effected. Finally, costings 8 anc 9 were evaluated only in the sntoke chamber, but produced mari smoke than most of the other costings under these conditions. Thus. we rank the coatings in decreasing order of overall effectiveness as follows:
Naine and Type

l. HydrEpoxy 300. pigmented waterdispersed epoxy

2. Resitron II, furan (catalyzed furluryl alcohol polymes)

3. Essex Polyester, pigmented one-component styrenated polyester

4. Aerospray 70. plasticized pulyvinyl acelate latex

5. Saran XD-7151, vinylidene chloride copolymer

6. EjiRez WD-510/EpiCure 872, unipigmented water. ditpersed epoxy

7. WSU-118, mudified tpuxy

8. Promulsion 200, unidentified composition

9. Hydro Sesl, acrylic emulsion
Comments

Bad odor

Flammable: contains slyrene

Possible smake problem

Liberates hydrogen chloride in possible fire Possible smoike problem

Possible smoke problem

Possible smoke problem Possible smoke problem
We have calculated that virtually all roatings with permeation constants lower than $10^{-10} \mathrm{~cm}_{\mathrm{STP}}^{3} \cdot \mathrm{cm} /$ $\mathrm{s}=\mathrm{cm}^{2}+\mathrm{cm} \mathrm{Hg}$ and thicknesses between $\mathrm{s}$ and 10 mil will provide nearly $100 \%$ effectiveness. The selection of a suitable coating then ought to be based on other factors such as cost $/ \mathrm{m}^{2}$, vapor toxicity during application, ability to bind to the uranium ore in continuous films free of pin-holes etc. Obviously, any openings in the mine shafts and tunnels which are not covered with a film or any discontinuities of the film with act like the spiliway on a water dam, i.e., the radon contained behind the barrier will flow out into the turnel. 


\section{Experimental Work}

The study of radon seulants for uranium mines w.ts organized as the te iusks: (1) Couline Selection and Preparation; (2) Measumement of Perrieability and Diffusion Constunts: and (3) Evaluation of Toxicity of Coalings. Although there was overlapping of these tusks, this was atso the chronological ordes in which the study was made.

\section{TASK 1: COATING SELECTION AND PREPARATION}

Many of the coatings eraluated at LLL had previously been studied at Bureau of Mines, SMRC. Additionally, we surveyed the chr mical industry and obtanned specimens of coatings mateials for evaluation. As muclt as possible. the composition of the coatings was obtained from the manutacturer. Pernieability studies were al so madic on contnercial fi, know'n composition, and these results were used as a basis for selection of coatings.

Most of the cuatings were prepared by drawdown from solution or latex using a doctor biade on a sub. strate of known permeability. This substrate was usually a polyethylene iononer (Suriyn A). This muterial had high permusbility and wetted better than conventional polyethylene. The coatings were allowed to dry thoroughly at room temperature and were conditioned for scveral days at about $50^{\circ}$; relative hunidity. The thickness of unsuppor1ed coatings or coatings on the Surlyn A substrate was measured with an electronic micrometer and averaged values were rounded off to the nearest $0.025 \mathrm{~mm}(0.0001 \mathrm{in}$.).

Coatings for evaluation in the LLL/NBS Smoke Chunber were applied. usually by spraying. to the surface of $73 \times 73 \times 25 \mathrm{~min}$ cement-asbestos board specimens. In some cuses, similar size specimens were cut from low-grade uraniun ore and xere coated for smoke-chamber study. Results with coatings on uranium ore specimens were essentially the same as with cement-asbestos board specimens. It was costly to cut the ore specimrens and their uranium content required special monitoring procedures. Therefore, muri determinations were made on cement-asbestos board spectmens. Coatings on the cement-asbestos hoard or uranium ure specimens we te measured indire: 1 ly by bonding a thin steel stech to the surface of a similar specimen. couting it at the same time and in the same nunner as the speciments to be evaluated in the smoke thamber. and measuring the thickness of the cured soat ing with a magne tic cuating thickness gage.

\section{TASK 2: MEASL'REMENT OF PERMEABILTY AND DIFFLSION CONSTANTS}

\section{Dynamic Metliod Using a Mass Spectrometer as a Gas Detecitor}

In this dynantic technique a small mass spectrometer (a converted CEC $21-614$ Residual Gas Analyzer) serves as gas detector. The specificity, sensitivity and precision ara supetior to most other detectors. For thin film: (up to 15 mils) this method gives results rapidly. and interfering membrane outgassing and desorption gasss san be distinguished from the permeant. The presence of pinholes in, or lesks around, the inembrane is readily recognitred. A schematic of the measurement system is shown in Fig. 1 . The specially designed perneation cell is connected to the ion source via an isolation valve. In the open position the fow inpedance of the valve port is negligible relative to the How impedance of the membrane. By using two Viton $\mathrm{O}$-rings and continuously pumping on the volume between the $\mathrm{O}$-rings. air leaks are virtually elininsted.

The $\mathrm{O}$-rings are vacuum baked before assembling the cell to remove dissolved gases and water vapor. This cell can be heated to about $150^{\circ} \mathrm{C}$ and the membrane thickness can be varied from 1 mil to about 65 ,ilis. In operation, the permeation cell is evacuated on both sides of the inembrane and a spectruin of the residual gases is obtained. If any of these gases are identical to the pesmeant to be usad (the test gas) evacuation continues until the background is negligible. If this requires too much time, the outgassing and/or desorption rates are measured as function of time to be used as correction factors to the permeation rate. The isolation valve in the spectrometer is 


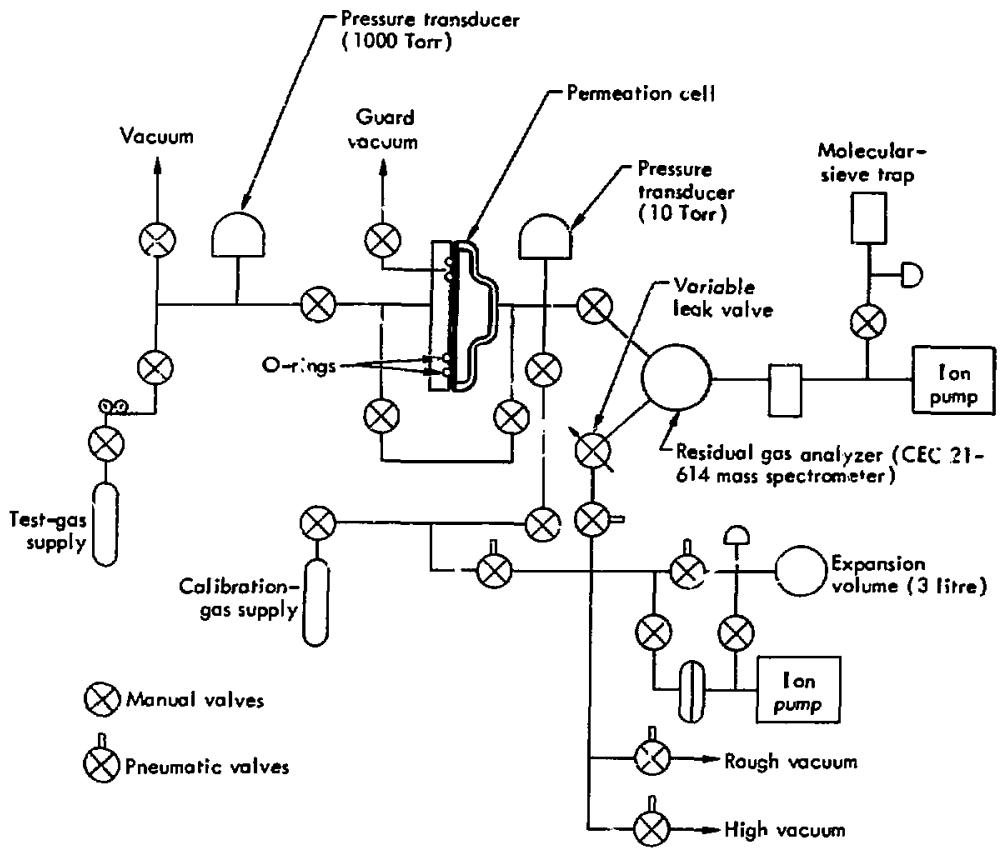

Fig. 1. Diagram of the mass spectrometer and associated apparatus that was used for measurement of permeability constants. 
thrs opened and the test gus is applied at a known pressure $\left(\mathbf{P}_{\mathbf{i}}\right)$ on the in going side $\mathrm{f}$ t the membrone. A suitsble ion peak ( $\mathrm{m} / \mathrm{c}=4 \mathrm{for}$ helium: $\mathrm{m} / \mathrm{c}=40 \mathrm{for}$ $A_{r}: m_{j}:=83.84$ or 86 for $K r l$ is continuously monitored until the recusder trace or digital oulput reachles in steady stule vilue.

Mie systetn is collibrated by measuring the miss spectrometer's clectrulteter respunse to a kniwin. constant how of the test eus which furnishes the serit. sitivily (S). The steady-5tute permeation rate (Q்) is obtained from the relasion

$$
\dot{Q}=s \cdot v_{5 s} \text {. }
$$

where

$$
\begin{aligned}
\dot{Q} & =\text { permestion rate }\left(\mathrm{cm}_{\text {STPP }}^{3} / \mathrm{s}\right) \\
S & =\text { sensitivity }\left(\mathrm{cm}_{\mathrm{STP}}^{3} / \mathrm{s} \cdot \mathrm{riV}\right) \\
V_{s \mathrm{~s}} & =\text { electrometer signal at steady state }(\mathrm{mV}) .
\end{aligned}
$$

Frum alis. the pefmeation coefitcient is calculated using the following equation:

$$
P=\dot{Q} \cdot d / A \Delta p \text {. }
$$

where

$$
\begin{aligned}
d= & \text { membrune thickness }(\mathrm{cm}) \\
A= & \text { ulembrane area }\left(\mathrm{cm}^{2}\right) \\
\Delta P= & p_{1}-P_{2}=F_{1}=\text { test gas pressure }(\mathrm{cm} \mathrm{H}) \\
P= & \text { permestion coefficient }\left(\mathrm{cm}_{\text {STP }}{ }^{3} \mathrm{~cm} / \mathrm{s} \cdot \mathrm{cm}^{2}\right. \\
& \cdot \mathrm{cm} \mathrm{Hg}) l .
\end{aligned}
$$

Frum d single experiment we can also calculate ilie diffusion constant (D) by the method of Pasternak* if the complete permeation curve from zelo transmission to the steady state vaiue is obtained. Since

$$
P(T)=D(T) s(T) \text {. }
$$

the solubility (c) con be culculated with P and D determined. All three terms ase temperature dejen. dent. Experiments at different temperatures permit the measturement of the temperature coefficien's.
2. Usi of Dow Cill lar Perméability Measuremerts

Determinations af presmesbility wefficients using the uass spectromener of ten requir od long tumes. exputially with low permezbility filns and coutings and with the highter mulecular weight gases such as kirpton and xesion. Therefore. we made inary of out determinatiuns with a Dow film permeability celt. Ea described in ASTM D-1434.66. A computer program was witlen for a PDP.8 to calculate perrealion coefticients froun the experimentat data: the program is sliown in Appertidix $B$.

3. Direcal Determinusions of Radon Permeshults

Redon perineation nessurements ale mure dificult to maks than thuse of ather nothle gases for a number of teusuns. For must polar intale, bits. the jadon permedzion rate will be solow due to lla larger gist molecule and its sluwer diffusiun rate. It has a teldtively shont lialf life. Ulus deposits its daughte!t preducts in the measuring spparstus. We did ne? wast to so contaminate the mass spetitrenteler w. the bew cell. Therefore, dited detarmination of radon permeation through polyethylene and through polyurinonate fillns was inade using radiothanical techniqus with apparatus made for the purpose from bo-tmm pytex glass tubing. Radon. derived fiom a rustum solution. was admitted to one side of the apparatus. and allowed to permeate the film which separated the apparatus into two chanbers. The gas which permeated the filn was deterınined on the uther side by alplia counting. Complete details of the determigation of the radon permeability coefficient of polycarbonate film ar: described in Appendix $C$ by Dr. Floyd Momyer, who was in charge of this ohase of the work. 


\section{RESULTS AND DISCUSSION OF PERMEABILITY STUDY}

The permeation coetficients of sme contmercial films are listed in Table 1 and the permeition coeffcjents of some supported cuatings are listed in Table 2. A complete listing of the permeation coefficients of the supported coatings will be found in Table A-1 in $A$ ppendix A. Some of these data are plotted in Figs. 2 and 3 as the logs of the permeation coefficients vs the square of the diameter of the permeant pas. In general, good straight line fits were ubtained for argon, kryplon, and yenon permestion coefficients, al though the helium and neon permeation coefficients did not urually fit well with the other datj. Direct mejsurements of the radon $p$ "rmeation cocfficients were made only through polyethytene and polycurbonate films. As may be seen from Fig. 2, these values agreed wel! with values that would be predicted by extrapolation of the argon. krypton. and xenon values.

Tite perneation coefficients for noble gases through polycthylene and Surlyn $A$ increase with increasing gas niolecular iveight and diameter. Similar effects have been reported in neon and argon permeation through ethylene-propylene copolymers, styrene-butadiene copolymers, and a cis-polybutadiene ${ }^{5}$, for neon, argon, krypton, and xenon through naturai sabber ${ }^{6}$, and for neon, argon, krypton, and xenon through silicone rubber $^{7}$. In polymers of higher cohesive energy

Table 1. Perneation cuefticients of conmercial fijms.

\begin{tabular}{|c|c|c|c|}
\hline Film & Gas & \multicolumn{2}{|c|}{ Permeation coefficients } \\
\hline & & $\mathrm{cm}_{\mathrm{STP}}^{3} \cdot \mathrm{cm}$ & $\mathrm{nm}^{2}$ \\
\hline & & $\overline{\mathrm{sec}} \cdot \mathrm{cm}^{2} \cdot \mathrm{cm} \mathrm{Hg}$ & $\overline{\mathrm{Pa} \cdot \mathrm{s}}$ \\
\hline \multirow[t]{5}{*}{ Polyethylene } & $\mathrm{He}$ & $6.7 \times 10^{-10}$ & 50 \\
\hline & AI & $3.4 \times 10^{-10}$ & 25 \\
\hline & $\mathbf{K r}$ & $4.5 \times 10^{-10}$ & 34 \\
\hline & $\mathrm{Xe}$ & $8 \times 10^{-10}$ & 60 \\
\hline & $\mathbf{R n}$ & $1.5 \times 10^{-9}$ & 113 \\
\hline Surlyn A & $\mathrm{Na}_{\mathrm{s}}$ & $2.0 \times 10^{-10}$ & 15 \\
\hline \multirow[t]{3}{*}{ (polyethylene ionomer) } & $\mathrm{Ar}$ & $1.3 \times 10^{-10}$ & 9.8 \\
\hline & $\mathbf{K r}$ & $1.5 \times 10^{-10}$ & 11 \\
\hline & $\mathrm{Xe}$ & $1.9 \times 10^{-10}$ & 14 \\
\hline \multirow[t]{5}{*}{ Polycartonate } & $\mathrm{He}$ & $1.5 \times 10^{-9}$ & 113 \\
\hline & $\mathrm{Ar}$ & $5.5 \times 10^{-11}$ & 4.1 \\
\hline & $\mathrm{Kr}$ & $5 \times 10^{-11}$ & 3.8 \\
\hline & $\mathrm{Xe}_{\mathrm{e}}$ & $2 \times 10^{-11}$ & 1.5 \\
\hline & Rn & $1.8 \times 10^{-11}$ & 1.4 \\
\hline \multirow{4}{*}{$\begin{array}{l}\text { Polyvinylchloride, } \\
\text { unplasticized }\end{array}$} & $\mathrm{He}$ & $4.0 \times 10^{-10}$ & 30 \\
\hline & Ar & $7.0 \times 10^{-12}$ & 0.53 \\
\hline & $\mathrm{Kr}$ & $3.5 \times 10^{-12}$ & 0.26 \\
\hline & $\mathrm{Xe}$ & $4 \times 10^{-13}$ & 0.03 \\
\hline \multirow[t]{4}{*}{ Phenoxy } & $\mathrm{Ne}$ & $2.5 \times 10^{-11}$ & 1.9 \\
\hline & $A \mathbf{r}$ & $2.6 \times 10^{-12}$ & 0.20 \\
\hline & $\mathrm{Kr}$ & $1.1 \times 10^{-12}$ & 0.08 \\
\hline & $\mathrm{Xe}$ & $2.1 \times 10^{-13}$ & 0.016 \\
\hline
\end{tabular}


Table 2. Petmeation coefficients of supporled cuatings.

\begin{tabular}{|c|c|c|c|}
\hline \multirow[t]{4}{*}{ Description } & \multicolumn{3}{|c|}{ Permeation coefficienls. } \\
\hline & \multirow[b]{3}{*}{$A_{I}$} & $\mathrm{~cm}_{\mathrm{STP}}^{3} \cdot \mathrm{cm}$ & \multirow{3}{*}{5} \\
\hline & & $\mathrm{s} \cdot \mathrm{cm}^{2} \cdot \mathrm{cm} \mathrm{Hg}$ & \\
\hline & & $\mathbf{K r}$ & \\
\hline Polymethyl acrylate, low viscosity & $3.9 \times 10^{-11}(2.9)$ & N.D. & N.D. \\
\hline Vinyl chloride copolyıner, latex & $6.0 \times 10^{-12}(0.45)$ & N.D. & N.D. \\
\hline Vinylidene chloride copolymer, latex & $4.4 \times 10^{-13}(0.033)$ & $2.2 \times 10^{-13}(0.017)$ & $8.9 \times 10^{-14}(0.0067)$ \\
\hline Epoxy, pigmented, from water dispersion & $7.3 \times 10^{-12}(0.55)$ & $6.8 \times 10^{-12}(0.51)$ & $5.0 \times 10^{-12}(0.38)$ \\
\hline $\begin{array}{l}\text { Epoxy, not pignented, from water } \\
\text { dispersioll }\end{array}$ & $1.1 \times 10^{-11}(0.83)$ & $7.7 \times 10^{-12}(0.58)$ & $3.5 \times 10^{-12}(0.26)$ \\
\hline Polyvinylacetate, plasticized. iatex & $\therefore .4 \times 10^{-11}(1.8)$ & $1.1 \times 10^{-11}(0.83)$ & $1.9 \times 10^{-12}(0.14)$ \\
\hline Styrenated polyester. pigmented & $1.7 \times 10^{-10}(13)$ & N.D. & N.D. \\
\hline
\end{tabular}

density*, however, the permeation coefficients oi the noble gases decrease with increasing gas molecular weight and diameter, as shown by our data and the data of Meares 2,3 .

It has been show $n^{8}$ that $P=D S$, where $P$ is the permeation coefficient, $D$ is the diffusion coefficient. and $S$ is the solubility coefficient, provided $D$ is constan1. Up to pressures of 1 or 2 atmospheres, the solubility of the noble gases in polymers obeys Hen.y's law, i.e. $C=S p$, where

$$
\begin{gathered}
\mathrm{C}=\text { concentration of gas dissolved in unit } \\
\text { volune of polymer }\left(\mathrm{cm}_{\mathrm{ST}}^{3} / \mathrm{cm}^{3}\right)
\end{gathered}
$$

$\mathrm{p}=$ partial pressure of noble gas in contact with the polymer (1 atm)

$$
\mathrm{s}=\text { solubility coefficient }\left(\frac{\mathrm{cm}_{\text {STP }}^{3}}{\mathrm{~cm}^{3} \cdot \mathrm{atm}}\right) \text {. }
$$

For gases that dissolve only sparingly, the solubility coefficient ( $S$; is a constant. Once dissolved the permirated molecules diffuse to the other side of the membrane. The driving force is the concentration

*The cohesive energy density (CED) is approximately equal to the heat of vaporization or sublimation at constant volume and can be estimated from thermodynamic data. difference that exists between the incoming and outgoing membrane surfaces. The flux of permeant (J) per unit membrane surface area is then given by

$$
\text { or } \begin{aligned}
T & =\mathrm{D}\left(\mathrm{C}_{\text {in }}-\mathrm{C}_{\mathrm{oui}}\right) / \mathrm{d} \\
\mathrm{J} & =\mathrm{SD}\left(\mathrm{p}_{\mathrm{in}}-\mathrm{P}_{\mathrm{out}} / \mathrm{d},\right. \\
\text { where } & =\text { thickness of the membrane }(\mathrm{cm}) \\
\mathrm{D} & =\text { diffusion coefficient }\left(\frac{\mathrm{cm}^{2}}{\mathrm{~s}}\right) \\
\therefore & =\text { flux of permeant }\left(\frac{\mathrm{cm}_{\mathrm{STP}}^{3}}{\mathrm{~s}-\mathrm{cm}^{2}}\right)
\end{aligned}
$$

The difiusion coefficient (D) is essentially a constant for sparingly soluble geses because the membrane structure is not perturbed by the dissolved molecules. Up to and near atmospheric pressures, the diffusion of noble gases in polymers is independent of concentration. This is mainly because of the very low concentrations encountered at all nurma' pressures, but it also reflects the comparative lack of interaction between these gases and the polymer.

At pressures of 1 or 2 atmospheres, the sulubility of the gases in the polymers obeys Henry's law. In 


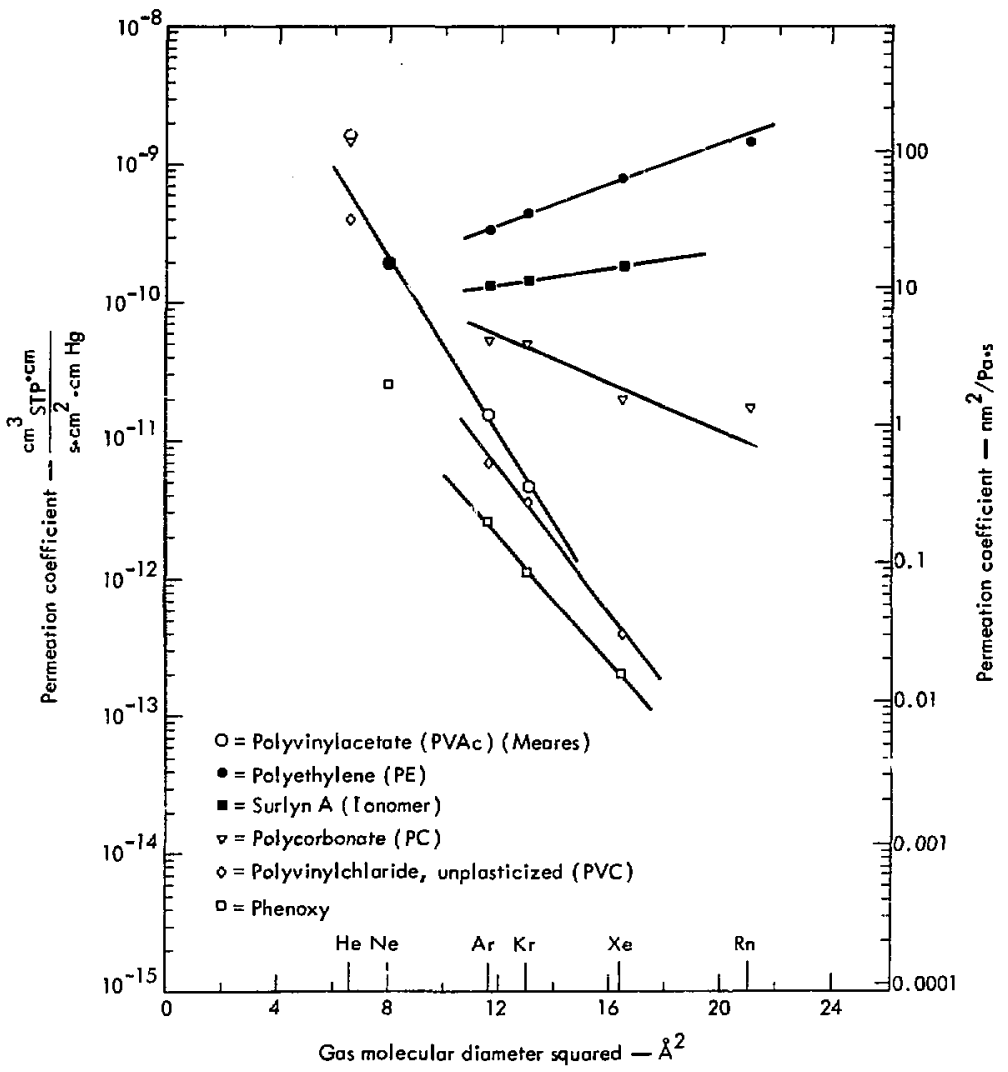

Fig. 2. Permeation coefricients of films vs the square of the gas molecular diameter. 


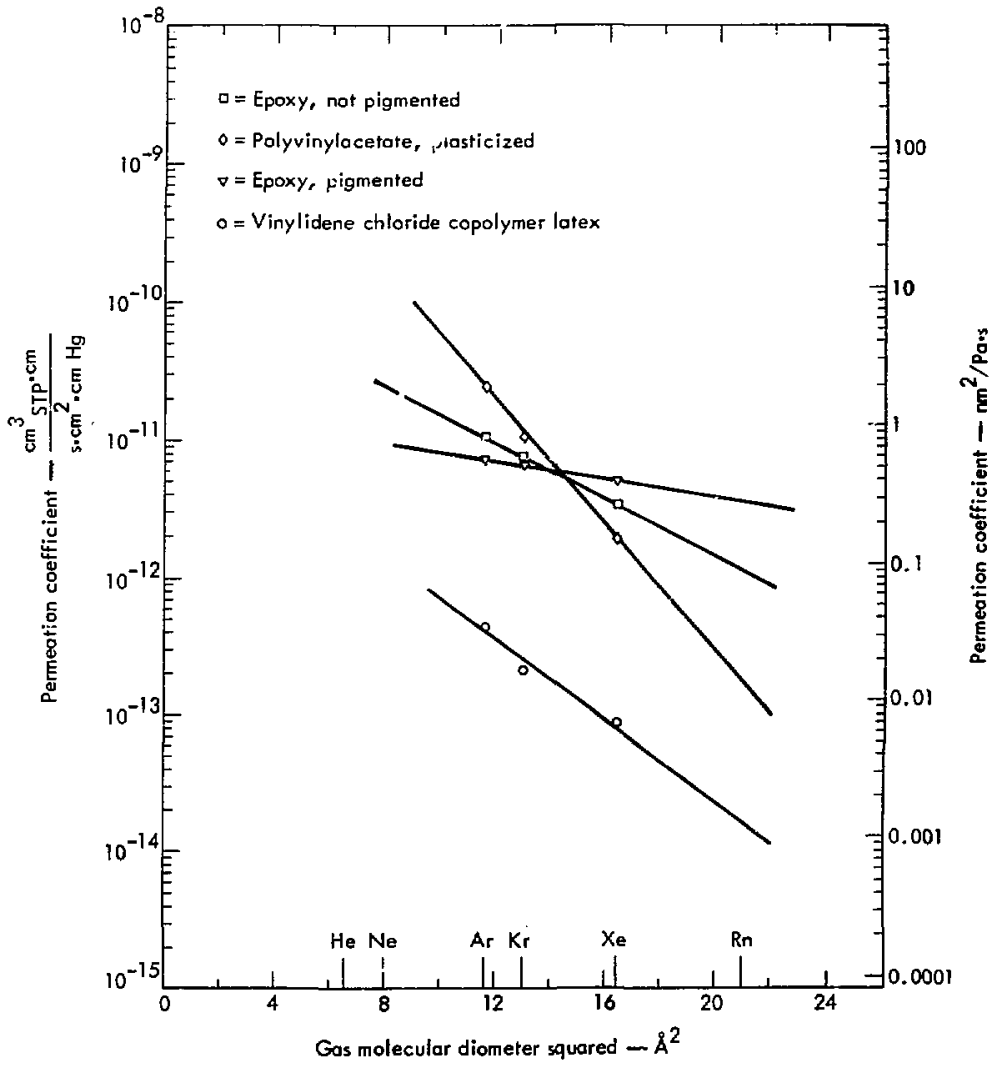

Fig. 3. Permeation coefficients of coatings vs the square of the gas molecular diameter. 
the generally accepted picture of the activated diffusion process, larger holes need to be formed in the polymer for the diffusion of larger molecules. These larger holes require a larger energy for their formation, thus the activation energy will be larger for the diffusion of larger molecules and the diffusivity will be smaller. This has been found to be true. However, the solubility increases with increasing gas molecular weight and has been shown ${ }^{9,10}$ to be directly related to the critical temperatures of the gas. Solubility of simple gases in hydrocarbon polymers has been found to be directly proportional to the volume fraction of amorphous polymer; ${ }^{11}$ however, introduction of polar groups decreases solubility. Thus, in looking at the permeability coefficients of the noble gases in a particular polymer film. if the solubility coefficient increases more (in going from one noble gas to the next in order of increasing molecular weight) than the diffusion ccefficient decreases, the net effect on the permeation coefficient is an increase.

\section{Modification of Coatings}

\section{Effects o Pigments in Coatings}

Miny of the coatings evaluated in this study were pigmented as obtained from the manufacturer. In zome cases, it was possible to compare piginented with non-pigmented coatings, but, as in the case of the epoxy coatings reported (compare the HydrEpoxy coatings with the EpiRez/LipiCure coatings) there appeared to be fittle difference belween them. It would be reasonable to expect. however. thal some pigments would reduce the permeability of the cuating by an overlapping or leafing structure in the dried coating. Two pigments were selected witl this elfect in mind: a teafing aluıninum pigment, and powdered mica. In a Saran latex (Duw XD-4624), the addition of the leafing aluminum pigment reduced the permeation coefficient by about a factor of 2 , but the mica modified coating had a permeation coefficient higher than the unmodified coating by about a factor of 10 . The pigments were also studied in an ethylene/viny1 chloride copolymer, Monflex 4514. The permeation coefficient to argon of the mica modified Monflex 4514 was found to be $1.2 \times 10^{-11}$, about inalf the value found for the latex compound with aluminum pigment, but still twice as high as the unpigmented latex. Because the permeability coefficients appeared to be affected more by the choice of the base polymer than by pigment compounding, this work was not carried further. Data are listed in Table 3.

\section{Effects of Crosslinking}

Crosslinking of polymer film has been shown to reduce permeation, apparently by reduction in the diffusion constant. ${ }^{12+15}$ No direct attempt was made in this program to reciuce permeation by crosslinking

Table 3. Effects of pigments in coatin ${ }_{\zeta}$.

\begin{tabular}{llll}
\hline Coating (type) & \multicolumn{1}{c}{ Pigment } & Permeation coefficient of coating \\
\hline & & $\frac{\mathrm{cm}_{\text {STP }}^{3} \mathrm{~cm}}{\mathrm{~s} \cdot \mathrm{cm}^{2} \cdot \mathrm{cr} \mathrm{rig}}$ & $\frac{\mathrm{nm}^{2}}{\mathrm{~Pa} \cdot \mathrm{s}}$ \\
Saran XD-4624 (Vinylidene chloride copolymer) & None & $4.4 \times 10^{-13}$ & 0.033 \\
Saran XD-4624 (Vinylidene chloride copolymer) & Leafing sluminum & $1.9 \times 10^{-13}$ & 0.014 \\
Saran XD-4024 (Vinylidene chloride copolymer) & Ground mica & $4.2 \times 10^{-12}$ & 0.32 \\
Monflex 4514 (ethylene/vinyl chlorice copolymer) & None & $6.0 \times 10^{-12}$ & 0.45 \\
Monflex 4514 (ethylene/vinyl chloride copolyures) & Leafing aluminum & $2.5 \times 10^{-11}$ & 1.9 \\
Monflex 4514 (ethylene/vinyl chloride copolymer) & Ground mica & $1.2 \times 10^{-11}$ & 0.9 \\
\hline
\end{tabular}


hecause of the difficulty of introducing crosslinking agents dhat would be effective in room temperature cures. However, we did obseres a definite lowering. by aboul an order of magnitude, in the permeation cuefficient of a HydrEpoxy coating that was retested after standing for several montlus. We attribute this to the increase in crosslinking taking place in the room temperature curing epoxy. A polyvinyl acetate coating prepared at the sime time as the epoxy coating showed no change on remeasurement aiter standing.

\section{Tlrickening Agents}

Sume of the coatings were low in viscosity and tended to sink into porous substrates such as the uranium ore. If this happened, a coherent film was not formed and the coating was not a good barrier. Thickening agents such as polyvinyl alcohol solution or carboxymethyl celltalose were recommended by the manufacturer. Lised at the recommended levels, these thickening agents did not change the permeation coefficients. However, the thickened coating made a coherent film when applied to uranium ore, and thus slould be a better barrier.

Correlation of Permeability with Polymer Structure

In selection of coatings as radon barriers, it would be desirable to be able to predict the radon permes. tiun coefficient based on the structure of the base polymer used in the coating. For this reason, we made some s.udies of possible relationships. Many cthemical, morphological, and structural properties of the polymer can affect the permeability of a poly. mer! $4,16-1$ t These include chemical properties such as cuhesive energy density (CED) and hydrogen bond. ing, morphological properties such as crystallinity and orientation, and the effect of structural gruups in the polymer chain. It was quickly apparent that ClD alsne would not correlale with perniesbility. bul we did find a ressonable currelstion of the produit of CED and polymer density with argun peruresbility. as shown in Fig. 4. This courclation did not appear to liuld will the hitglict molectular weight noble gases. We then tried lincar repression analysis with a number

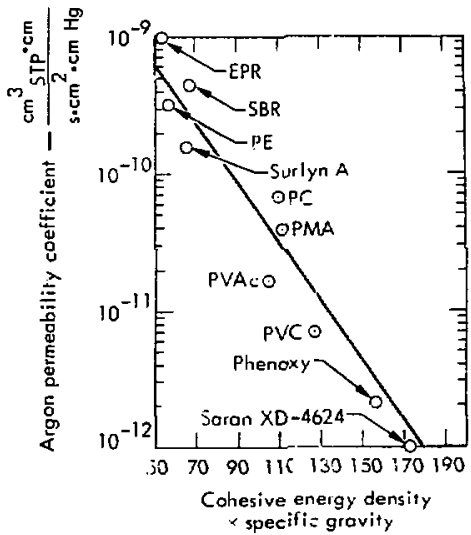

Fig. 4. Argon pertneability coefficient vs cohesive energy density times specific gravity.

of polymer properties including CED. density. refrattive index. gus molecular diameter (d), $d^{2}$, etc. The results were nut particularly promising- We observed, lowever. that there was a currelation of the argon permeability of a number of polymers with the oxygen Permachor as developed by Salame ${ }^{19}$ (see Fig. 5).

This relationslip was later extended to the other noble gases. Althougl: Salame developed the Permachot equation enpirically. he showed that there was a definite relationship to the classical relationship betwetn permeability. dıffusiun, solubility. and temperature:

$$
P=D S=\left\langle D_{0} S_{0}\right)=-\left[\left(E_{\downarrow}+\Delta H\right) R T\right]_{\text {see Ref. } 8\} .}
$$

where

$$
\begin{aligned}
& P=\text { petireability coefficient } \\
& \mathrm{V}=\text { diffusion cocfficient } \\
& S \text { a solubility coefficient } \\
& E_{d} \text { a cneray of diffusion } \\
& \Delta \mathrm{I} \text { a heat of solution of the gas in the polynet. }
\end{aligned}
$$




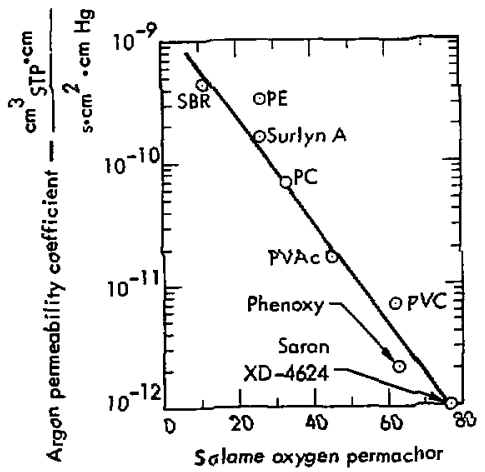

Fig. 5. Argon permeability coeffitient vs Solane oxygen Pennachor.

$D_{0}$ and $S_{0}$ are pre-exponential factors from the Arrhenius equations $\mathbf{R}$ is the gas constant and $T$ is absolute ter.perature.

Salame's Permachor equation for the oxygen permeability of polymers at $25^{\circ} \mathrm{C}$ is: $\mathrm{P}=\left(6.1 \times 10^{-9}\right) \mathrm{e}$ $0.115 \mathrm{I}$, where $\mathrm{I}$ is the oxygen Permachor. The

Permachor equation carl also be written

$$
P=e^{-0.115 I} e^{-(11200 / R T)},
$$

which can be written in the form

$$
P=e^{A+B I} \text { or } \ln P=A+B I \text {. }
$$

where $\Lambda$ can be related to $\left(E_{d}+\Delta H\right) / R T$, and the coefficient $B$ is determined by fitting experimenta] data.

We have studied the permeability of the noble gases, especially argon, krypton, and xenon, and have found that a relationshin exists between the factors $A$ and $B$ and the squarc it it: ans molecular diameters. Apparently it is, ivissible to extrapolate to radon permeability through the determination of inese relation. ships.
Because the data were limited to Ar, Kr, and $\mathrm{Xe}$, a linear relationship was used. A least-squares fit was made of the uxygen Permachor to the permeability data we had determined for phenoxy, polyvinyl illoride, polycarbonate, polyethy tene ionomer (Surlyn A), and Meares ${ }^{2.3}$ data for polyvinyl acetate. The coefricients $A$ and $B$ of the gases argon, krypton, and xenon thus obtained appeared to be linearly selated to the $\mathrm{d}^{2}$ of the gases. The least squares fit of this relationship resulted in the tinal equation

$$
\begin{gathered}
\text { In }\left(10^{2} P\right)=\left(4.2354+0.4165 d^{2}\right)+ \\
\left(0.088-0.0155 d^{2}\right) 1,
\end{gathered}
$$

where $\mathbf{P}=$ permeability coefficient in $\mathrm{nm}^{2} / \mathrm{Pa} \cdot \mathrm{s}$

$$
\begin{aligned}
& d^{2}=\text { gas diameter squared, in } A^{2} \\
& \mathrm{l}=\text { Salame's oxygen Permachor. }
\end{aligned}
$$

Calculated values, using this equation, are shown in Table 4 along with our experimentally determined values for is tumber of polymers and coatings. The fit is quile good in most cases, but is rather poor for polyethylene. Because the Permuchor is related to the structure of the polymer, this equation establishes is definite relationship to polymer structure and can be used to estimate the permeability of radon as well as the other noble gases through pulymers.

There are relatively lew permeability data in the iitarature for the noble gases as the major interest is in nitrogen, oxygen, carbon dioxide, and water as they nay affect packaging of foods, etc. However, Burgess $c^{\prime} d l^{20}$ have measured the permeability of polymethyl acrylate to argon and krypton and reported values equivalent to 1.3 and $0.75 \mathrm{~nm}^{2} / \mathrm{Pa} \cdot \mathrm{s}$ at $20^{\circ} \mathrm{C}$. The oxygen Permachor of polymethyl acrylate calculated from Salame's segmental values is 51. Using this value in the above $:$ quation, we calculate values for argon and kryptun of 0.8 and 0.48 $\mathrm{nm}^{2} / \mathbf{P a}$ s, which agree to belter than a factor of 2 with the experimentally determined values.

tSalame used the symbol $\pi$ (pi) for Permachor. We use I to avoid confusion with the conventional use of $\pi$. 
Tahle 4. Permeability coefficients of polymers calculated from Permachor."

\begin{tabular}{|c|c|c|c|c|c|c|c|}
\hline \multirow[t]{2}{*}{ Material } & \multirow{2}{*}{$\begin{array}{c}\text { Permachor } \\
\text { (l) }\end{array}$} & & \multicolumn{5}{|c|}{ Permeability, $\mathrm{nm}^{2} / \mathrm{Pa}$ : $\mathrm{s}$} \\
\hline & & & $\mathrm{Ne}$ & Ar & $\mathrm{Kr}_{\mathbf{r}}$ & $\mathrm{Xe}$ & $\mathbf{R n}$ \\
\hline \multirow[t]{2}{*}{ Phenoxy film } & 63 & Experimental & 1.9 & 0.20 & 0.08 & 0.016 & - \\
\hline & & Calculated & 2.0 & 0.27 & 0.12 & 0.02 & 0.0015 \\
\hline \multirow{2}{*}{$\begin{array}{l}\text { Polyvinyl chloride film, } \\
\text { unplasticized }\end{array}$} & 62 & & - & 0.53 & 0.26 & 0.03 & - \\
\hline & & & 2.1 & 0.29 & 0.14 & 0.02 & 0.0019 \\
\hline \multirow[t]{2}{*}{ Polycarbonate filın } & 33 & & - & 4.1 & 3.8 & 1.5 & 1.4 \\
\hline & & & 5.9 & 4.2 & 3.7 & 2.7 & 1.7 \\
\hline \multirow{2}{*}{ Surlyn A film } & 26 & & 15 & 9.8 & 11 & 14 & - \\
\hline & & & 7.6 & 7.8 & 8.1 & 8.5 & 9.1 \\
\hline \multirow[t]{2}{*}{ Polyvinyl acetate (data of Meares) } & 45 & & 15 & 1.1 & 0.36 & - & - \\
\hline & & & 3.8 & 1.4 & 0.94 & 0.36 & 0.10 \\
\hline \multirow[t]{2}{*}{ Epoxy, pigmented coating ${ }^{b}$} & 50 & & - & 0.55 & 0.51 & 0.38 & - \\
\hline & & & 3.2 & 0.88 & 0.53 & 0.16 & 0.03 \\
\hline \multirow[t]{2}{*}{ Epoxy, unpigmented coating ${ }^{c}$} & 55 & & 3.4 & 0.83 & 0.58 & 0.26 & - \\
\hline & & & 2.7 & 0.56 & 0.30 & 0.07 & 0.001 \\
\hline \multirow{2}{*}{$\begin{array}{l}\text { Polyvinyl acetate, }{ }^{d} \text { plasticize } \\
\text { coating }\end{array}$} & 43 & & - & 1.8 & 0.83 & 0.14 & - \\
\hline & & & 4.1 & 1.7 & 1.2 & 0.50 & 0.16 \\
\hline \multirow[t]{2}{*}{ Polyethylene film } & 26 & & - & 25 & 34 & 60 & 113 \\
\hline & & & 7 & 7.8 & 8.1 & 8.5 & 31 \\
\hline \multicolumn{3}{|l|}{$d^{2}, A^{2}$} & 8.0 & 11.6 & 13 & 16.4 & 20.9 \\
\hline \multicolumn{8}{|c|}{${ }^{a} \operatorname{Rn}\left(10^{2} P\right)=\left(4.2354+0.4166 d^{2}\right)+\left(0.0880-0.0155 d^{2}\right) 1$} \\
\hline \multicolumn{8}{|c|}{${ }^{6}$ Permachor estimated and arbitrarily lowered for pigment content. } \\
\hline \multicolumn{8}{|c|}{ 'Permachor estimated. } \\
\hline \multicolumn{8}{|c|}{${ }^{\mathrm{d}}$ Permachor arbitrarily lowered for plasticizer content. } \\
\hline
\end{tabular}


Permeability of Uranium Or:

The permeability was measured in a sample of uranium ore supplied by USBM. The ore sample was retrieved from the Dakota Mine located 29 miles northwest of Grants, New Mexico. The exact location within the mine was 657 ft from the portal. The change in sample permeability with confining pressure up to 800 psi was also measured. This pressure corresponds to approximately $800 \mathrm{ft}$ of overburden.

Sample preparation was fairly standard. Several cored specimens were machined to the desired dimensioris and at tached to enc udaptors for abing connections. Confining oil pressure was exerted on a sample in both the radial and axial directions. Oil pressure was transmitted without penelration througl a flexible plastic jacket cast around each simple. Stendy state. axial flow of dry $\mathrm{N}_{2}$ gas through the sample provided the conditions required for permeability determination.

The results of the measurements are sunnmarized in Table 5.

Based on thise medsurements, ore permejbility in the uncinfined state ranges from 0.25 to 0.46 darcys, decreasing al mosi $25 \%$ at 800 psi confining pressure. Since the simples were oven dried at 50 to $60^{\circ} \mathrm{C}$ prior to the medsureinents, the above values represent the upper limit of permedbility. and would be greatly reduced wish the presente of interstitial water.
The permeibility of rock is norm.lly reported in darcys. but this can be converted into the units we have been using by introducing the appropriate gas viscosity value and the appropriate pressure currection. For argon gas, the viscosity is $222 \times 10^{-6}$ poise $(222 \times$ $\left.10^{-7} \mathrm{~Pa} \cdot \mathrm{s}\right)$. To convert darcys to $\left[\left(\mathrm{cm}^{3} \cdot \mathrm{cm}\right) /\left(\mathrm{s}^{-} \mathrm{cm}^{2}{ }^{2}\right.\right.$. $\mathrm{cm} \mathrm{Hg)}$. divide dircys by about 1.7. To convert darcys to $\left(\mathrm{nm}^{2} / \mathrm{Pa} \cdot \mathrm{s}\right)$. multiply darcys by $4.4 \times 10^{10}$. Thus, 0.25 darcy equals $0.15\left[\left(\mathrm{~cm}^{3} \cdot \mathrm{cm}\right) /\left(\mathrm{s}^{*} \mathrm{~cm}^{2} \cdot \mathrm{cm}\right.\right.$ $\mathrm{Hg})]$ or $1.1 \times 10^{10}\left(\mathrm{~nm}^{2} / \mathrm{Pa} \cdot \mathrm{s}\right)$.

\section{TASK 3: EVALUATION OF TOXICITY OF COATINGS}

Coatings suitable for use in a mine should be nonfoxic s.turing application. and the combustion and pyrolysis products should be of low toxicity. The volatile components of the coatings materials were identified qualitatively and semiqualitatively using gas chromatography and mass spectrography (GC/MS). The combustion and pyrolysis products were evaluated in two separate sludies: (1) on cement-asbeste: board specimens in the 1.LL-NBS Smoke Chamber, and (2) stnall scule pyroly sis studies of unsupported fums of the coutings. Finally, toxicological evaluations were Inade of the data from these studies from published toxitological information: no animal toxicity studies were inade.

Table S. Permeability of usanium ore somples at 0 to 800 psi confining pressure.

Confuning pressure, psis

\begin{tabular}{|c|c|c|c|}
\hline & Samuple 1 & Sample 2 & Sample 3 \\
\hline $\mathbf{0}$ & 0.25 & 0.29 & 0.46 \\
\hline 102 & 0.25 & 0.28 & 0.46 \\
\hline 200 & 0.25 & 0.27 & 0.46 \\
\hline 400 & 0.34 & 0.25 & 0.46 \\
\hline 600 & 0.24 & 0.23 & 0.46 \\
\hline 800 & 0.24 & 0.21 & 0.45 \\
\hline
\end{tabular}


Snuke Chamber Studies ol Coutings

\section{Preparation of Snccimens}

Tine toatings were lested on centent-asbestos board substrates about $73 \times 73 \times 25 \mathrm{~mm}$ : the area exposed to heal and flame is about $65 \times 65 \mathrm{~mm}$. Thermo. couples were imbedded at the center surface and at the lower surface, $0 \mathrm{~mm}$ from the lower edge. The lower thermocouple was impinged by the flame in the eurly tests (HydrEpoxy 300, Saran XD-71 51. Ess:X polyester, and Ventron's Resitron I1), but due to a slight modification of the smokc chamber, the thermocouple was slightly out of the flame area in the later tests. Some tests were also made on similar sized test specimens cut from uranium ore. There was no significont difference in the test results, and because use of uranium ore in the smoke chamber urea required close monitoring by Hazard Control personnel (concern about release of alpha radiation), most tests were made on cement-asbastos board substrates only.

The coatings were prepared on the substrate usually by spraying, but sometimes by doctoring the coating material. It wiss usually necessary to use multiple coating to reach the desired coating thickness of 0.010 in. $(0.25 \mathrm{~mm})$. Although most cuatings were tested at this thickness, the Resitron 11 coatings were 0.015 and 0.020 in. thisk $(0.38$ and $0.51 \mathrm{~mm})$, and the Hydro Seal costings were only 0.007 and 0.008 in. thick ( 0.18 to $0.20 \mathrm{~mm}$ ) and the Hydro Seal did not spread uniformly (did not wet) the previously dried coating.

\section{Snoke Chanber Tesis}

This test studies the time dependence of toxic gas evolution under conditions designed to simulate 9 "fire" exposure, We used the LLL version of the NBS. developed Smoke Density Chamber. The procedure is given in NBS Teclinical Note 708 and was also desribed in the literature. $?$

In this test, the specimen is exposed to a radiant heat flux of $2.5 \mathrm{~W} / \mathrm{cm}^{2}$. (a) without the presence of an igniting flame (NF in tables and figures). and (b) in the presente of a small igniting flame ( $F$ in tables and figures). Tise rudiant lieat nux of $2.5 \mathrm{~W} / \mathrm{cm}^{2}$ is equiva. lent to that emitted by a black body at a temperature of $527^{\circ} \mathrm{C}\left(980^{\circ} \mathrm{F}\right)$. This is considered to be i moderately sovere fire exposure. The clumber is continually monitored for smoke density. $\mathrm{CO}$. and $\mathrm{CO}_{2}$ content. The LLL chamber is also fitied with a continuous sampling device to measure $\mathrm{HC}$ : this was used in the case of the Saran XD-7151 coatinis tests. The results. however, were lower than expected, based on the results of our sm:all scale pyrolysis tests. We now believe these $\mathrm{HCl}$ values from the smoke thamber tests to be invalid; they are low due to absorption on the chamber walls and sampling tubes, as well as incomplete recovery of $\mathrm{HCQ}$ from the chamber gas.

The data from the smoke chanber tests are listed in detuil in Table A-2 and Figs. A-1 to A-15 in Appen$\operatorname{dix} A$. The results may be summarized as follows:

I. HydrEpoxy 300, a vater-based, pigmented epoxy coating. Under non-llaming conditions, the coating slowly produced a fight smoke over a 30-min period, without any detectable production of $\mathrm{CO}$ or $\mathrm{CO}_{2}$. Under flaming conditions, a light smoke was produced with an accompanying $\epsilon$ rolution of both $\mathrm{CO}$ $(350 \mathrm{ppm})$ and $\mathrm{CO}_{2}(1.4 \%)$. This amount of $\mathrm{CO}_{2}$ is due to the pilot flame used under flame conditions. The quantities of thess gases are similar to those found for other epoxy coatings previously tested in the same manner.

2. Saran XD-7151, a vinylidene chloride copoly. mer latex. Very little if any smoke was evolved from these cuatings under either flaming or non-flaning conditions. No $\mathrm{CO}_{2}$ was detected under non.flaming exposure. Under the flaming condition, the concentration of $\mathrm{CO}_{2}$ reuched about $1.4 \%$ in about $30 \mathrm{~min}$, about the same as that for uncoated samples. We astribe this to the combustion of the pilot flame. The Saran coating yielded $50 \mathrm{ppm}$ CO in 25 min under a nonflaming condition and 300 to $500 \mathrm{ppm}$ in 25 min under the flaming expostre. As inditated abovi, the HCR values are low.

3. Essex Polyester. a one-conponent (internally catalyced, initiated by atmospheric moisture) styrenated polyester. This muterial slowly evolved a light smoke under the non-flaning exposure and a slightly denser smoke ander the flaming exposure. Essentially no $\mathrm{CO}$ or 
$\mathrm{CO}_{2}$ was evolved under non-flaming exposure. In the flaming case a slow evolution of $\mathrm{CO}$ was observed with a maximum of 70 ppin in 30 min. Likewise a small amount of $\mathrm{CO}_{2}$ was slowly evolved up to a maximum of $1.5 \% \mathrm{ct}$ 30 inin; most of this can be ascribed to the pilot flante.

4. Resitrc.. 1I, a catalyzed furfuryl :llohol polymer coating. This coating gave off no smoke under the non-flanning cundition anci a very light snoke under the flaming mode. Essentially no $\mathrm{CO}$ or $\mathrm{CO}_{2}$ was evulved under non-flanting exposure. In the flaming mode, a slow evolution of $\mathrm{CO}$ was observed with a maximum of $100 \mathrm{ppm}$ in 30 min. The $\mathrm{CO}_{2}$ was evolved slowly up to a maximum of $1.5 \%$ at $30 \mathrm{~min}$, most of which can be ascribed to the pilot flame.

5. WSU-118, a low viscosity modified epoxy developed for Bureau of Mines by Washington State University. The coating slowly evolved a dense smoke under non-flaming exposure; under laming exposure a dense smoke was evolved moderately rapidly. No $\mathrm{CO}$ was detected under non-flaming expusure; under naming exposure, a maximum of $300 \mathrm{ppm}$ was evolved.

6. Aerospray 70 , a polyvinyl acetale latex containing dibutyl phthalate plusticizer. Under both non-flaming and flaming exposure, the coating evolved a dense sinoke moderately rapidly. No $\mathrm{CO}$ was detected under nonflaming exposure; under flaming exposure a maximum of $200 \mathrm{ppm}$ was evolved.

7. EpiRez WD-510/EpiCure 872, a waterdispersed polyamine-cured epoxy coating. This was also evaluated cured with a blend of EpiCure 872 and 879: this cures harder and faster. Dense smoke evolved under both flaming and non-flaming conditions; evolution was slower under the non-flaming condj. tion. No $\mathrm{CO}$ tras detected under non-1laning condition; flaming exposure produced a maximum of $300 \mathrm{rpm}$.

8. Promulsion 200 , in unidentified pigmented emulsion. This slowly produced a moderately dense smoke under llun-flaming exposure: under flaning exposure it produced a some. what denser smoke more rapidly. In the latter Lase transient ignition and flame extinction occurred throughout the test. No CO was detected under the non-flaming consition and only a minimal amount, 25 ppm, was detected under nianing exposure.

9. Hydro Seal, a water-based acrylic sealer, unpigmented. This slowly produced a modexste smoke in the non-flaming mode; in the flaming condition no ignition occurred, although a slightly denser smoke was produced. and a bit more rapidly. No $\mathrm{CO}$ was detected under either condition.

Sinoke density curves. the specific optical density versus time, for several of the coatings are plotted in Fig. 6. Resitron Il evolved a viry light smoke and its specific optical density did not reach the valu' of 16 . which is considered severe visual obscuration for a firefighter wearing a mask or other protective equipment. HydrEpoxy 300 produced a light smoke, with little difference on the transite substrate under flaming (F) or non-flaming (NF) conditions. Essex Polyester, also a light smoker, prodt:eed a slightly denser smoke more rapidly in the flaning mude. The EpiRez WD-5 10/EpiCure 872 coating evulved a Jense smoke rapidly, especially in the flarning mode.

\section{Flash Points of Coatings}

Coatings materials for use in mines must have relatively high flasli points to avoid danger of fire and explosion during application. The seven coalings selected for detaila i evaluation were tested for flash point by the closed cup method (ASTM D.56). These coatings were: Acme's HydrEpoxy 300, Dow's Saran XD-7151, Ventron's Resitron II, Essex's styrenated polyester, Bureau of Mine's WSU-1 18. Cyananid's Aerospray 70, and Celanese's EpiRez WD.510/EpiCure 872. Except for Essex's styrenated polyester, none of the coatings systems had a measurable flash point under the conditions of the test. i.e. less than $79^{\circ} \mathrm{C}$ $\left(175^{\circ} \mathrm{F}\right)$.

The Essex Polyester had a closed cup flash point (ASTM D-56) of $20^{\circ} \mathrm{C}\left(68^{\circ} \mathrm{F}\right)$, and an open cup lash 


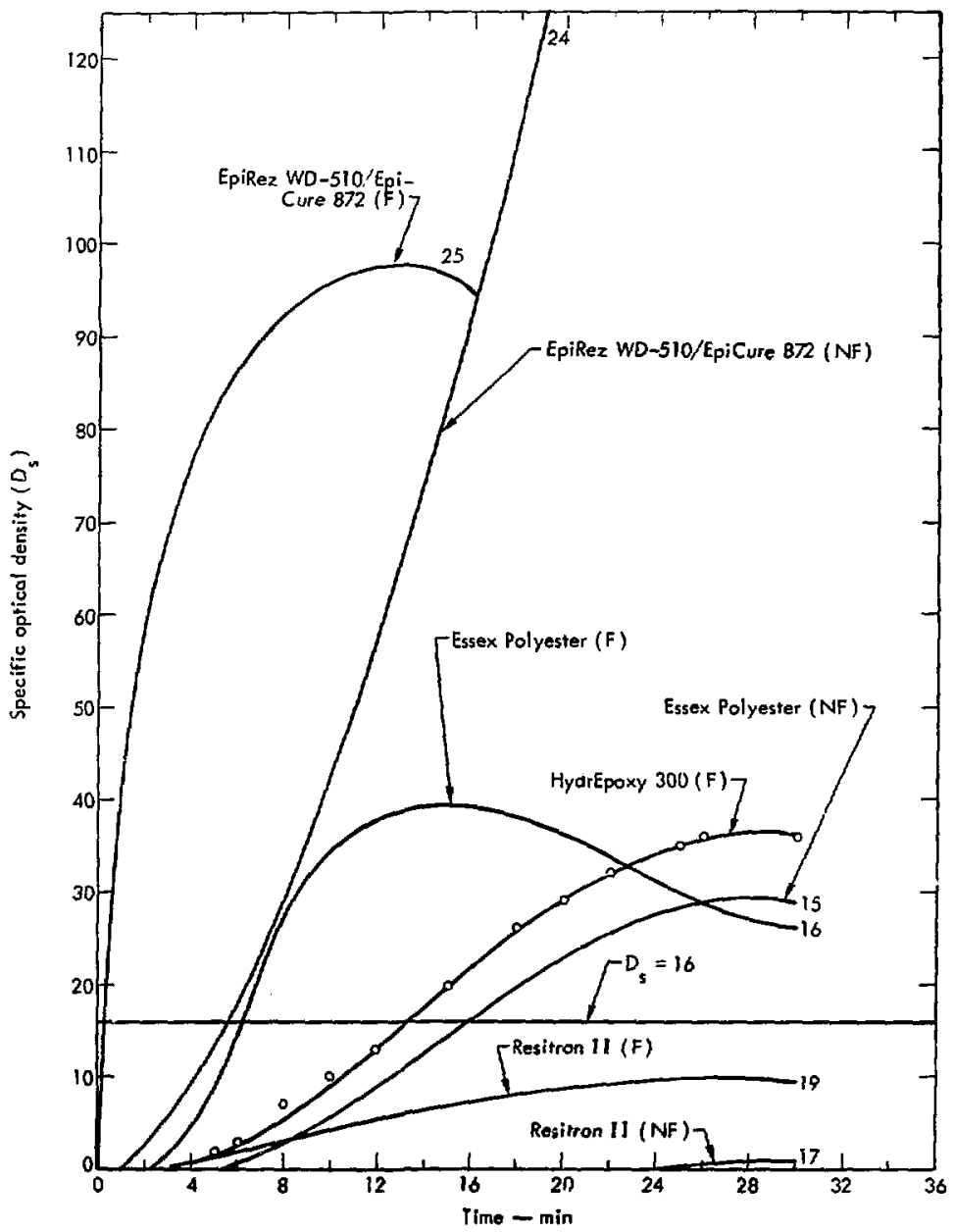

Fig 6. Smoke density curves for some representative coatings. 
point (ASTM D.1310) of $39^{\circ} \mathrm{C}\left(102^{\circ} \mathrm{F}\right)$. This latter value is somewhat higher than the literature value ${ }^{22}$ for styrene of $31^{\circ} \mathrm{C}$, but may be due to the fact that the material tends 10 "skin over" rapidly, su nust be stirred occusionally during the test.

\section{Laboratury Pyrolysis Test Under Non-Flaming Conditions}

In this section the pyrolysis data for seven selected polyner systems are summarized. It shoutd be noted that our objectives were to detormine iti a semiqualititive way the extent of toxic yas evolution and to compare the results for the differen! polymer systems.

The gas concentration dat a were obtained from small-scale laboratory experiments under non-thurning conditions. Samples, weighing between 25 and $75 \mathrm{mg}$, were isothermally heated in closed guartz tubes with a free volume of about 0.13 litre. The samples were pyrolyzed in normal laboratory air ${ }^{*}$ at temperatures ranging from 200 to $600^{\circ} \mathrm{C}$. Reaction times varied between 0.25 and $4 \mathrm{~h}$. The longer reaction times were used at temperatures below $300^{\circ} \mathrm{C}$ to achieve a measurable degree of degradation. For each polymer system at least nine separate pyrolysis tests were made. In each test the experimental variables (tine. temperature, and initial weight and/or film surface area of the sample) were vuried to sample the ininnite popula. tion of measurements.

At the tompletion of each pyrolysis experiment the gases were analyzed by mass spectroscopy (MS). For the Sarin polymer two identical pyrolysis tests were done: one to obtain the gus analysis by MS: the second for the analysis of HCl. Hydrochloric acid was determined by dissolving the gaseous and absorbed $\mathrm{HCl}$ with dilute base followed by titration of the chloride ion. Selected gas mixtures, which were previously analyzed by MS. were also analyzed by gas chromatography (GC) to detect low level pyrolysis products. Standard gas mixtures contuining $\mathrm{CH}_{4}$. $\mathrm{C}_{2} \mathrm{H}_{6}$, and $\mathrm{CO}_{2}$ were used to culibrate the chromato. graph. The $\mathrm{CO}$ concentration is accuratcly determined

-The tubes were filled with air at atnospheris: pressure; the relative humidity was about $40-50 \%$. by MS. Worst condition detection limit is about $0.3 \%$. With a ther nial conductivity deteitor the timit of detertion for these gases was about 75 ppm. The results of the $\mathrm{CC}$ work (I) verified tlie presence and approximale cioncentration of the gases as meisured hy MS and. (2) showed that no other co sponents were present at concentistions abuve 75 ppm.

\section{Results and Discuss..}

This discussion will be inainly concen ed with three topics: (1) HCl production from Saran; /2) Comparison of polymer stability and gas evolution data; (3) Conparison of $\mathrm{CO}$ evolution data from laboratory and smoke chamber tests.

HCe Production from Saran - It has previously been pointed out that the analytical system for determining HCQ during snoke chanber lest 5 is unreliable. In these tests most of the $\mathrm{HCl}$ appears to hav been lost by adsorption on smoke particle" or by dissolution in water vapor. Thus. the HCl aasd from the sinall scale laboratory tests (Table 1) are the only reliable data that can be used to prediet the evolution of this gas. These data indicate that the HCl evolution is essentially timedependent arter $15 \mathrm{~min}$ und temperature-independent between 300 and $800^{\circ} \mathrm{C}$. The best value appears to be the average of the 11 runs made under these conditions which is $0.26 \pm 0.07 \mathrm{cni}_{\mathrm{STP}}^{3}$ HCl (gas) per $\mathrm{mig}$ of sample weight.

Comparison of Polymer Stability and Gas Evolution Data - In Fig. 7 the percent weight loss is plotted as a function of temperature for each polymer system. The use of somewhat longer reaction times at temperatures below $300^{\circ} \mathrm{C}$ relati: $:$ to the reaction times used at the hightr temperature distorts the ph i somewlat. In effect the Iow temperature degradation is weighted mure than the degradation at the higher temperatuie. However, at each temperature the data sre comparable. Figure 7 clearly shows that Ventron's Resitron Il, Essex Polyester, and HydrEpoxy 300 have significantly better thermal rability than the other polymer systems.

The evolved $\mathrm{CO}$ and $\mathrm{CO}_{2}$ gas volumes as function of pyrolysis temperature are presented in Figs. A-16 


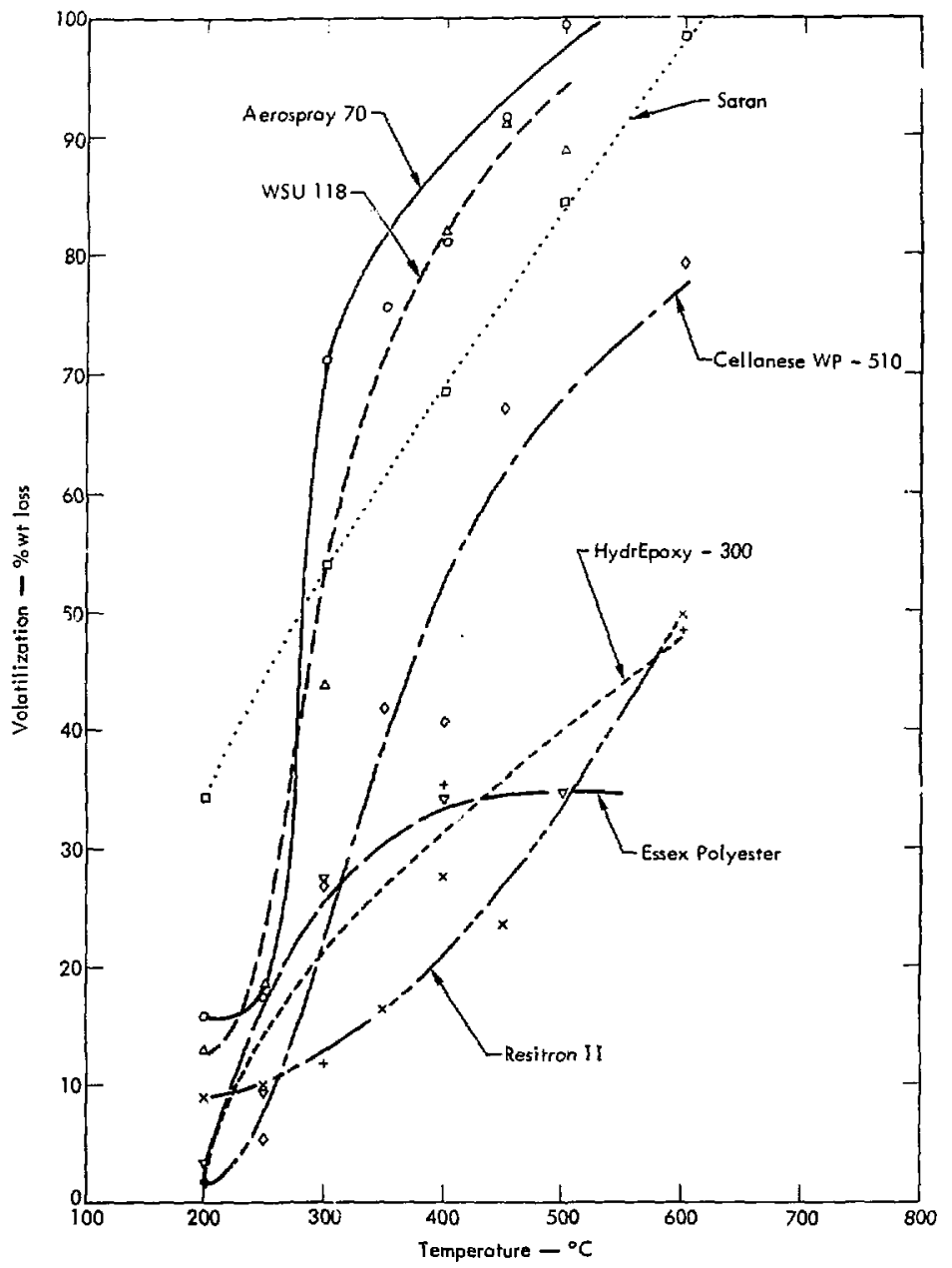

Fig. 7. Weight loss vs temperature. 
and A-17, respectively." A generislized CO evolution is shown in Fig. 8. The CO evolution for most coalings falls within the band. The Essex Polyester and Resitron show nuch different behavior. The gas volumes have been normalized to the initial sample weight $\left(W_{0}\right)$. Under isothermal conditions, and in the presence of oxygen, the effect of increasing the reaction time is to decrease the CO production rate. In the case of Saran, where the largest number oi data points were obtained, it appears that the $\mathrm{CO}$ evolution rate decreases as $t^{1 / 2}$. This is consistent with a rate controlled by a diffusion process. Our samples were films of nonuniform thickness, but generally of thick. ness larger than 10 mils. It is not unreasonable to postulate that the diffusion of oxygen into the film is the rate-controlling step, and that the reaction products ( $\mathrm{CO}$ and $\mathrm{CO}_{2}$ ) must diffuse out of the film. Figures 7 and A-16 also indicate that the gas evolution has an exponential temperature dependence. These facts lead us to postulate the following reaction rate expression for relatively thick Sarin fi]lns:

$$
\frac{d C_{C O}}{d t}=K e^{+t_{d} / R T} \rho_{\frac{A}{L}}^{A} t^{-h t},
$$

where

$$
\begin{aligned}
& K=\text { Consiant } \\
& E_{\mathbf{a}}=\text { The apparent activation energy } \\
& T=\text { Temperalure in } K \\
& A=\text { Surface area of the film } \\
& L=\text { Film thickness } \\
& R=\text { Gas constunt } \\
& \rho=\text { Film density }
\end{aligned}
$$

Similar rate expressions can be fitted to the other polymer systems.

Of principal interest in this study is the cvolution of the higlaly toxic gals. tarbon monoxide. Other potentially harmiful gases, such as hydrocarbons and hydrogen, were atso produced but at signifiteantly

\section{- Datla cubtuined from runs above $500^{\circ} \mathrm{C}$ have been} ontilled from these graphs because in nearly all cases the axygers depletion was near 100\%. Under this condition the combustion mechanism must be expected to differ from the condition with high oxygen concentration.

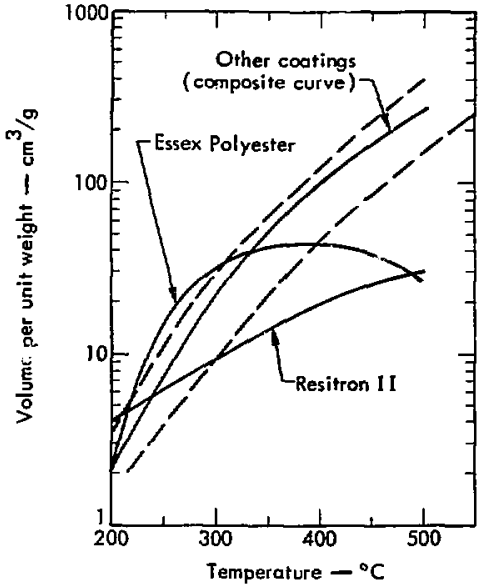

Fig. 8. Carbon monoxide evolution.

lower levels. Bused on the slopes of the CO-evolution curves (Fig. A-16) in the 300 to $500^{\circ} \mathrm{C}$ teini erature interval the seven polymers are ranked as follows:

Best: Ventron's Resitron

\section{Essex Polyester}

HydrEpoxy 300

Saran (considering the HCl data in addition to the $\mathrm{CO}$ data)

Aerospray 70

WSU. 118

Ep̣iR'z WD-510/EpiCure 872

These results are in general agreement with our conclusions obtained from the thermal stability data (Fìg. 7).

For the degradation below $300^{\circ} \mathrm{C}$ this ranking may not be quite correct. Materials with low activation energies, such as Ventron's Resitron II and Essex Polyester, produce relatively more $\mathrm{CO}$ at these low temperatures than the other polymers. 
Cemparison of $\mathrm{CO}$ Gas Evolution Datu from Laboratory and Smoke Chamber Tests - Smoke thamber tests were conducted under both flaming and non-flaning conditions. In the latter siturtion only the themal flux from the keater produces the polymer degradation. This situation is comparable to the small-scale laboratory tests. In contrast to the laboratory tests, no $\mathrm{CO}$ was detected in the smoke chamber studies (non-flaming mode), except for Siran ( $250 \mathrm{ppm}$ ).

In art attempt to predict the $\mathbf{C O}$ concentration fir $n$ the laboratory tests we make the following assumptions:

a) The average temperature of the polymer film was either $300^{\circ} \mathrm{C}$ or $250^{\circ} \mathrm{C}$ for $0.5 \mathrm{~h}$.

b) The film was uniformly heated (no nane).

c) The film thickness was uniform in both test situations and equal to $0.025 \mathrm{~cm}$ ( $10 \mathrm{mil})$.

These assumptions are expected to yield results that are upper limits for the predicted $\mathrm{CO}$ concentrations. ${ }^{*}$

The formula used to make these predictions is:

$$
\mathrm{Co}_{\mathrm{SC}}(\mathrm{ppm})=10^{6} \times \frac{V_{L}^{C O}}{V_{S C}} \times \frac{A_{S C}}{A_{L}} \times \frac{t_{S C}}{t_{L}},
$$

where

$$
\begin{aligned}
& \mathrm{CO}_{\mathrm{SC}}= \text { predicted } \mathrm{CO} \text { concentration in the smoke } \\
& \text { chamber }(\mathrm{SC}) \\
& \mathrm{v}_{\mathrm{L}}^{\mathrm{CO}}=\text { volume of } \mathrm{CO}\left(\mathrm{cm}_{\mathrm{STP}}^{3}\right) \text { ineasured in } \\
& \text { laboratory test }(\mathrm{L}) \text { at } 300^{\circ} \mathrm{C} \text { or } 250^{\circ} \mathrm{C} \\
& \mathrm{A} \quad=\text { fim surface area } \\
& \mathrm{t} \quad=\text { reaction time. }
\end{aligned}
$$

The laboratory data was taken from Tables A-2 through A-8: $A_{S C}=42 \mathrm{~cm}^{2}: V_{S C} \sim 5 \times 10^{5} \mathrm{~cm}^{3}$, $t_{S C}=0.5 \mathrm{~b}$. The predicted $C O$ concentrations, based on the $250^{\circ} \mathrm{C}$ and $300^{\circ} \mathrm{C}$ laboratory results are sum. marized in Table 6.

The predicted $\mathrm{CO}$ concentrations are below the minimum detectable level of the $\mathrm{CO}$ analyzer on the smoke chamber (25 ppm).

*For example, thermocouple measurements indicate that the film surface reaches about $300^{\circ} \mathrm{C}$ atter $0.5 \mathrm{~h}$. For most of the time the film surface is at a lower temperature where the degradation is proceeding at a slower rate.
Comparisons between laboratory tests and the flaning smoke chamber tests are probably not valid. The degradation mechanisms are expected to differ considerably as is evident from the observed $\mathrm{CO}$ con. centrations ( $2300 \mathrm{ppm}$ ).

\section{GC/MS Analysis of Volatiles from Polymers}

This section summarizes the analysis of the headspace volatiles from the seven selected polymer systems. In the case of two-component systems, each component was analyzed separately. Analysis was done using a computer automated gas cilromatography/ Inass spectrometer (GC/MS) system. Initially, we attempted to identify the volatiles using only gas chromatography. This was not successful mainly because the elution times were not sufficiently reproducible to be matched against listed or suspected compounds.

We then used the computeratomated GC/MS system to identify most of the volatiles. The experimental conditions were as follows:

Columns: 1. $3 \mathrm{~m} \times 3 \mathrm{~mm}$ o.d. glass, packed with Porupak Q. 80 to 100 mesh.

2. $2.8 \mathrm{~m} \times 3 \mathrm{~mm}$ o.d. glass, packed with $10 \%$ OV-3 on 80 to 100 mesh Chiomosorb WAD.

Carrier gas: Helium: flowrate 8 to $12 \mathrm{~cm}^{3} / \mathrm{min}$.

Temperature progran: 65 to $220^{\circ} \mathrm{C}$ at 10 or $15^{\circ} \mathrm{C}$ / min.

Split ratio: $70 \%$ to $\mathrm{MS}$ and $30 \%$ to the flame ionjzation detector (FID).

Injector temperature: $200^{\circ} \mathrm{C}$.

Separator temperature: $150^{\circ} \mathrm{C}$.

Mass range: 12 to 250 automatic mass units (amu).

Integration time: 15 or $20 \mathrm{mis} / \mathrm{amu}$.

Samples of selected liquid polymers and curing agents were stored in glass bottles and sealed with septum caps. The volatiles from the polymers were allowed to equilibrate with the normal air in the containers for at least several hours. The headspacc was sampled through the septum cap with a $5 \mathrm{~cm}^{3}$ gas-tight syringe. The syringe and needle were heated to about $80^{\circ} \mathrm{C}$ and flushed thee times with the headspace gas before withdrawing a sample. This procedure was adopted to minimize loss of material throught adsorption on the internal 
Table 6. Predicted naximum CO concentrations in the smoke chamber under nun-flaming conditions.

$\begin{array}{lcc}\text { Polymer } & \begin{array}{c}300^{\circ} \mathrm{C} \\ \text { Reaction temperature }\end{array} & \begin{array}{c}250^{\circ} \mathrm{C} \\ \text { CCO ppm }\end{array} \\ \text { Saran } & \frac{11^{\circ}}{7} & 3 \\ \text { HydrEpoxy-300 } & 7 & 5 \\ \text { Essex Polyester } & 32 & 12 \\ \text { Resitron } & 9 & 4 \\ \text { EpiCure } & 12 & 4 \\ \text { Aerospray } 70 & 11 & 4 \\ \text { WSU-118 } & 19 & 4\end{array}$

"This value is predicted from the 2-h experiment. From the 0.5 -h experiment we would predict $37 \mathrm{ppm}$; i.e.. a value reasonably in igrement with the measured value.

syringe surfices. The gas sample was then injected into the gas thromitograph. As each component was detec. ted by the FID. the mass spectrum was obtained under compuler control by automatically initiating the mass all near the top of the GC peak. Background spectra were manuilly taken between GC peaks. All samples werc first analyzed on the Porapak $Q$ columm, which is suitable for the separition of relatively low molectular weight compounds (up to C.6 lydirucurbuns). Subrequently we also used the OV-3 columil to sepurate and detett compounds with mulecular wejghts up to about 200 amu.

After we had tentatively identified some of the vapors by their chatacteristic niass spectrum we prepared calibration mixtures contuining $1000 \mathrm{ppm}$ (by volume) of these compounds in trethanol. A $0.5-\mu$ sample of this mixture was then injected to calibrate the FID response and to confirm the mass spectrometric identification. From the recorded GC peak area we salculated calibration tactors that took into account the shange in GC peak shape with increasing elution time. The calibration factors for both columins were uyeraged to estimate the concentrations of all identified compounds in the $5 \mathrm{~cm}^{3}$ headspace samples. The results are rimarized in Table A-10. A typical mass spectrum, which was obtained during analysis of the headspace sumple from Saran XD-7151 Latex. is slown in Fig. 9. This cumpound was readily identified as vinylidene chloi ide.

Although we were informed that WSU-1 18H contained DMP.30 [tris(dimethylaminomethyl)phenol] and DETA (diethylenetriamine), these materials were not identified in the vapors.

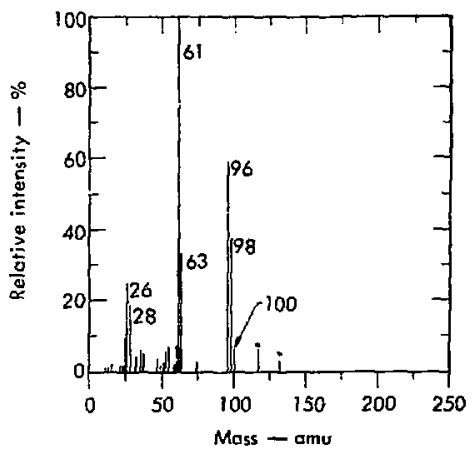

Fig. 9. Mass spectrum of vinylidene chloride from Saran latex (* = background peaks). 
Toxicological Evaliation of Coatings

To evaluate the toxicily of the injterials found by GC/MS in the study of the seven selected coatings, a lable comparing the concentration found to the threshold limit value (TLV) has been compiled (Table A-1 1 in Appendix A). The sample analyzed by GC/MS was collected fre:n above the coating (or its compunents) in a closed container. Exilapolation of concentrations to a real mine situation is difficult. Alowever, if one assumes these values are the noximum concentrations that can result from these costings in a stagnant uir situation, proper ventiation can be used to reduce them to a lower value where necessary. Most of the materials found in the coatings are innocuous with nornal ventilation. However, because of the nature of one or more of the components of their Luring vapors. the Saran XD-7151 latex and the WSU118 coating must be handled carefully. The Saran coating liberates vinylidene chloride (suspect tarcinogen) and the WSU-1 18 liberates vinyl chloride (carcinugen ) and epichlorohydrin (sensitizer).

The snoke and pyrolysis vapors appear to contain litte of toxicologital significance other than $\mathrm{CO}$ and HCe: the latter is present only on pyrolysis of the Saran latex coating. The amount of $\mathrm{CO}$ generated would prububly be small compared to that uvolved from the other lire components, i.e.. burning woot, diesel oil, or other waste materials. Possible "wors1 condition" calculations have been made as follows:

\footnotetext{
"Threshuld linit values refer to airborne concentrations of substances and represent conditions under which it is believed that nearly uil workers may be repeatedly exposed day after day without adverse effect. Because of wide variation in individual susceptibility, however, a small percentage of workers may experience discomfort from some substances at concentrations at or i.iow the threshold Jimit, a smaller percentage may be affocted more seriously by aggravation of pre-existing conditions or by development of an occupational illness.
}

Co concentration in mine shaft:

Calculation conditions:

Mine ventilation rate $=100 \mathrm{ft} / \mathrm{min}$.

Minte dimensions $=8 \mathrm{ft} / 8 \mathrm{ft}$

Film ares liberating $\mathrm{CO}=32 \mathrm{ft}^{2}$.

Volume of air moved through $\mathrm{CO}$ source $=$ $6400 \mathrm{it}^{3} / \mathrm{min}$.

CO liberation rate $=400 \times 550 \mathrm{ppm} / \mathrm{ft}^{2} / \mathrm{tt}^{3}$ itt $30 \mathrm{~min}$ or $7320 \mathrm{ppm} / \mathrm{ft}^{2} / \mathrm{ft}^{3}$ in $1 \mathrm{minh}$.

Calculution: $\left(32 \mathrm{tt}^{2}\right)\left(7320 \mathrm{ppm} / \mathrm{ft}^{2} / \mathrm{ft}^{3}\right)$

$\left(1 / 6400 \mathrm{it}^{3}\right)=36.6 \mathrm{ppin}$ CO average

cullientration/min.

This calculation was made for the Saran coating under flaming conditions and under very poor vemtilation condit tons. The Saran coating gave the highest CO concentration in the smoke chamber. Under these cunditions the calculated $\mathrm{CO}$ concentration is clust is the TLV for CO which is $\mathbf{5 0} \mathrm{ppm}$. Under more normal ventilation conditions, the $\mathrm{CO}$ concentration would be much lower.

HCQ concentration in mine shaft:

Using the data in Tuble $A-4$ and assuming: (1) a 10-mil $(0.254 \mathrm{~mm})$ cating of the Sasan XD. 7151, (2) an $8 \times 8$ fi mine cross sectisn. (3) a minimum air flow of $250 \mathrm{ft} / \mathrm{min}$, and (4) thst the costing reaches $400^{\circ} \mathrm{C}$ with adequate oxygen, we calculate that the pyrolysis of about $1 / 3 \mathrm{ft}^{2}$ per inin of the coating would exceed the 10 ppun level. Even 5 ppin of HCR is highly irrituting sud may be tle maxinum allowable working level. 


\section{References}

1. R.L. Rock and D. K. Walker. Controlling Employec t:xpossure in Alpla Radiation in Undergrumind Urantum Mines (Buteau of Mines. U.S. Dept. uf the lnterim. 1370).

2. P. Meares. J. An. Chem Soc. 76.3415 , 19541.

3. P. Meares, Trans. Faruday Soc. 53.101 (1957).

4. R.A. Pasternak. J.F. Schimsleinker. and J. Itellet. J. Paly'. Sci. S. 467 (1970)

5. D.R. Paul and A.T. DiBenedeltw. J. Poly. Sci., Part C. Niv. 10. 17+H (1965).

6. R.J. Bearman. J. Pliys. Chem.. 61. 70s.71.3 (1957).

7. R.M. Barber and H.T. Clio, J. Poly. Sci.. Part C. Nu, 10. 111-1.38 (1965).

8. J. Crank and G.S. Park, Diffusion in Polyeners (Aeademic Press. London and New Yosk. 1968 ).

9. G.J. Van Amerongen. J. Poly. Sci. 5.307 (1950).

10. G.J. Vin Arterongen. Rubber Chemistry and Tedinulogy 37. 1065 (1964).

11. A.S. Mithaels and H.J. Bixler. J. Poly. Sxi. 50. 393 (1961).

12 A. Aitken and R.M. Barrer. Trans. Faraday Ser. \$1. 116 (1955).

13. R.M. Barrer and G. Skirrow. J. Poly, Sci. 3, S49 (1948).

14. H.J. Bixlet. A.S. Mithazels, and M. Salane, J. Poty. Sci. A. 1, 895 (1905).

15. I. Sibiolev. J.A. Meyer, V. Stannett, and M. Stwatc. J. Poly. Sci. 17. +17 (i955).

16. A.S. Michaels and M.J. Bixler. J. Poly. S.i. 50.293 (1961).

17. A.S. Michacls and H.J. Bixler. J. Poly. Sci. 56. 413 (1961).

12. H. Altu, J, Poly. Sci, \$7, 925 (1962).

19. M. Salanne, Polymet Division Peprints, American Chemical Sicting 8. Nu, 1 (1967).

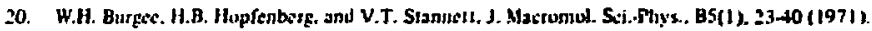

21. J.R. Gaskiti. Just. Fitc alid Flumubility 1, 18:216 (1970).

22. R.H. Boundy and R.F. Boyer. Styrene. Its Polymers. Copolymers, and Derivalives (llaíner Puhlisting Cu.. New York and Londun. 1952) p. 744. 
Appendix A:

Tables and Figures 
Tuble A-1. Permeation coefficients of supponed cuatings."

\begin{tabular}{|c|c|c|c|c|}
\hline \multirow[t]{2}{*}{ Maker, Name } & \multirow[t]{2}{*}{ Type } & \multirow[t]{2}{*}{ Gas } & \multicolumn{2}{|c|}{ Petsueation cocficient of coat ing } \\
\hline & & & $\frac{\operatorname{con}_{\operatorname{sip}}^{3} \cdot \operatorname{con}}{5 \cdot \cos ^{2} \cdot \operatorname{con} l g}$ & $\frac{n m^{2}}{\mathrm{~Pa} \cdot \mathrm{s}}$ \\
\hline Acme, HydrEpoxy 300 & Piznented, water-dispersed Eipaxy & $A_{\mathbf{r}}$ & $6.7 \times 10^{-11}$ & 5.0 \\
\hline Acme, HydrEpoxy 300 Mod I & Pigmented, water-dispersed lipoxy & Ar & $1.4 \times 10^{.11}$ & 1.1 \\
\hline Acme, HydrEpoxy 300 Mod 2 & Pigmented, water-dispersed lipoxy & 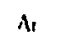 & $7.3 \times 10^{-12}$ & 0.55 \\
\hline Acme, Hydr Cpoxy 300 Mod 2 & Pigmented, water-dispersed lipuxy & $k_{r}$ & $0.8 \times 10^{12}$ & 0.51 \\
\hline Acme, HydrEpoxy $300 \mathrm{Mod} 2$ & Pigmented, water.dispersed Epoxy & $\begin{array}{c}x_{0} \\
\left(R_{n}\right)^{b}\end{array}$ & $\begin{array}{c}5.0 \times 10^{.12} \\
\left(4 \times 10^{-12}\right)\end{array}$ & $\begin{array}{r}0.38 \\
(0.3)\end{array}$ \\
\hline Acme, Hydr Epoxy $156 / 300^{c}$ & Pigmented, waler-dispersed Epoxy & Ar & $1.7 \times 10^{-11}$ & 1.3 \\
\hline Acme, HydrEpoxy 156/300 & Pigmented, witer-dispersed lipoxy & $\mathbf{K}_{\mathbf{r}}$ & $1.4 \times 10^{-11}$ & 1.1 \\
\hline Acme, HydrEpoxy $156 / 300$ & Pigmented, water-dispersed Epoxy & $\begin{array}{c}X_{e} \\
\left(R_{n}\right)\end{array}$ & $\begin{array}{c}1.4 \times 10^{-11} \\
\left(1.3 \times 10^{-11}\right)\end{array}$ & $\begin{array}{l}1.1 \\
(1)\end{array}$ \\
\hline Am. Cyanamid, Aerospray 52 & Alkyd resin dispersiun & Ar & $1.1 \times 10^{-11}$ & 0.83 \\
\hline Am. Cyanamid, Aerospray 70 & Plasticized polyvinyl atetate emulsiun & Ar & $2.4 \times 10^{.11}$ & 1.8 \\
\hline Am. Cyanamid, Aerospray 70 & Plasticized poilyvinyl acetste enulsion & $\mathbf{K r}_{\mathbf{r}}$ & $1.1 \times 10^{-11}$ & 0.83 \\
\hline Am. Cyanamid, Aerospray 70 & Plasticized polyvinyl acetate emulsion & $\begin{array}{c}x_{c} \\
\left(R_{n}\right)\end{array}$ & $\begin{array}{c}1.9 \times 10^{.12} \\
\left(4 \times 10^{.13}\right)\end{array}$ & $\begin{array}{c}0.14 \\
(0.03)\end{array}$ \\
\hline Celanese, EpiRez WD.\$10/EpiCure 879/EpiCure 872 & Non-pigmented, water-dispersed epoxy & Ar & $8.7 \times 10^{.12}$ & 0.65 \\
\hline Celanese, EpiR $c 2$ WE-3520/EpiCure BCT-60-8533 & Non-pigments:, waler-dispersed epoxy & $\mathrm{Ne}$ & $4.5 \times 10^{-11}$ & 3.4 \\
\hline Celanese, EpiRez WE-3520/EpiCure BCT-60-8533 & Non-pignented, water-dispersed epoxy & $\mathrm{Ar}$ & $1.1 \times 10^{-11}$ & 0.83 \\
\hline Celanese, EpiRez WE.3520/EpiCurc BCT-60-8533 & Non-pigmented, waterdispersed epoxy & $\mathbf{K}_{\mathbf{r}}$ & $7.7 \times 10^{-12}$ & $0.5 \mathrm{~s}$ \\
\hline Celanese, EpiRcz WE-3520/EpiCure BCT-60-8533 & Non-pigmented, water-dispersed epuxy & $\begin{array}{c}x_{e} \\
\left(\mathbf{R}_{11}\right)\end{array}$ & $\begin{array}{l}3.5 \times 10^{-12} \\
1.1 \times 10^{-12}\end{array}$ & $\begin{array}{l}0.26 \\
0.083\end{array}$ \\
\hline Dow, Saran XD-4624 & Vinylidene chloride copulymer latex & Ar & $4.4 \times 10^{-13}$ & 0.033 \\
\hline Dow, Saran XD-4624 & Vinylidene chloride copolymer latex & $\mathbf{K}_{r}$ & $2.2 \times 10^{-13}$ & 0.017 \\
\hline Dow, Saran XD-4624 & Vinylidene chluride cupolymer latex & $\begin{array}{c}x_{c} \\
\left(R_{n}\right)\end{array}$ & $\begin{array}{l}8.9 \times 10^{-14} \\
1.8 \times 10^{-14}\end{array}$ & $\begin{array}{l}0.0067 \\
0.0014\end{array}$ \\
\hline
\end{tabular}


Table A-2. Smuke chamber evaitation of coatiugs on asbestus-cement busrd ur sraniun ore.

\section{I ight obscuration data}

\begin{tabular}{|c|c|c|c|c|c|c|c|c|c|c|c|c|c|c|c|c|c|c|c|c|c|c|c|}
\hline \multirow{3}{*}{$\begin{array}{l}\text { Test } \\
\text { No. }\end{array}$} & \multirow[b]{3}{*}{ Substrate } & \multirow[b]{3}{*}{ Costing } & \multirow[b]{3}{*}{ Exposuse } & \multirow{2}{*}{\multicolumn{5}{|c|}{$\begin{array}{c}\text { Speufic uptital deusily" } \\
\text { at time. min }\end{array}$}} & \multirow{3}{*}{30} & \multirow{3}{*}{$\begin{array}{c}\text { Maxunzuin } \\
\text { pecific uplisal } \\
\text { denkity }\end{array}$} & \multirow{3}{*}{ 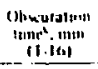 } & \multirow{2}{*}{\multicolumn{2}{|c|}{5}} & \multirow{2}{*}{\multicolumn{8}{|c|}{ 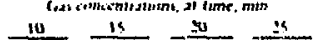 }} & \multirow{2}{*}{\multicolumn{2}{|c|}{10}} \\
\hline & & & & & & & & & & & & & & & & & & & & & & & \\
\hline & & & & 5 & 10 & 15 & 20 & $\geq 5$ & & & & (b) & (T), & (T) & (1), & (1) & ri1: & 0 & st. & to & to, & (t) & ix: \\
\hline GH.I & AC Bd & None & NF & 0 & 0 & 0 & 0 & & & 0 & NK & & & & & & & & & & & & \\
\hline GI1.2 & A-C Bd & Nune & $\mathbf{F}$ & 0 & o & 0 & o & & & 0 & NK & & & & & & 119 & & Un & & & & \\
\hline GH-? & $A-C B d$ & HydrE.poxy 300 & NF & 2 & 7 & 1.3 & 20 & 24 & 36 & 3 & 17.4 & & & & & & & & & & & & \\
\hline CH-4 & $A-C B d$ & Hydrt:poxy 300 & $\mathrm{r}$ & 2 & 11) & 20 & 34 & 35 & 36 & $36=$ & 164 & & & 125 & 1) & $2(x)$ & 01 & 280 & 10 & $4 x$ & $1:$ & & \\
\hline CH-5 & UOH & Nouse & $F$ & 0 & 0 & 2 & 2 & $\div$ & $\div$ & $\therefore$ & $\mathrm{NH}$ & & & & & & & ;0 & 1.0 & & & & \\
\hline GHO & vois & vathe & Nr & 0 & 1 & 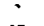 & 2 & 2 & 2 & $\therefore$ & $\mathbf{S H}$ & & & & & & & & & & & & \\
\hline GH.7 & Uore & Hydst:puxy 3(N) & $F$ & $\therefore$ & In, & .37 & so & 50 & it & $s 1$ & 114 & StI & ") & 1511 & at & ans & $"$ & $24 !$ & U日 & Iron & $\because:$ & 541 & 11 \\
\hline GI1.X & llorc & HydrEpuxy 300 & NF & ) & + & 11 & 17 & $\because 2$ & 30 & .31 & in." & & & & & & & & & & & & \\
\hline GH.9 & AC Bd & $x(1) .7151$ & $F$ & 0 & 1 & 1 & 1 & 1 & 1 & 1 & $x$ & & & 1511 & $11+$ & 175 & $\mathbf{3} \cdot$ & :41 & $U n$ & $: \pi$ & 11 & 80 & 1: \\
\hline GH-1L & ACBd & $\times 10.7151$ & $\mathrm{NF}$ & (1 & () & 1 & I & । & 1 & I & NH & & & & & $\$$ & & An & 11 & Mo & to: & 90 & 111 \\
\hline GH.12 & AC Bd & $x \mid) .7|5|$ & $\mathbf{F}$ & I & 1 & $!$ & 2 & $:$ & 2 & 2 & YH & 75 & 114 & $\therefore(n)$ & us & Snd & J. & tint & 111 & +121 & 1: & tut & $1+$ \\
\hline CH.13 & I Ore & X1).7151 & $F$ & 0 & 11 & 1 & 1 & 11 & 1 & 1 & $v \mathbf{k}$ & IIX] & $\mathbf{0}$ & $3 \mathbf{s t}$ & 0.1 & ixn & 04 & 500 & o.6 & 4 & 111 & $\sin$ & 1: \\
\hline GH.14 & Norc & $x \mid 2.7151$ & NF- & 0 & 11 & 1 & 2 & 2 & $I$ & $\therefore$ & NH & & & & & 818 & 0 & $m$ & a & no & $\omega$ & In] & " \\
\hline GH.15 & $A \cdot C B d$ & lissex l'alywster & N!- & 0 & $s$ & 14 & $\because$ & $3 x$ & $=1$ & $\therefore$ & $15 x$ & & & & & & & & & & & : 11 & \\
\hline GH.I6 & A.C Bd & Esax Pilyesier & $F$ & 11 & 34 & .34 & 30 & 30 & 26 & $"$ & 101 & 20 & 0.: & 30 & ds & 40 & $0 \pi$ & sit & 11 & MI & 12 & in & $1 \%$ \\
\hline GH.17 & A.C BA & Resitron II & NF & 0 & 0 & $\mathbf{u}$ & 0 & 1 & 1 & 1 & $v k$ & & & & & & & & & & & $x$ & \\
\hline GH-18 & A.C Bd & Resitron II & $\mathbf{F}$ & 0 & 2 & 4 & $b$ & 7 & 7 & 7 & $\mathbf{s k}$ & 20 & 0.2 & $\$ 0$ & 0,1 & so & 0.5 & m. & U." & Nis & 11 & $\operatorname{mon}$ & I \\
\hline GH-14) & $A \subset B d$ & Resitron II & $F$ & 2 & 4 & 7 & 8 & y & " & 10 & $N K$ & 20 & 0.2 & In & 05 & 50 & 0.5 & 6 & $1:$ & $\mathbf{x} \mathbf{1}$ & $1+$ & $+4 / 3$ & 16 \\
\hline GH.20 & $A-C B d$ & WSU-118 & NF & 10 & 25 & 54 & 77 & 92 & 10: & 102 & $1:$ & & & & & & & & & & & & \\
\hline Gti-21 & $A \subset$ Bd & WSU-1 18 & $\mathbf{F}$ & so & xu) & (1) & 111 & & & 111 & 24 & & & & & & & HNI & & & & & \\
\hline GH-2I & A.C Bd & Acrospray 70 & NF & 41 & $\mathrm{H}_{3}$ & ओ & $\mathrm{k7}$ & & & 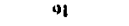 & $\therefore 4$ & & & & & & & & & & & & \\
\hline GH-23 & A.C Bd & Aerospray 70 & $\mathbf{F}$ & 55 & 87 & $\times 7$ & & & & $k i$ & 23 & low & & 100 & & $; 01$ & & & & & & & \\
\hline GH.24 & $A \cdot C B d$ & WD.510/872 & $\mathbf{N F}$ & 1.5 & $\mathbf{J 3}$ & $x^{3}$ & 12.6 & 155 & 17: & 172 & 44 & & & & & & & & & & & & \\
\hline Gl1.25 & Ac Bd & WD-510/872 & $\mathbf{F}$ & 8.3 & 17 & 195 & & & & 177 & 05 & sing & & $: 40$ & & 119u & & & & & & & \\
\hline GH.26 & AC Bd & WD.510/872/879 & NF & 17 & 27 & $d 4$ & 57 & ind & 76 & 76 & +7 & & & & & & & & & & & & \\
\hline GH.27 & A.C Bd & WD.S10/872/874 & $F$ & 59 & 119 & 147 & 147 & & & 150 & i2 & 1511 & & 250 & & & & tul & & & & & \\
\hline GH.28 & AC Bd & Promulion 200 & $\mathrm{NF}$ & 5 & 20 & 50 & 71 & 84 & $x^{*}$ & Nil & 7.7 & & & & & & . & & & & & & \\
\hline GH.29 & Ac Bd & Pramulsion 200 & I: & 58 & 105 & 122 & & & & $1::$ & 21 & & & & & $\because 1$ & & & & & & & \\
\hline $\mathrm{GH} \cdot 30$ & AC Bd & Hydruseal & NI- & 2 & 4 & 10 & ik & $2 b$ & .15 & 42 & $1 \times .0$ & & & & & & & & & & & & \\
\hline GH.3! & $A \cdot C$ Bd & Hydoo Scal & 1: & 7 & 34 & 52 & $5 k$ & & & $5 k$ & 10.K & & & & & & & & & & & & \\
\hline 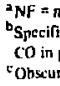 & $\begin{array}{l}\text { non Daming } \\
\text { fie optiteal d } \\
\text { Ppin: } \mathrm{CO}_{2} \\
\text { Jation time }\end{array}$ & 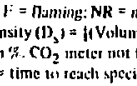 & 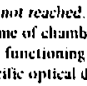 & Are: & $\begin{array}{l}\text { 11) } \operatorname{cm} \\
\text { 11) Lov } \\
\text { If (sev }\end{array}$ & Lung s & $\begin{array}{l}\text { Silliace } \\
\text { Jeicuta }\end{array}$ & $=x$ le & $\begin{array}{l}\text { nils } \\
\text { nils }\end{array}$ & 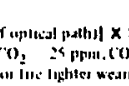 & 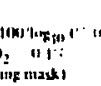 & & & & & & & & & & & & \\
\hline
\end{tabular}


Table A-3. Pyrolysis study of HyurEpoxy 300.

\begin{tabular}{|c|c|c|c|c|c|c|c|c|c|c|c|c|c|c|c|}
\hline \multirow{2}{*}{$\begin{array}{l}\text { Sample } \\
\text { wt, nig }\end{array}$} & \multirow{2}{*}{$\begin{array}{l}\text { Residue } \\
\text { wt, mg }\end{array}$} & \multirow{2}{*}{$\begin{array}{c}\text { Wt loss, } \\
\mathrm{mg}\end{array}$} & \multirow{2}{*}{$\begin{array}{r}\text { Loss } \\
\text { wt, \% }\end{array}$} & \multirow{2}{*}{$\begin{array}{c}\text { Surface } \\
\text { area, m(n }\end{array}$} & \multirow{2}{*}{$\begin{array}{c}\text { Pyro } \\
\text { temp. }{ }^{\circ} \mathrm{C}\end{array}$} & \multirow{2}{*}{$\begin{array}{c}\text { Pyro } \\
\text { time, }\end{array}$} & \multicolumn{4}{|c|}{ Giss cvolved. Lin' } & \multicolumn{4}{|c|}{ 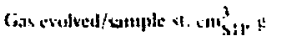 } & \multirow{2}{*}{ "1, le.s. } \\
\hline & & & & & & & co & $\mathrm{CO}_{2}$ & $\mathrm{CII}_{4}$ & $\mathrm{C}_{2} \mathrm{H}_{6}$ & Co & $\mathrm{CO}_{2}$ & $\mathrm{CII}_{4}$ & $r_{2}$ & \\
\hline 25.244 & 23.909 & 1.335 & 5.3 & 166 & 200 & 16.0 & 0.18 & 0.38 & $\sim 0$ & $\sim_{0}$ & 7 & 15 & $\sim 0$ & $\sim_{0}$ & $4 .:$ \\
\hline 25.476 & 23.742 & 1.734 & 6.8 & 133 & 200 & 29.5 & 0.50 & 0.53 & $\sim 0$ & $\sim 0$ & 20 & 21 & $\sim 0$ & 20 & $7 . \pi$ \\
\hline 25.348 & 22.337 & 3.011 & 11.9 & 139 & 300 & 2.0 & 0.42 & 1.08 & $\sim 0$ & $\sim_{0}$ & 17 & $4: 3$ & $\sim_{0}$ & 20 & 10.4 \\
\hline 24.633 & 20.150 & 4.483 & 18.2 & 133 & 300 & 16.0 & 1.13 & 2.28 & 0.02 & 20 & 44 & 90 & 4 & $v(1$ & 37.2 \\
\hline 25.400 & 16.360 & 9.040 & 35.6 & 132 & 400 & 2.0 & 2.29 & 6.24 & 0.02 & $\sim 0$ & $\%$ & 246 & 4 & $\sim_{0}$ & $\$ 1.1$ \\
\hline 25.354 & 18.234 & 7.120 & 28. & 95 & 400 & 0.5 & 0.96 & 1.86 & 0.04 & 0.01 & 58 & $7:$ & 2 & 1 & 18.4 \\
\hline 25.074 & 12.880 & 12.194 & 48.6 & 99 & 600 & 0.5 & $\sim 0$ & 11.6 & $\sim 0$ & $\sim 0$ & $\sim_{0}$ & 402 & $\sim 0$ & $\sim_{0}$ & $53 \mathrm{n}$ \\
\hline 25.110 & 11.965 & 13.145 & 52.4 & 96 & 800 & 0.5 & $\sim_{0}$ & 12.7 & $\sim_{0}$ & $\sim 0$ & $\sim_{0}$ & 506 & $\sim_{0}$ & $\sim 0$ & 57.9 \\
\hline
\end{tabular}


Table A-4. Pyrolysis study of Saran XD-7151 film

(95\% Saran plus $5 \%$ polyvinyl alcohol solution).

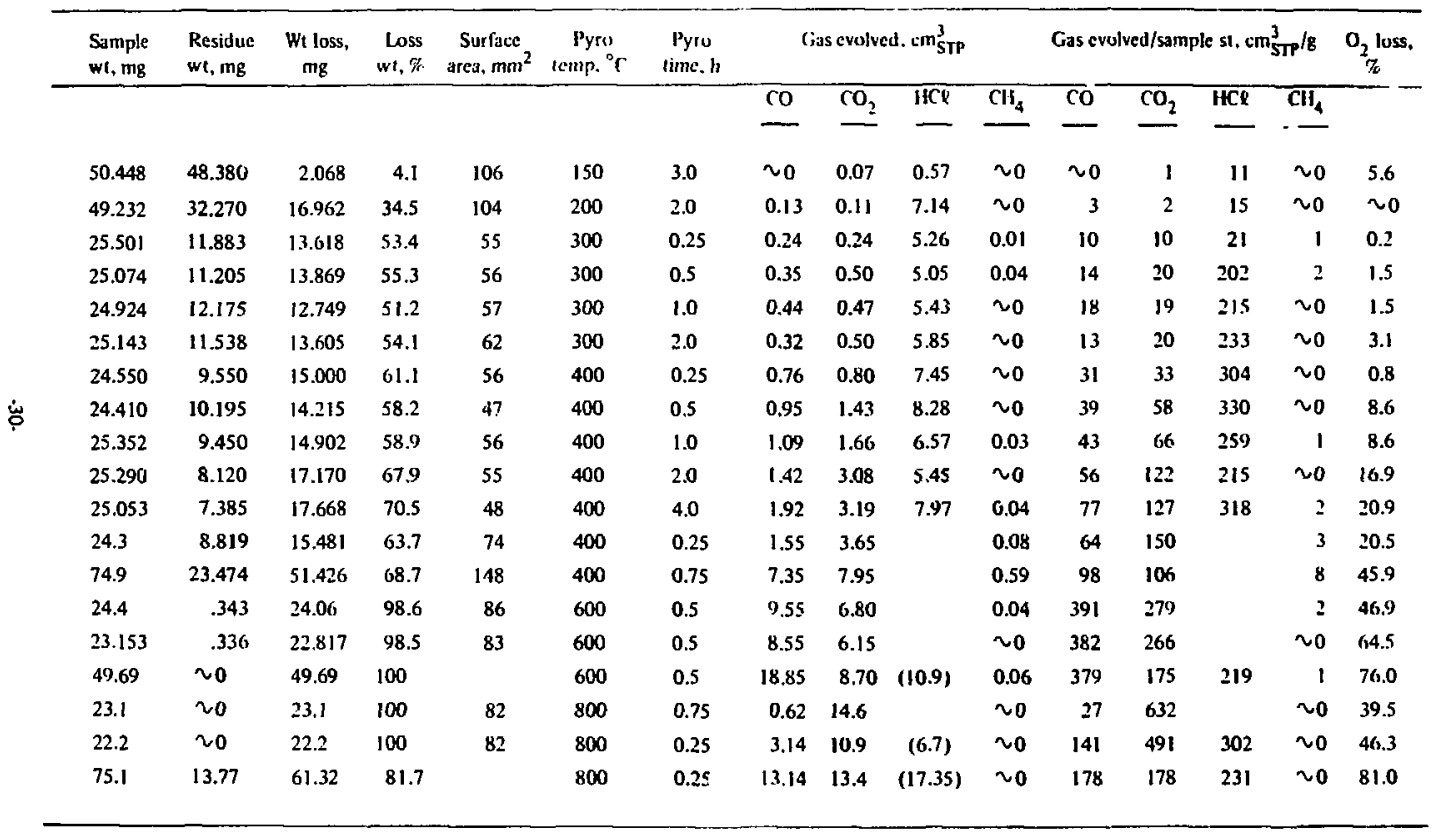


Table A-5. Pyrolysis study of Essex Polycster.

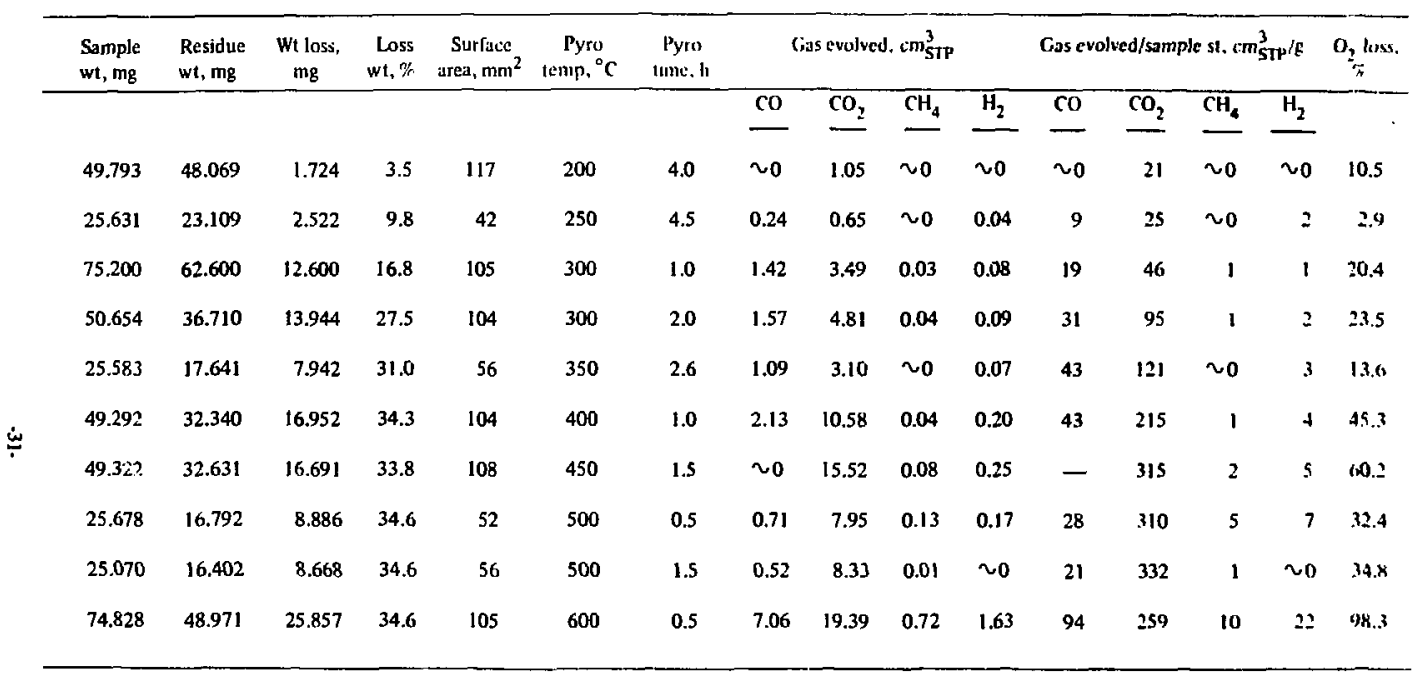


Table A-6. Pyrolysis study of Ventron's Resitron II.

\begin{tabular}{|c|c|c|c|c|c|c|c|c|c|c|c|c|c|c|c|}
\hline \multirow{2}{*}{$\begin{array}{l}\text { Sample } \\
\text { wt, mg }\end{array}$} & \multirow{2}{*}{$\begin{array}{l}\text { Residue } \\
\text { wt, mg }\end{array}$} & \multirow{2}{*}{$\begin{array}{c}\text { Wt loss, } \\
\text { mg }\end{array}$} & \multirow{2}{*}{$\begin{array}{r}\text { Loss } \\
\text { wt, \% }\end{array}$} & \multirow{2}{*}{$\begin{array}{c}\text { Surface } \\
\text { area, } \mathrm{mm}^{2}\end{array}$} & \multirow{2}{*}{$\begin{array}{c}\text { Pyro } \\
\text { temp, }{ }^{\circ} \mathrm{C} \\
\end{array}$} & \multirow{2}{*}{$\begin{array}{c}\text { Pyro } \\
\text { time, h }\end{array}$} & \multicolumn{4}{|c|}{ Gas evolved, $\mathrm{cm}_{\mathrm{STP}}^{3}$} & \multicolumn{4}{|c|}{ Gas evolved/sample st, $\mathrm{cm}_{\mathrm{sTP}}^{3} / \mathbf{g}$} & \multirow{2}{*}{$\underset{\%}{\mathrm{O}_{2} \text { loss, }}$} \\
\hline & & & & & & & $\mathrm{CO}$ & $\mathrm{CO}_{2}$ & $\mathrm{CH}_{4}$ & $\mathrm{C}_{2} \mathrm{H}_{6}$ & $\mathrm{CO}$ & $\mathrm{CO}_{2}$ & $\mathrm{CH}_{4}$ & $\mathrm{C}_{2} \mathrm{H}_{6}$ & \\
\hline 40.500 & 45.364 & 4.136 & 8.4 & 127 & 150 & 4.0 & $\sim_{0}$ & 0.20 & $\sim 0$ & $\sim_{0}$ & $\sim 0$ & 4 & $\sim 0$ & $\sim 0$ & 1.4 \\
\hline 75.222 & 72.712 & 2.510 & 3.3 & 165 & 150 & 6.0 & 0.32 & 0.30 & $\sim 0$ & $\sim 0$ & 4 & 4 & $\backsim 0$ & $\sim 0$ & 2.5 \\
\hline 50.416 & 45.892 & 4.524 & 9.0 & 138 & 200 & 2.0 & 0.18 & 0.43 & $\sim_{0}$ & $\sim_{0}$ & 4 & 9 & $\sim_{0}$ & $\sim_{0}$ & 4.6 \\
\hline $74.557^{\circ}$ & 67.284 & 7.273 & 9.8 & 150 & 250 & 1.0 & 0.42 & 1.74 & $\sim_{0}$ & $\sim_{0}$ & 6 & 23 & $\sim 0$ & $v_{0}$ & 5.4 \\
\hline 30.359 & 44.900 & 5.459 & 10.8 & 127 & 300 & 1.0 & 0.27 & $: .38$ & 0.01 & $\sim_{0}$ & 5 & 27 & $\sim_{0}$ & $\sim 0$ & 4.3 \\
\hline 25.506 & 21.300 & 4.206 & 16.5 & 56 & 350 & 1.0 & 0.38 & 0.83 & 0.05 & $\sim 0$ & 15 & 32 & 2 & $v_{0}$ & 2.6 \\
\hline 25.314 & 18.312 & 7.002 & 27.7 & 25 & 400 & 0.5 & 0.45 & 1.23 & 0.07 & $\sim 0$ & 18 & 49 & 3 & $v_{0}$ & 6.4 \\
\hline 75.178 & 57.403 & 17.775 & 23.6 & 138 & 450 & 0.25 & 1.56 & 3.87 & 0.44 & 0.08 & 21 & 51 & 6 & 1 & 14.2 \\
\hline 25.165 & 12.650 & 12.515 & 49.7 & 27 & 600 & 0.5 & 0.85 & 14.61 & $\sim 0$ & $\sim 0$ & 34 & 581 & $\sim 0$ & $\nu_{0}$ & 74.2 \\
\hline
\end{tabular}


Table A-7. Pyrolysis study of Aeruspray 70.

\begin{tabular}{|c|c|c|c|c|c|c|c|c|c|c|c|c|c|c|c|}
\hline \multirow{2}{*}{$\begin{array}{l}\text { Sample } \\
\text { wI. mg }\end{array}$} & \multirow{2}{*}{$\begin{array}{l}\text { Residue } \\
\text { wt. mg }\end{array}$} & \multirow{2}{*}{$\begin{array}{l}\text { We loss. } \\
\text { lng }\end{array}$} & \multirow{2}{*}{$\begin{array}{l}\text { Luss } \\
w 1 . \%\end{array}$} & \multirow{2}{*}{$\begin{array}{l}\text { Surface } \\
\text { ared, mom² }\end{array}$} & \multirow{2}{*}{$\begin{array}{l}\text { Pyrs, } \\
\text { temp. }{ }^{\circ} \mathrm{C}\end{array}$} & \multirow{2}{*}{$\begin{array}{l}\text { Pyro } \\
\text { time. hl }\end{array}$} & \multicolumn{4}{|c|}{ Gus crolved. cin str } & \multicolumn{4}{|c|}{ Gas evolved/simple st. cm STP ${ }_{\text {ST }}^{3}$} & \multirow{2}{*}{$\mathrm{O}_{2}$ loss. } \\
\hline & & & & & & & $\mathrm{co}$ & $\mathrm{CO}_{2}$ & $\mathrm{CH}_{4}$ & $\mathrm{H}_{2}$ & $\mathrm{CO}$ & $\mathrm{CO}_{2}$ & $\mathrm{CH}_{4}$ & $\mathrm{H}_{2}$ & \\
\hline 75.602 & 63.423 & 12.179 & 16.1 & 195 & 200 & 4.0 & 014 & 0.52 & $\sim_{0}$ & 0.06 & 2 & 7 & $\sim_{0}$ & 1 & 2.7 \\
\hline 75.943 & 62.042 & 13.001 & 17.3 & 163 & 250 & 3.0 & .50 & 1.25 & 0.04 & $\sim_{0}$ & 7 & 17 & 1 & $\sim_{0}$ & 10.8 \\
\hline 51.001 & 14.709 & 36.392 & 71.4 & 144 & 300 & 3.0 & 1.12 & 2.58 & .18 & $\sim 0$ & 22 & 50 & 4 & $\sim 0$ & 20.0 \\
\hline 50.326 & 12.197 & 38.129 & 75.8 & 98 & 350 & 2.0 & 1.97 & 4.09 & 0.10 & 0.07 & 39 & 80 & 2 & 1 & 28.3 \\
\hline 50.550 & 9.554 & 40.996 & 81.1 & 154 & 400 & 3.0 & 4.52 & 13.01 & 0.28 & 0.16 & 90 & 257 & 6 & 3 & 88.5 \\
\hline 74.905 & 6.953 & 67.952 & 90.7 & 175 & 450 & 1.75 & 8.36 & 17.39 & 0.84 & 0.35 & 112 & 230 & 10 & 5 & 99.1 \\
\hline 25.673 & 0.155 & 25.518 & 99.4 & 55 & 500 & 1.0 & 7.01 & 14.30 & 0.74 & 0.36 & 273 & 557 & 29 & 14 & 71.8 \\
\hline 25.452 & 0.086 & 25.366 & 99.7 & 42 & 550 & 1.0 & 6.53 & 13.52 & 0.61 & 0.30 & 256 & 531 & 24 & 12 & 83.9 \\
\hline 25.494 & 0.41 ? & 25.082 & 98.4 & 46 & 600 & 0.5 & 4.80 & 20.96 & 0.09 & 0.10 & 188 & 822 & 4 & 4 & 88.0 \\
\hline
\end{tabular}




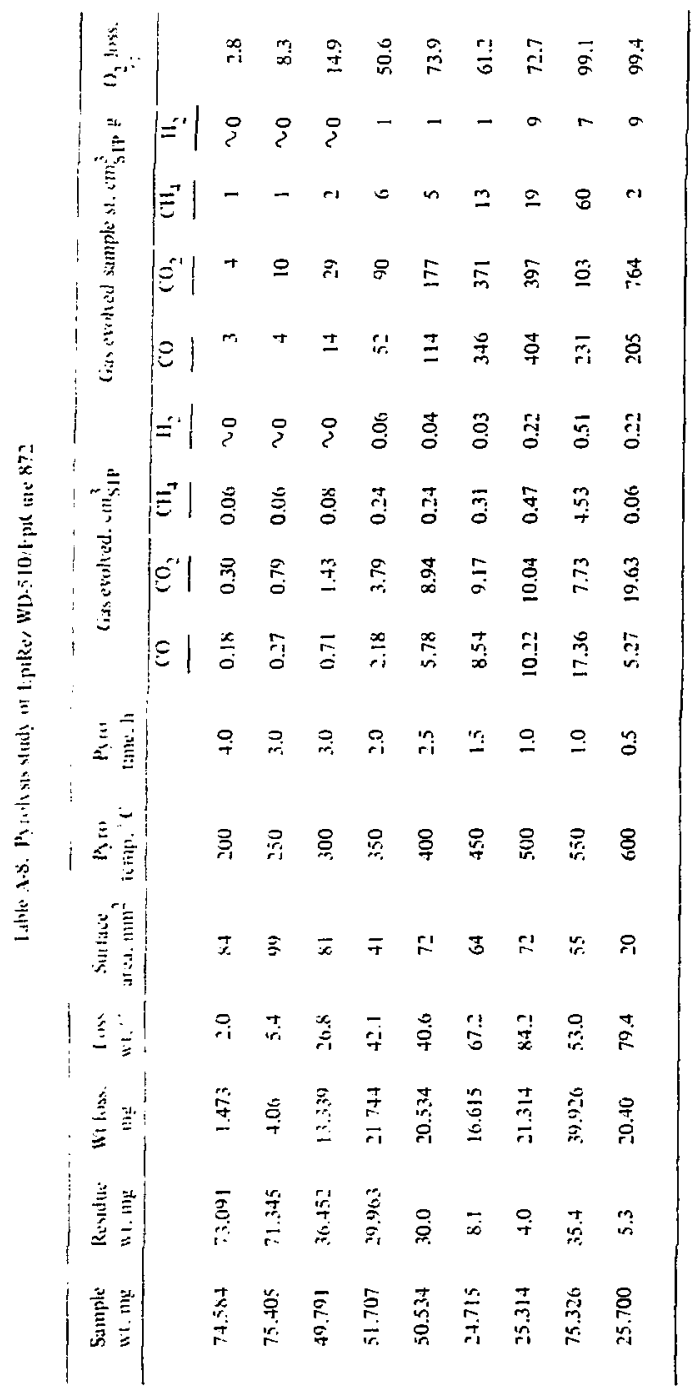




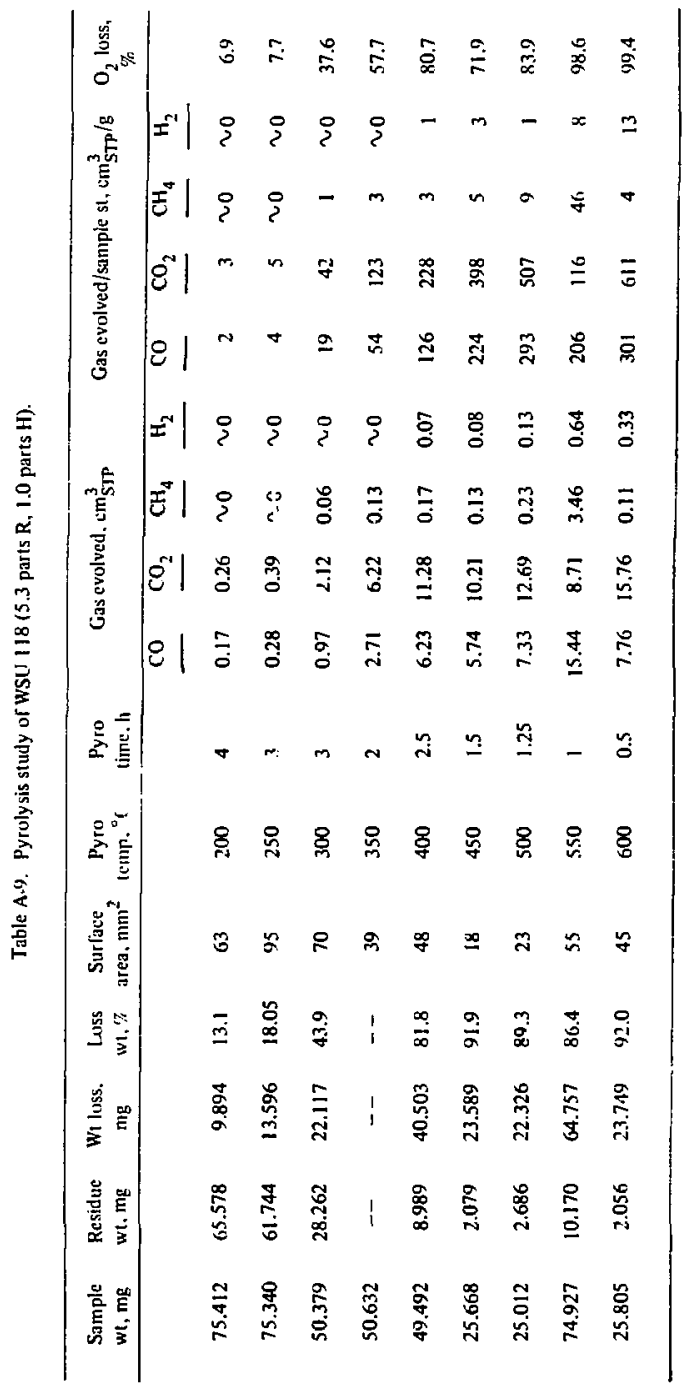


Table A-10. TLV of organic materials released during suring of several radon barrier coatings.

\begin{tabular}{|c|c|c|c|c|}
\hline Coating & Compound & Volumse found, ppm & TLV : :pm & Personal guess. ppm \\
\hline EpiRez WD.510 & $\begin{array}{l}\text { Acetone } \\
\text { MEK } \\
\text { Butanol } \\
\text { Toluene } \\
\text { Xylene } \\
\text { 2-Ethoxy ethylacetate } \\
\text { 2-Methyl butanol }\end{array}$ & $\begin{array}{c}25-49 \\
10.24 \\
10.24 \\
10-24 \\
0.9 \\
10.24 \\
100-199\end{array}$ & $\begin{array}{r}1000 \\
200 \\
100 \\
100 \\
100 \\
100 \\
--\end{array}$ & 10rs \\
\hline EpiCure 872 & $\begin{array}{l}\text { Ethylene } \\
\text { Propane } \\
\text { Vinyl Acetate } \\
\text { Toluent } \\
\text { Xylene } \\
\text { Etloyl benzene }\end{array}$ & $\begin{array}{c}10-24 \\
0-9 \\
10-24 \\
10-24 \\
10-24 \\
200-399\end{array}$ & $\begin{array}{r}1000 \\
1000 \\
10 \\
100 \\
100 \\
100\end{array}$ & \\
\hline $\begin{array}{l}\text { Resitron II } \\
\text { (Resin) }\end{array}$ & $\begin{array}{l}\text { Metlianol } \\
\text { 2-Mlethyl furan } \\
\text { Vinyl acetute } \\
\text { MEk } \\
\text { Acetone } \\
\text { Furfural } \\
\text { Furfuryl alcohol }\end{array}$ & $\begin{array}{c}0-9 \\
0-9 \\
0-9 \\
0-9 \\
25-49 \\
25-49 \\
200.399\end{array}$ & $\begin{array}{r}200 \\
-- \\
10 \\
200 \\
1000 \\
5 \\
5\end{array}$ & 10 \\
\hline Aerospray 70 & $\begin{array}{l}\text { Acetaldehyde } \\
\text { l:thanol } \\
\text { Vinyl dectate } \\
\text { Acetone }\end{array}$ & $\begin{array}{c}0.9 \\
0-9 \\
200-399 \\
400-699\end{array}$ & $\begin{array}{r}100 \\
1000 \\
10 \\
1000\end{array}$ & \\
\hline $\begin{array}{l}\text { Hydrl:poxy } 300 \\
\text { (A component) }\end{array}$ & $\begin{array}{l}\text { Elliylene } \\
\text { Acetone } \\
\text { Vinyl acetate }\end{array}$ & $\begin{array}{l}25-49 \\
10 \cdot 24 \\
25-49\end{array}$ & $\begin{array}{r}1000 \\
1000 \\
10\end{array}$ & \\
\hline $\begin{array}{l}\text { Hydrtipoxy } 300 \\
\text { (B component) }\end{array}$ & $\begin{array}{l}\text { Acetone } \\
\text { Vinyl acetate }\end{array}$ & $\begin{array}{l}0-9 \\
0.9\end{array}$ & $\begin{array}{r}1000 \\
10\end{array}$ & \\
\hline $\begin{array}{l}\text { Saran XD-7151 } \\
\text { Litex }\end{array}$ & $\begin{array}{l}\text { 2-Methyl propene } \\
\text { Butanol } \\
\text { 2-Methyl-2-propanol } \\
\text { Butyl acrylate } \\
\text { Vinylidene clloride } \\
\text { Acelone } \\
\text { Acrylonitrile }\end{array}$ & $\begin{array}{c}0.9 \\
0-9 \\
25-49 \\
50-99 \\
100-199 \\
200-399 \\
20-399\end{array}$ & $\begin{array}{r}-- \\
100 \\
100 \\
-- \\
-- \\
1000 \\
20\end{array}$ & $\begin{array}{c}200 \\
10-100 \\
1-10\end{array}$ \\
\hline
\end{tabular}


Table A-10. TLV of organic materials relessed during curing of several radon barrier coatings (continued).

\begin{tabular}{|c|c|c|c|c|}
\hline Coating & Compuund & Volume found.ppm & TLV, ppm & Personal guess, ppm \\
\hline $\begin{array}{l}\text { Essex Polyester } \\
\left(\text { fresh }^{3}\right)\end{array}$ & $\begin{array}{l}\text { MEK } \\
\text { Styrenc } \\
\text { Toluene } \\
\text { Acetone }\end{array}$ & $\begin{array}{c}25-49 \\
200-399 \\
400 \cdot 699 \\
10,000+\end{array}$ & $\begin{array}{r}200 \\
100 \\
100 \\
1000\end{array}$ & \\
\hline $\begin{array}{l}\text { Essex Polyester } \\
\left(\text { after } 48 \mathrm{~h}^{\mathrm{b}}\right)\end{array}$ & $\begin{array}{l}\text { Ethylene chloride } \\
\text { MEK } \\
\text { Styrene } \\
\text { Acetone }\end{array}$ & $\begin{array}{c}10-24 \\
25-49 \\
700-999 \\
>20,000\end{array}$ & $\begin{array}{r}50 \\
200 \\
100 \\
1000\end{array}$ & \\
\hline $\begin{array}{l}\text { Essex Polyester } \\
\text { (after curing } \\
\text { total gas) }\end{array}$ & $\begin{array}{l}\text { Toluene } \\
\text { Propyl heptanol } \\
\text { Ethyl benzene } \\
\text { Xylene } \\
\text { Benzene } \\
\text { Isopropyl benzene } \\
\text { Acetone }\end{array}$ & $\begin{array}{c}10-24 \\
200-399 \\
400-699 \\
700-999 \\
1000-2499 \\
1000-2499 \\
2500-10,000\end{array}$ & $\begin{array}{r}100 \\
- \\
100 \\
100 \\
25 \\
50 \\
1000\end{array}$ & $10-100$ \\
\hline $\begin{array}{l}\text { Essex Polyester } \\
\text { (vapor over cured } \\
\text { material) }\end{array}$ & $\begin{array}{l}\text { Benzene } \\
\text { Benzaldelhyde } \\
\text { Acetone }\end{array}$ & $\begin{array}{c}10-24 \\
50-99 \\
200-399\end{array}$ & $\underset{1000}{25}$ & $10-100$ \\
\hline $\begin{array}{l}\text { WSU.1 } 18 \\
\text { (R component }{ }^{\mathrm{a}} \text { ) }\end{array}$ & $\begin{array}{l}\text { Vinyl chloride } \\
\text { Ethylene chloride } \\
\text { Epichlorohydrin } \\
\text { Acetone }\end{array}$ & $\begin{array}{c}25-49 \\
50.99 \\
50.99 \\
104.199\end{array}$ & $\begin{array}{r}1 \\
50 \\
5 \\
1000\end{array}$ & \\
\hline $\begin{array}{l}\text { WSU-1 } 18 \\
\left.\text { (H component }{ }^{2}\right)\end{array}$ & $\begin{array}{l}\text { Trinethylamine } \\
\text { Toluene } \\
\text { Dimethylamine } \\
\mathbf{A}^{\mathbf{C}} \\
\mathbf{B}^{\mathbf{C}}\end{array}$ & $\begin{array}{c}20 \mathrm{~J}-399 \\
400-699 \\
1000-2499\end{array}$ & $\begin{array}{r}-- \\
100 \\
10 \\
-- \\
--\end{array}$ & $\begin{array}{l}10 \\
? \\
?\end{array}$ \\
\hline \multicolumn{5}{|c|}{$\begin{array}{l}\text { Poropak Q column only: To check styrene conte } t \text { in fresh material. } \\
\text { b Stabilized styrene: different elution time. } \\
\text { c Unresolved compound: excludes, DMP-30, DETA. }\end{array}$} \\
\hline
\end{tabular}




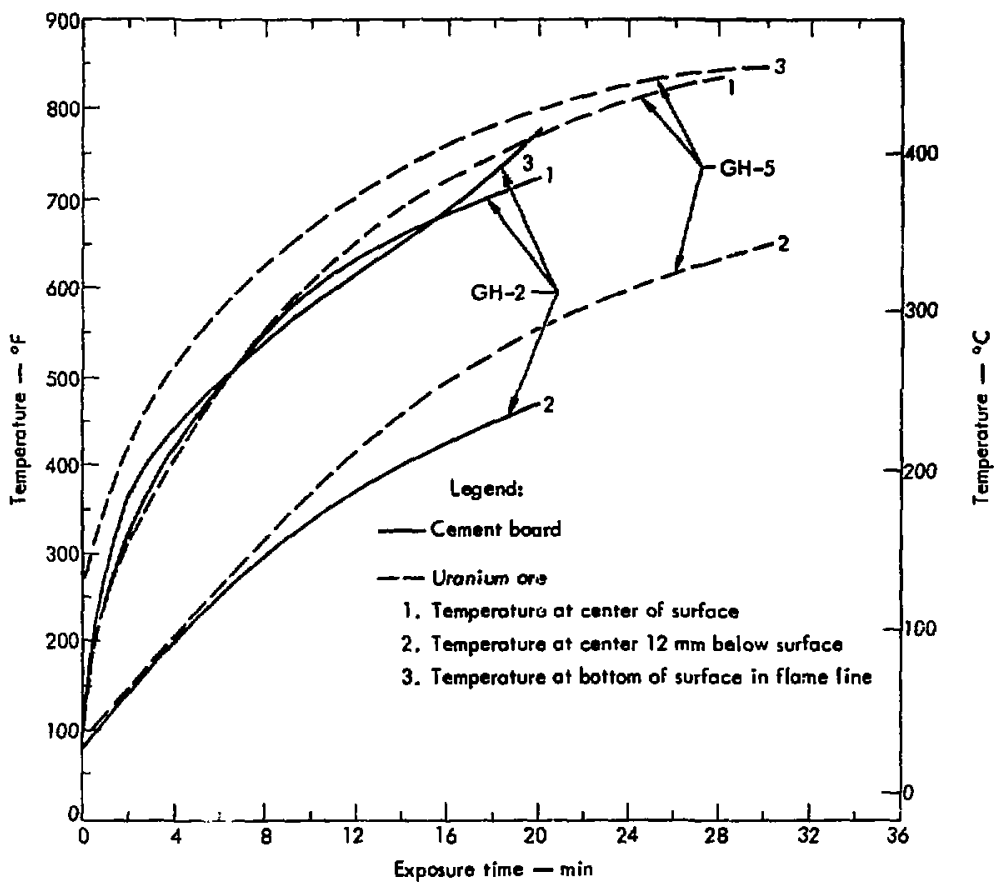

Fig. A.l. Surface and body temperatues of uncoated cement-board and uranium-ore squares exposed to $2.5 \mathrm{~W} /$ $\mathrm{cm}^{2}$ radiant heat with pijot flame. 


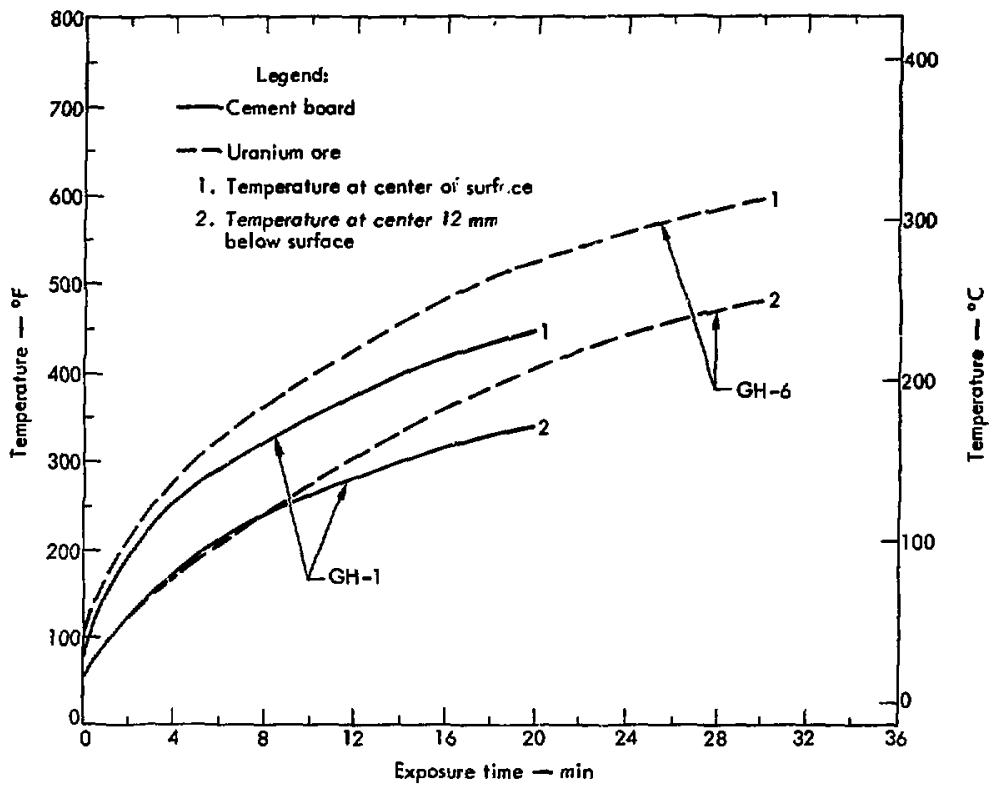

Fig. A-2. Surface and body temperatures of uncoated cement-board and uranium-ore squares exposed to $2.5 \mathrm{~W} / \mathrm{cm}^{2}$ radiant heat, without pilot flame. 


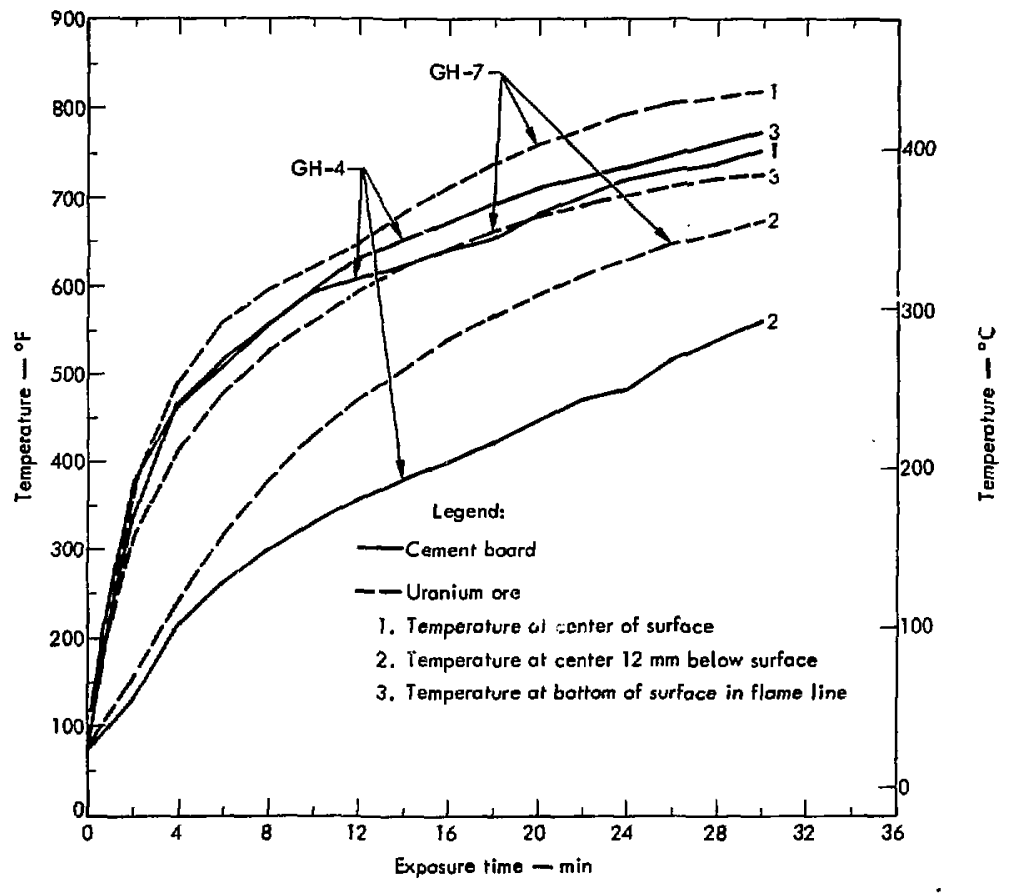

Fig. A-3. Surface and body temperature of cement-board and uranium-ore squares whose front surface had been coated with 10 mils of HydrEpoxy 300 . The squares were exposed to $2.5 \mathrm{~W} / \mathrm{cm}^{2}$ radiant heat with pilot flane. 


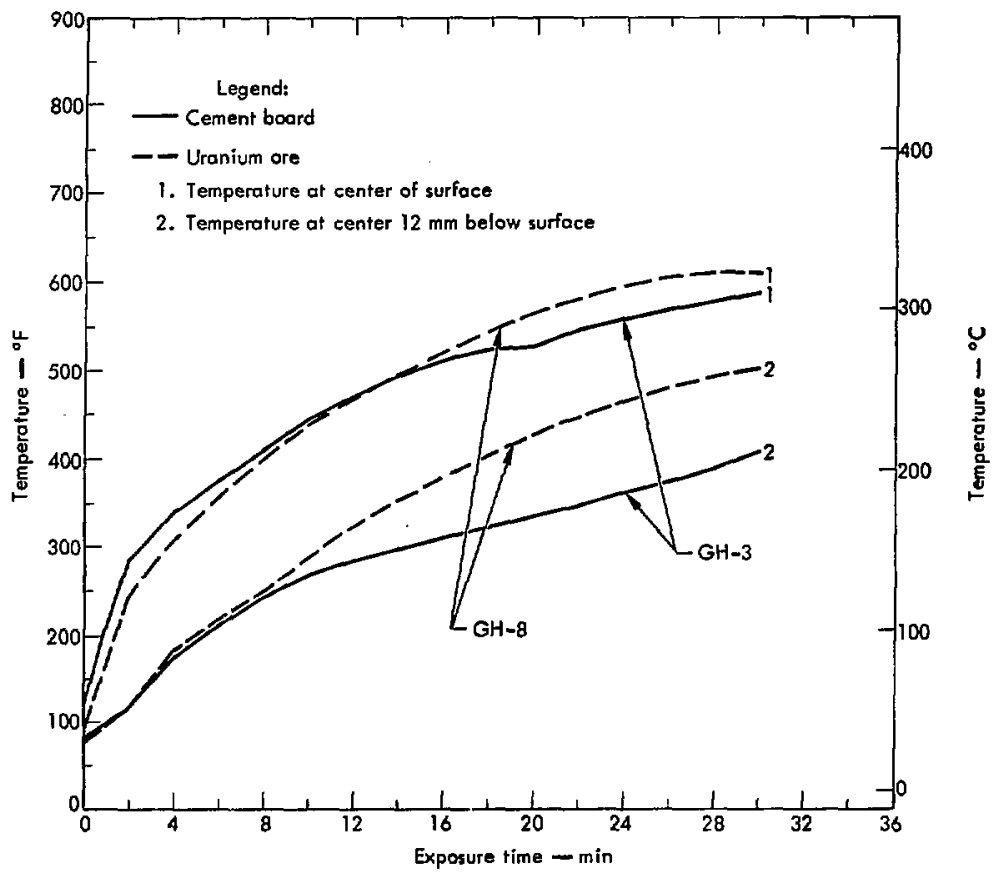

Fig. A-4. Surface and body temperatures of cement-beard and uranium-ore squures whose front surface had been coated with 10 mils of HydrEpoxy 300 . The squares were exposed to $2.5 \mathrm{~W} / \mathrm{cm}^{2}$ radiant heat. without pilot flame. 


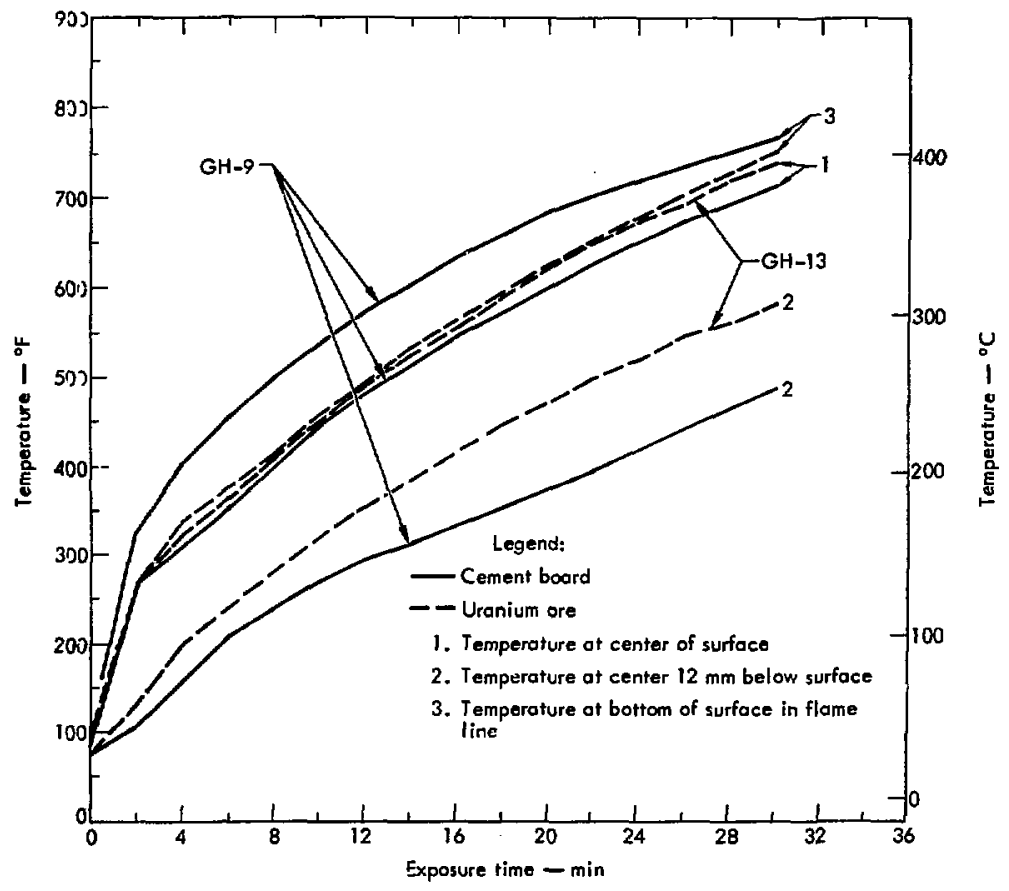

Fig. A-5. Surface and body temperature of cement-buard and uranium-ore squares whose tront surface was coated with 10 mils of Saran XD.7151. Tlee squares were exposed to $2.5 \mathrm{~W} / \mathrm{cm}^{2}$ radiant heat with pilot flane. 


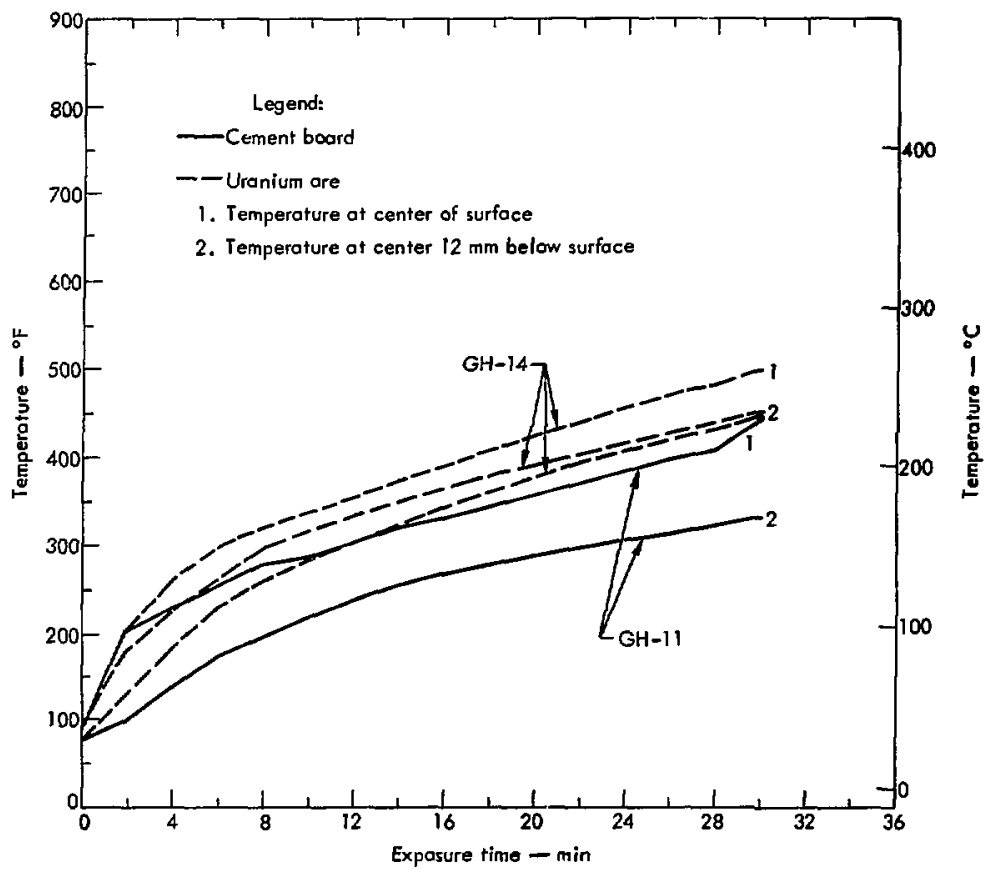

Fig. A-6. Surface and body temperature of cement-board and uranium-ore squares whose front surface was coated with Saran XD-7151. The squares were exposed to $2.5 \mathrm{~W} / \mathrm{cm}^{2}$ radiant heat. without pilot flame. 


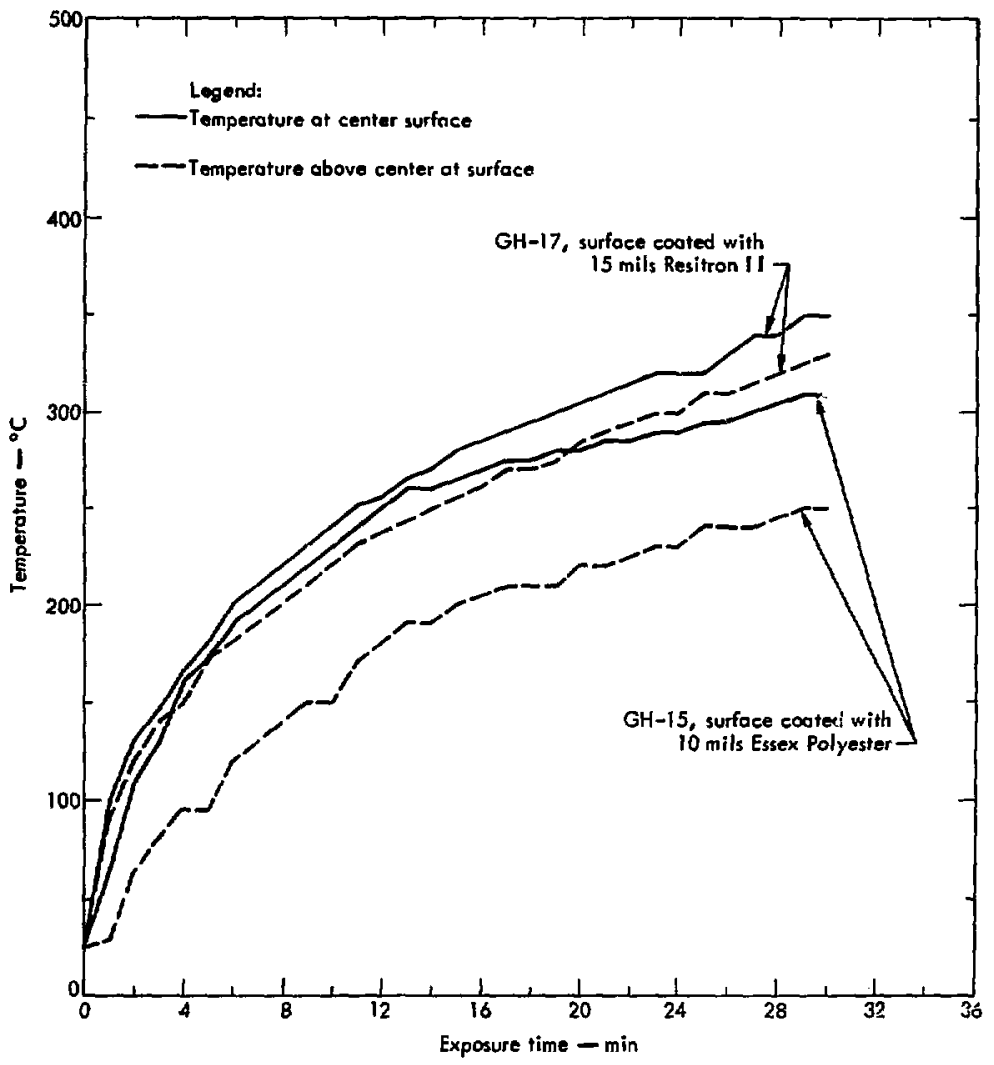

Fig. A-7. Surface and body temperature of sample exposed to $2.5 \mathrm{~W} / \mathrm{cm}^{2}$ radiant heat without pilot flame. 


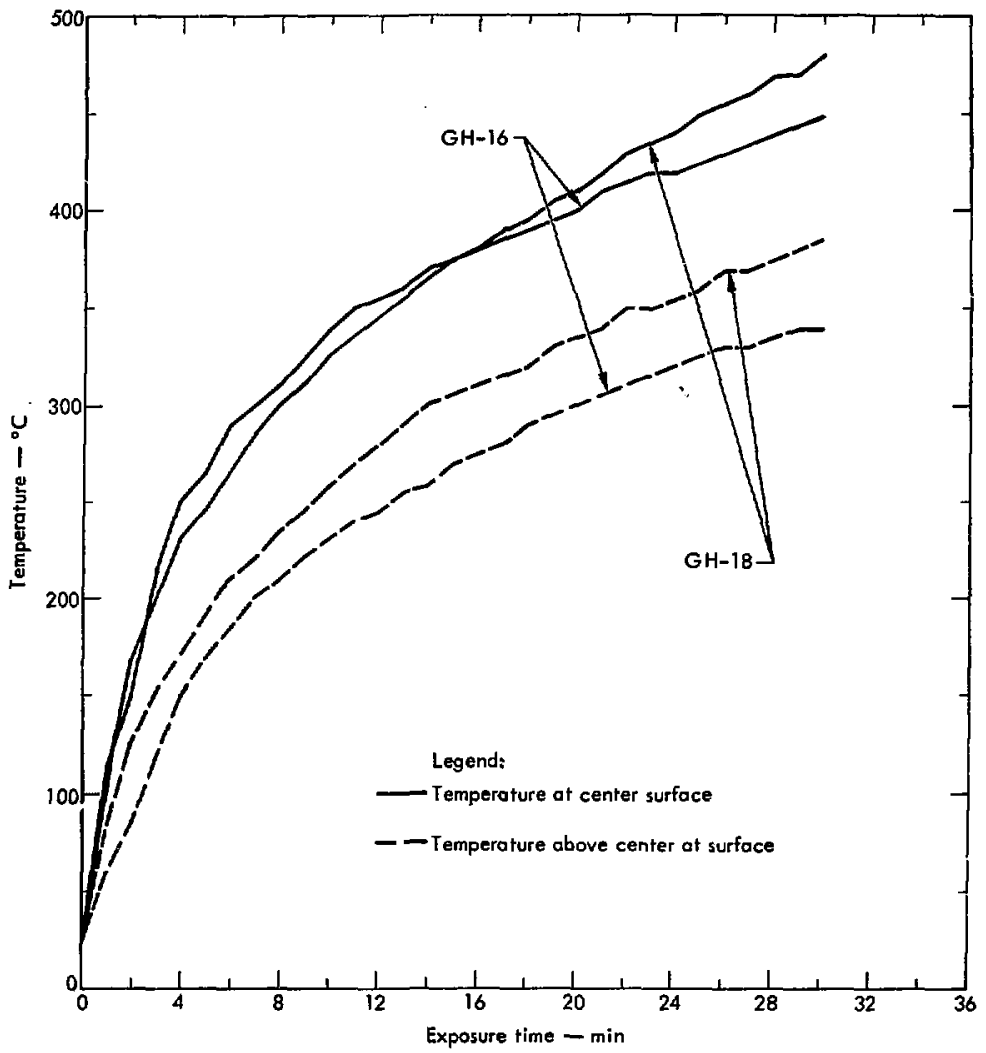

Fig. A-8. Surface and body temperature of sample exposed to $2.5 \mathrm{~W} / \mathrm{cm}^{2}$ radiant heat with pilot flanre. 


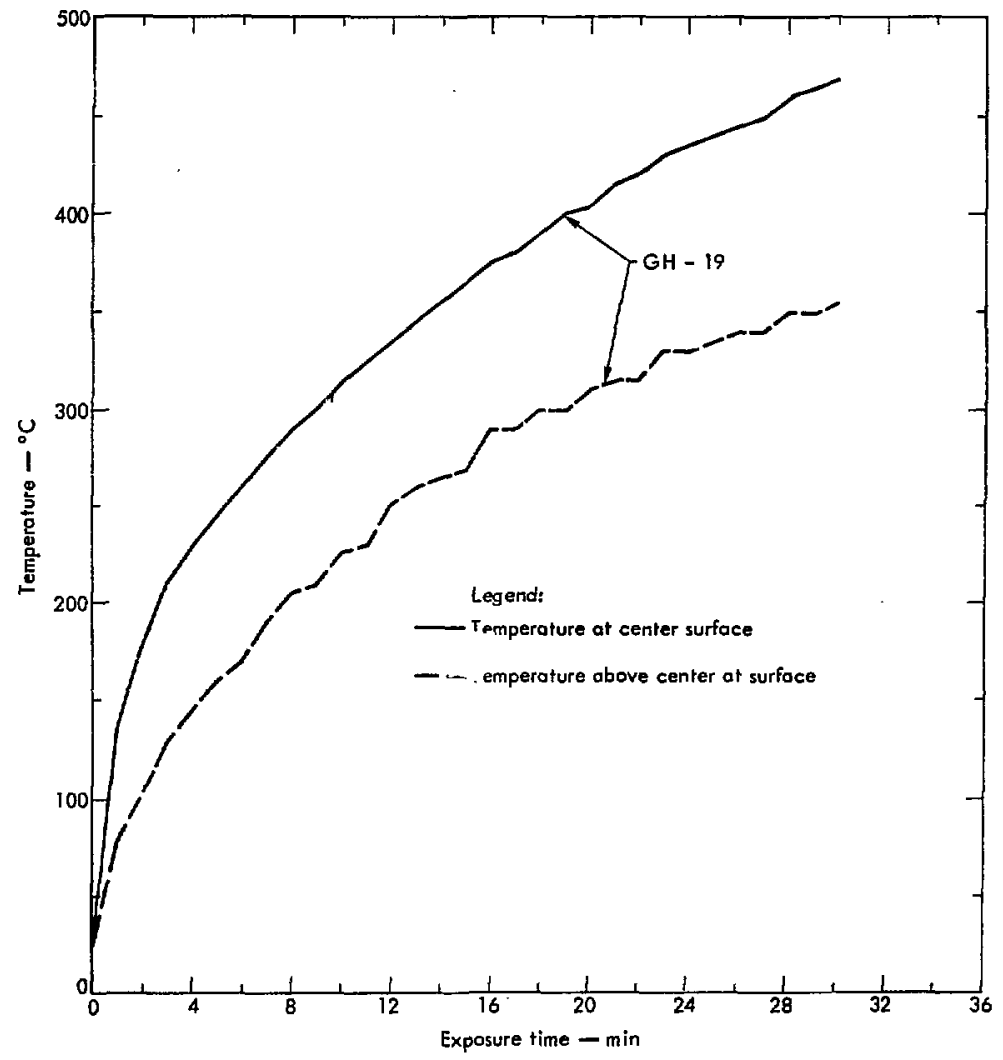

Fig. A-9. Surface and body temperature of sample GH.19, surface coated with 20 mils Resitron Il and exposed to $2.5 \mathrm{~W} / \mathrm{cm}^{2}$ radiant heat with pilot flame. 


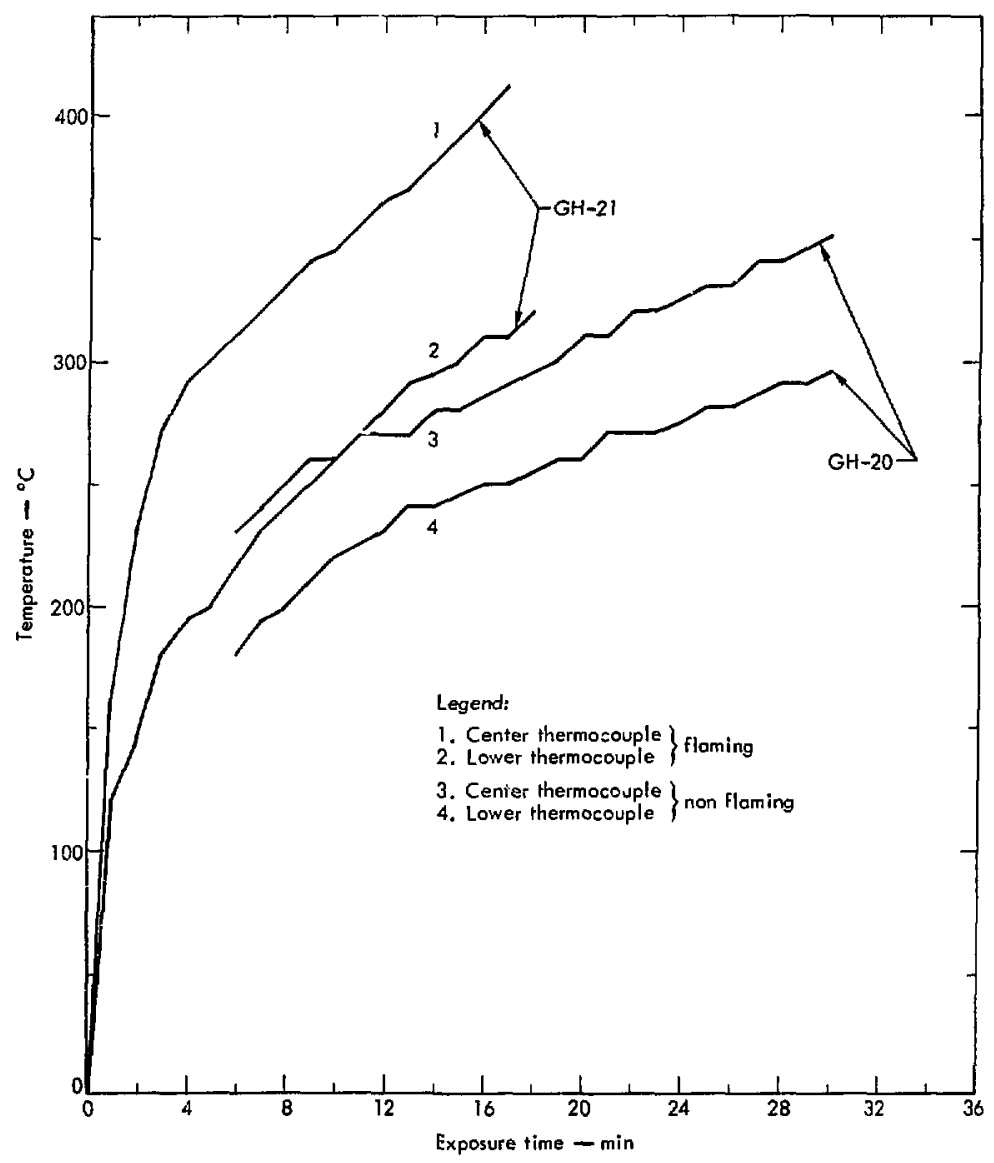

Fig. A-10. Surface and body temperature of a sample whose surtace was coated with WSU.1 18 und exposed to $2.5 \mathrm{~W} / \mathrm{cm}^{2}$ radiant heat with and without flame. 


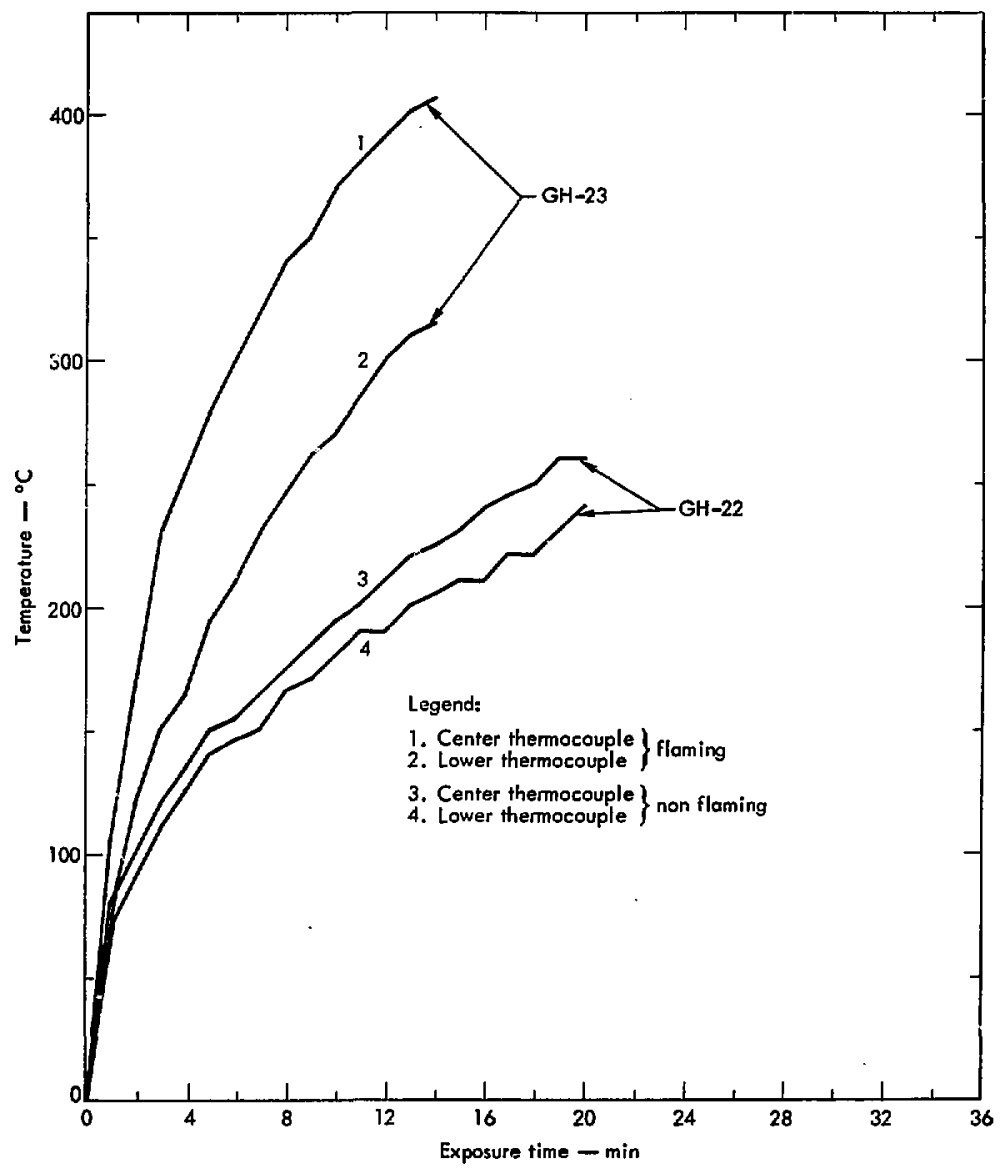

Fig. A-11. Temperatures recorded at the center and lower thermocouple of a sample coated with Aerospray 70 and exposed to $2.5 \mathrm{~W} / \mathrm{cm}^{2}$ of radiant leeat witl and without flame. 


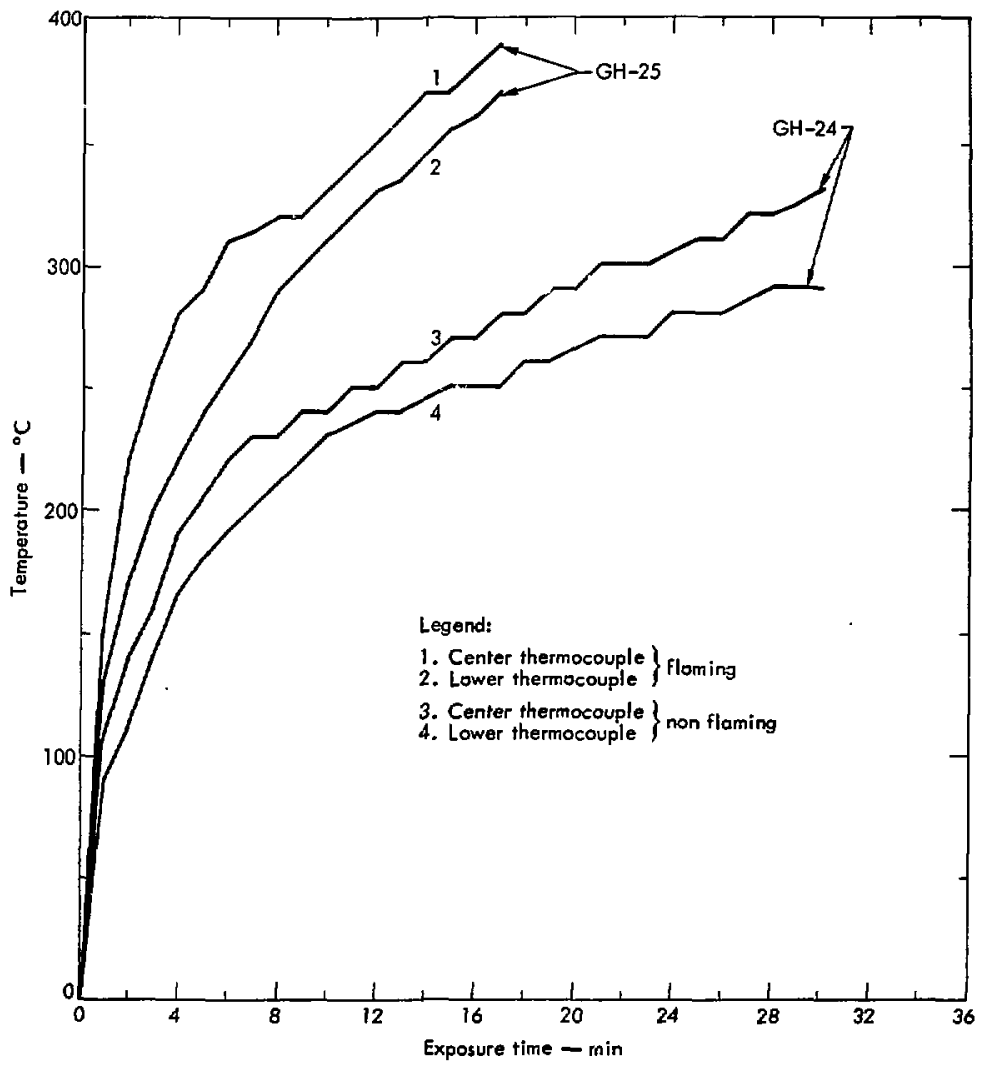

Fig. A-12. Temperatures recorded at the center and lower thermocouple of a sample coated with EpiRe: WD-510/ EpiCure 872 and exposed $102.5 \mathrm{~W} / \mathrm{cm}^{2}$ of radiant heat with and without flame. 


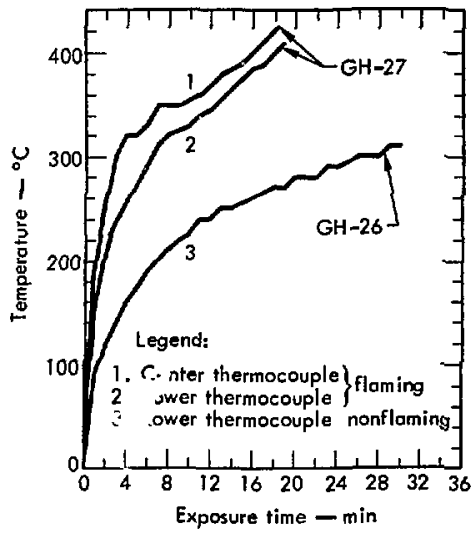

Fig. A-13. Teniperatures recorded at the center ind lower thermocouple of a smple couted witl EpiRez WD-510/EpiCure 872 and 879. The sample was exposed to $2.5 \mathrm{~W} /$ $\mathrm{cm}^{2}$ of radiant heat with and willout f]:มנse.

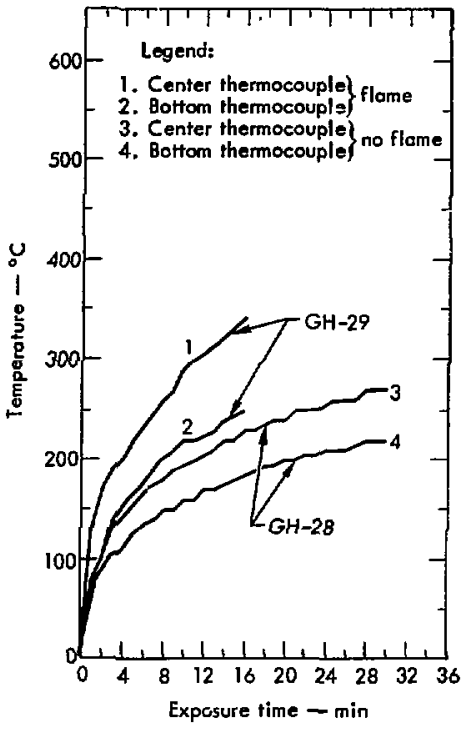

Fig. A-14. Temperatures at the center and bottom of samples coated witin Promulsion 200. 


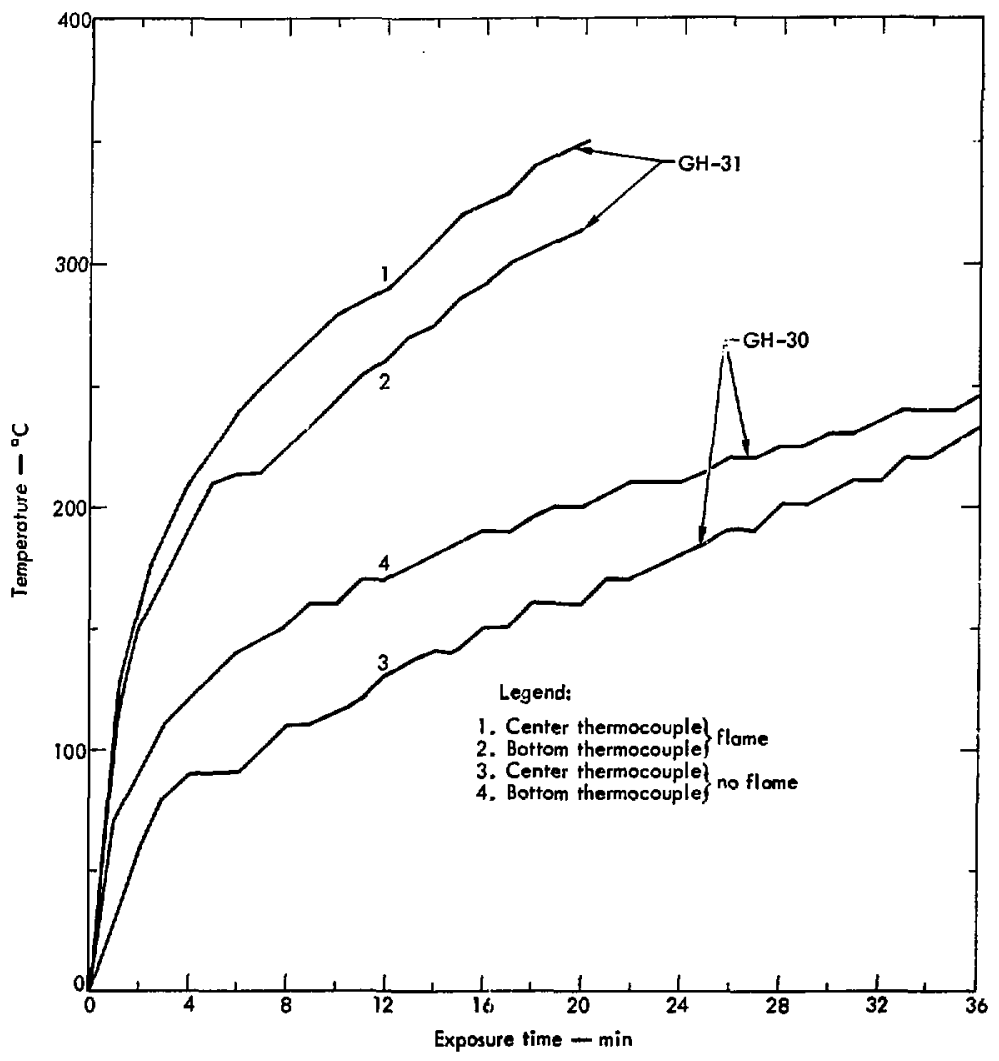

Fig. A-15. Temperatures at the center and buttom of samples toated with Hydro Seal. 


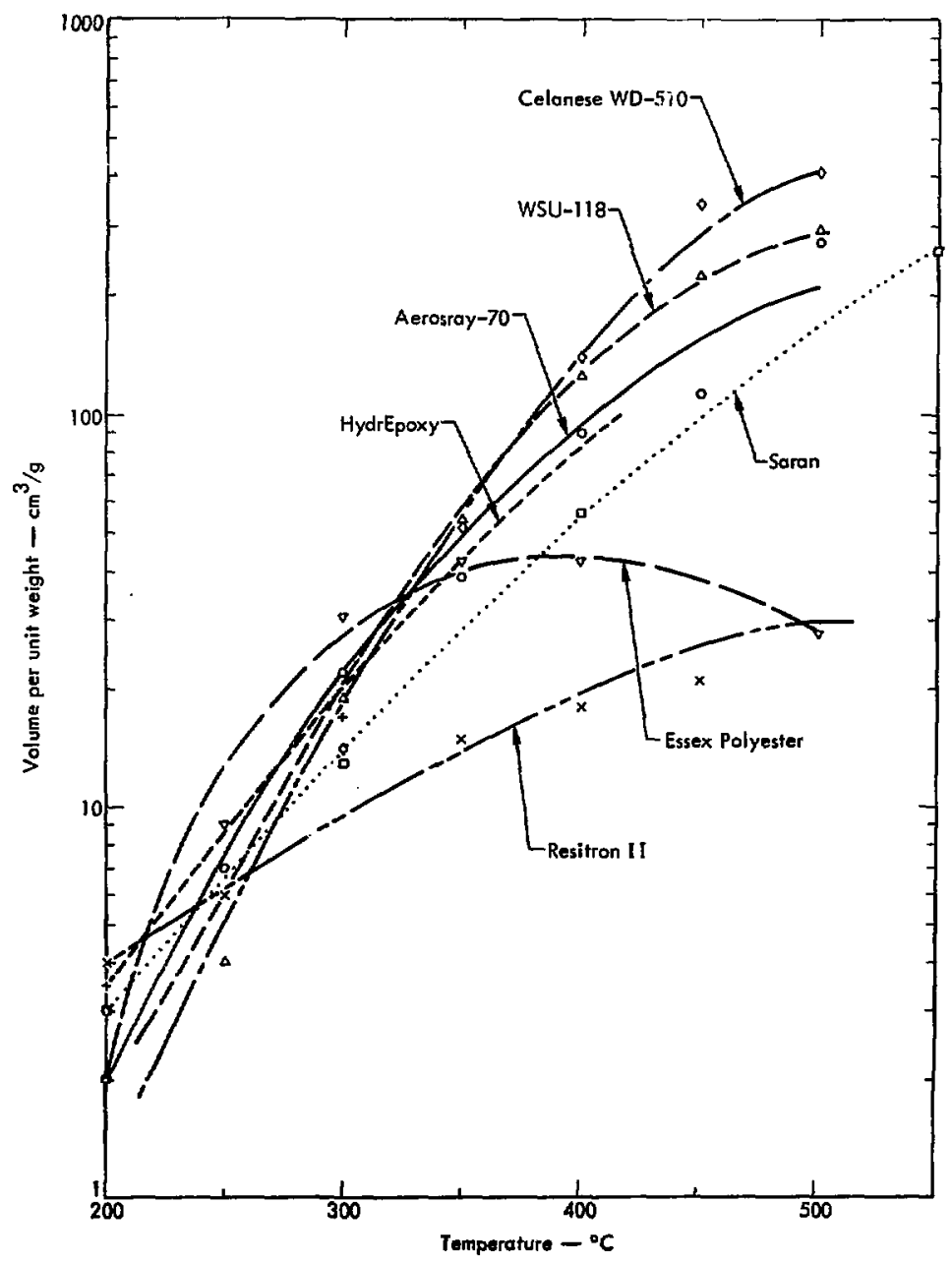

Fig. A-16. Carbon monoxide evolution. 


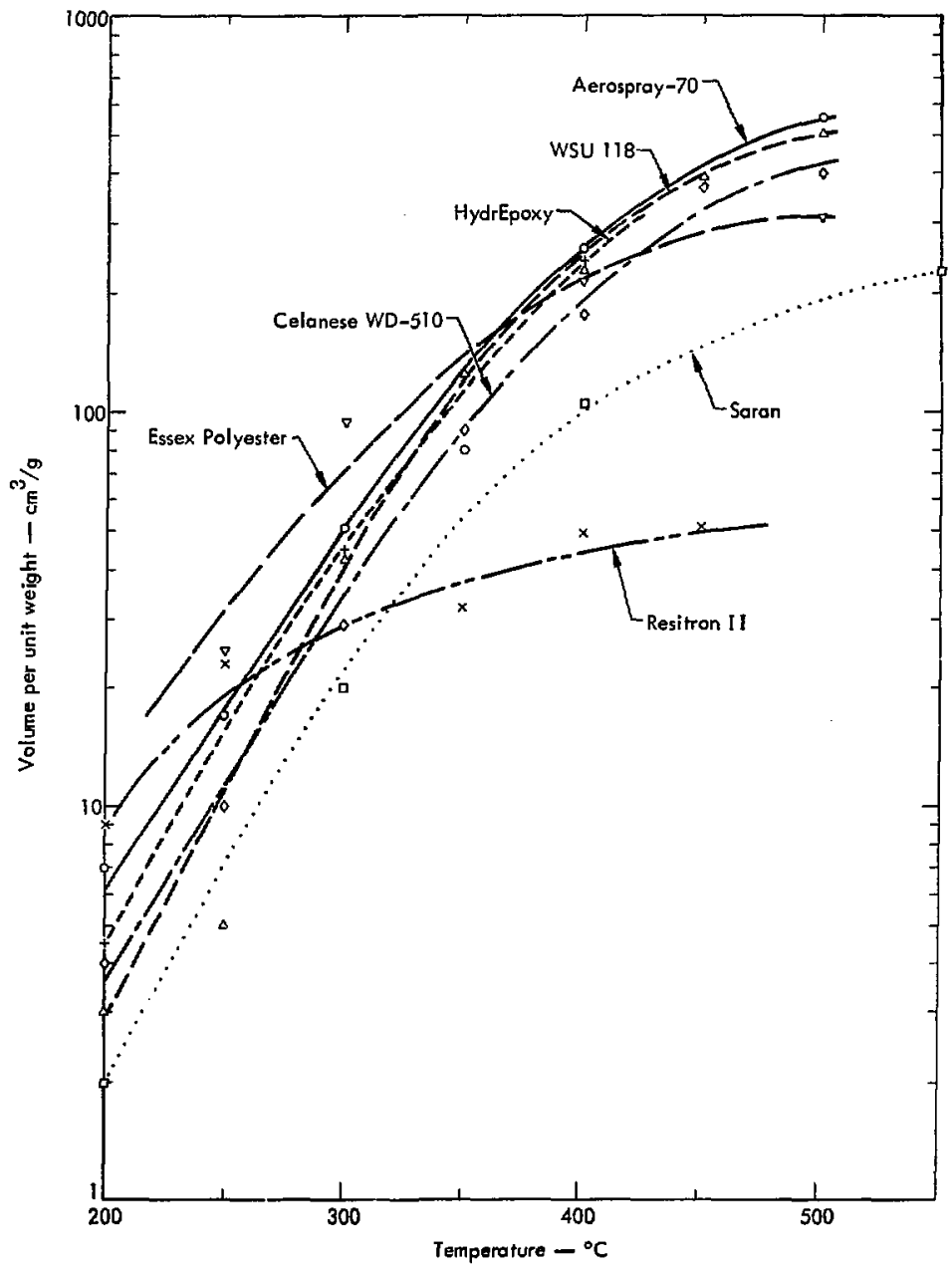

Fig. A-17. Carbon dioxide evolution. 


\section{Appendix B: \\ Computer Program (PDP-8) for Calculation of Permeability Coefficients from Dow Cell Data}


- H Finir

?06. 900

$* \mathrm{~b} A$

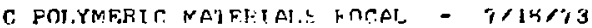

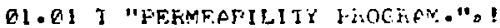

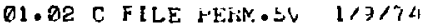

Q1.03 T "FNTEh UNIIS FEN ASIN-I-1434-66 MFIHOL M.", It

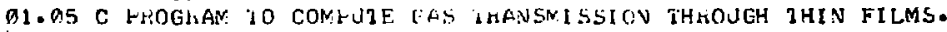

D. 1 . CHANGE LATF, \&-1\%-7:3

01.10 S $A=1.872$.

A1.20 S $A T=63 \cdot 62$

01.30 A "H $(M M)=", H$

$01.40 \mathrm{~S} \quad \mathrm{MP}=65.5$

(1.50 S HL $=65.5$

01.60 A "F (MMHG) $=", \mathrm{~F}$

61.7ด $5 \quad T=296$

$01.8(A$ A "VF $(M M+3)=", V F$

01.90 A "HIC $(M M H G / I N-1)=", \mathrm{KC}$

01.95 A "BTP (IN,A S $="$, SiP

91.96 5 ? $1=0$

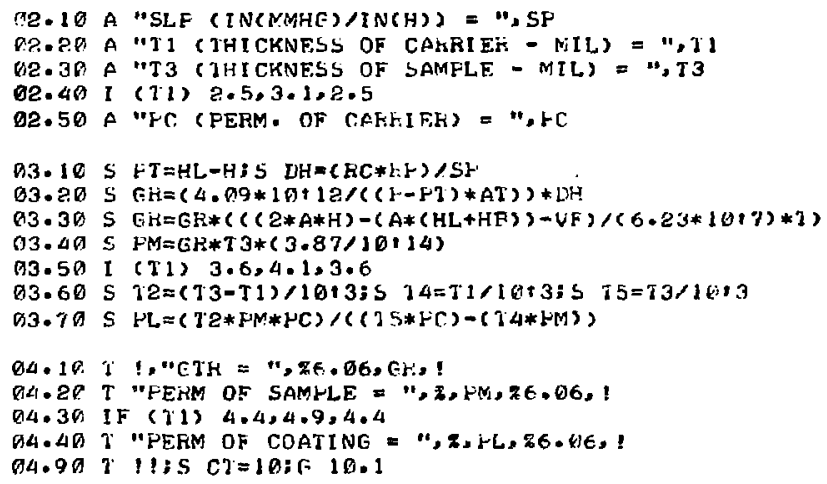




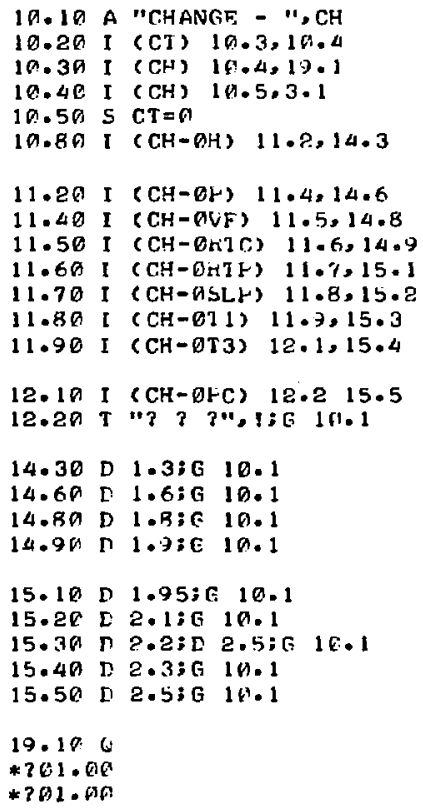




\section{Appendix C:* \\ Direct Determination of Radon Permeability \\ Through Polycarbonate Film}

In connection with the program to find sealants for uranium mine tunnels. In experinent to determine the permeation of radon.222 through polycurbonate (PC) film was perforıned. The cell used in the experiment is shown in Fig. C-I.

The two halves of the cell were constructed of $80 \cdot \mathrm{mm}$ Pyrex glass tubing. This tubing has an inner diameter of $74 \mathrm{~min}$ and the exposed area of the membrane inounted between the two lyalves was thus $43 \mathrm{~cm}^{2}$. The volume of the upper half of the cell was about $200 \mathrm{~cm}^{3}$ and the lower half about $20 \mathrm{~cm}^{3}$. The flanges of the ce: were greased with Apiezon $N$ and a square portion of the membrane about $10 \mathrm{~cm}$ on a sille inounted between them. The two halyes of the cell were wired together and then simultaneously evacuated to check that a vacuumn-tight seal had been obtained. Once this was confirmed, air was simultaneously admitted to the two halves of the cell to a pressure of about $70 \mathrm{~cm} \mathrm{Hg}(93 \mathrm{kPa})$.

A flask of about $400 \mathrm{~cm}^{3}$ volume containing about $100 \mathrm{~cm}^{3}$ of a solution of about $10^{9}$ DPM of radon-226 had been previously evacuated and allowed to stand for a month until the 3.8-day radon-222 had grown into equilibrium. The flask was attached to the vacuum manifold and filled with air to a pressure of about $70 \mathrm{~cm} \mathrm{Hg}$ $(93 \mathrm{kPa})$. Subsequent to the experiment. sjmples of the gas were taken and the atoms of radon-222 per unit volume determined by alpha-counting.

The experinent was initiated by attaching the radon-226 flask to the lower cell and opening stopcocks to admit the radon-222 to the lower side of the membrane. Initially both halves of the cell contained a total pressure of about $70 \mathrm{~cm} \mathrm{Hg}$, and once radon-222 air diffusion from the flask to the lower cell was complete, the "pressure" of radon-222 on the lower side of the cell would be constant.

Referring to Fig. C-I, helium from the upper left port was periodically flushed through the upper cell and into the U-trap packed with molecular sieve 5A. The MS5A trap was cooled in liquid nitrogen during these sampling operations. Pumping on the trap exit at upper rigit inaintained pressure at $96 \pm 1.3 \mathrm{kPa}$. While there is no stable isotopic carricr for radnn-222, ethane has similar adsorption characteristics on MS5A. Approximately $30 \mathrm{~cm}_{\mathrm{STP}}^{3}\left(0^{\circ} \mathrm{C}, 101 \mathrm{kPa}\right)$ of ethane were added to each collected radon-222 fraction and the mixture desorbed at $350^{\circ} \mathrm{C}$ into a liquid nitrogen cooled trap. Counting tubes were calibrated on the alpha plateau using the radon-222 at equilibrium with a known amount of radon-226. By expanding a known amount of the radon-222 ethane mixture into one of these tubes and counting radon.222, one deternines the radon.222 per unit volume of mixture. From the known total of the inixture one then calculates total radon-222 in the sample. Measurements were made at least in duplicate. The percent errors quoted in the table of results are standard deviations based on the differences among replicates.

The experiment extended over a periad of 32 days during which 14 collections of radon-222 from the upper cell were inade. The results are given in Table C-L. Columns 1 und 2 list sumple number and sampling time. Column 3 gives the number of atoms in the sample at sampling tinie per $\mathrm{cm}^{2}$ ol exposed membrane. As noted above, this area was $43 \mathrm{~cm}^{2}$. Column 4 gives a cumulative total obtuined by sununing the atoms per $\mathrm{cm}^{2}$ in the latest sumple and those in all previous sumples decay-corrected to the latest time of sumpling. These results are thus the total which would have been observed in the sample if no prior sample had been taken. It will be seen later that this is one of the easier quantities to calculate theorectically. The half-life of radon-222 was taken as 3.82 days. Columns $S, 6$, and 7 will be elucidated later.

The work reported in this section was done and reported by Floyd Momyer. 


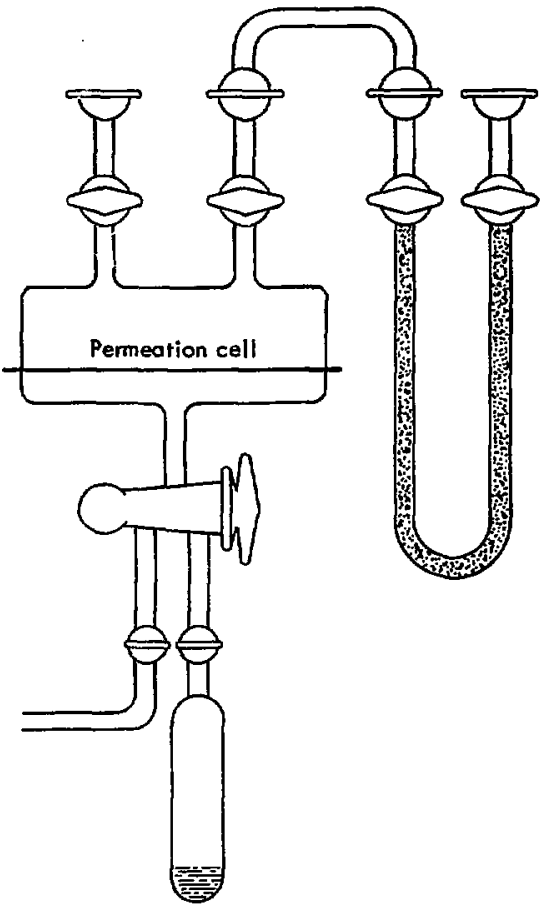

Fig. C-1. Schematic of radon.222 permeation cell and experimental setup. 
Table C-1. Results for Radon-222 Permeation Through Polycarbonate., d,

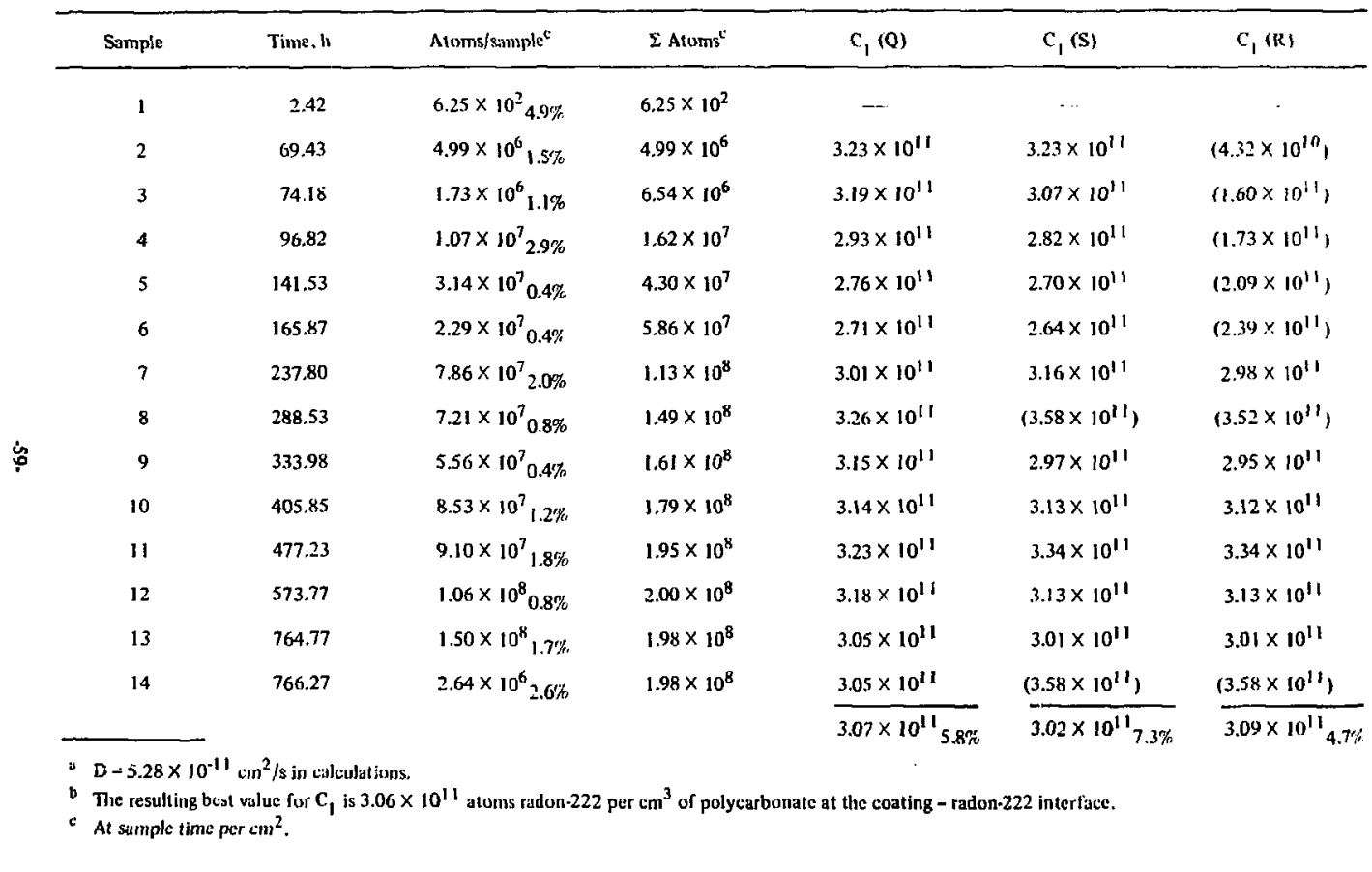


If the concentration in the membrane is given by a function $C(x, t), t)$ en for a stable species ine boundary value problem we are interested in is:

$$
\begin{aligned}
& \frac{\partial C}{\partial t}=D \frac{\partial^{2} C}{\partial x^{2}} \\
& C(x, 0)=0,0<x<\ell \\
& C(0, t)=C_{1} \text {, all } t \\
& C(\ell, t)=0, \text { all } t
\end{aligned}
$$

In the above, $x=$ distance into the film, $Q=$ total thickness of the film, $t=$ time, $D=$ the diffusion constant of the species in the inembrane, $\mathrm{C}(x, t)=$ atoms per unit volume of membrane at given $x$ and $t$, and $C_{1}$ is the (constant) concentration in the membrane at the $x=0$ interface.

If one assumes that $C_{1}$ is proportional to pressure (Henry's law), then $C_{1}=K P$, where $C_{1}$ is the concentration in $\frac{\mathrm{cm}_{\mathrm{STP}}^{3}{ }^{222} \mathrm{Rn}}{\mathrm{cm}^{3} \text { membrane }} . P$ is the pressure of radon-222 on the upstream side in $\mathrm{KPa}$, and $\mathrm{K}$ is the solubility (Henry's law constant) in units of $\frac{\mathrm{cm}_{S T P}^{3}}{\text { of }{ }^{222} \mathrm{Rn} / \mathrm{cm}^{3} \text { membrane }}$.

If we call this solution $C^{0}(x, t)$, then:

$$
C^{0}(x, t)=C_{1}\left(1-\frac{x}{l}\right)-\frac{2 C_{1}}{\pi} \sum_{n=1}^{\infty} \frac{1}{n} \sin \frac{n \pi x}{l} e^{-\frac{D n^{2} \pi^{2} t}{l^{2}}} .
$$

However, for a radioactive species the decay law says $\mathrm{dN} / \mathrm{dt}=-\lambda \mathrm{N}$, where $\mathrm{N}$ is the number of atoms present at a given time. and $\lambda$ is the disintegration constant of the diffusing species. Thus, if $C(x, 1)$ is the number of atoms $\rho e r$ unit volume present in the membrane, the differential Eq (1) must be modified to

$$
\frac{\partial C}{\partial t}=D \frac{\partial^{2} C}{\partial x^{2}}-\lambda C
$$

The other conditions remain the sume. Following Carslaw and Jaeger"

$$
C(x, t)=\lambda \int_{0}^{t} e^{-\lambda t^{\prime}} C^{0}\left(t^{\prime}\right) d t^{\prime}+C^{0} e^{-\lambda t},
$$

where $C^{0}(x, 1)$ is the function given above, and $z^{\prime}$ is a variable of integration.

The result of this integration is

$$
C=C_{1}\left(1-\frac{x}{Q}\right)-\frac{2 C_{1} \lambda \ell^{2}}{D \pi^{3}} \sum_{n=1}^{\infty} \frac{1}{n} \sin \frac{n \pi x}{Q}\left\{\frac{1+\frac{D \pi^{2} n^{2}}{\lambda l^{2}} e^{-\left(\frac{D \pi^{2} n^{2}}{R^{2}}+\lambda\right) t}}{n^{2}+\frac{\lambda l^{2}}{D \pi^{2}}}\right\} \text {. }
$$

*H.S. Carslaw and J.C. Jaeger, Conduction of Heat in Solids (Oxford Press, 1959) p. 33; also Danckwertz, Trans. Faraday Soc. 47 (1951) 1014.23. 
Also if $q$ is the rate of passuge of atoms across the pluse at $x$, then

$$
q=-D \frac{\partial C}{\partial x}
$$

and

$$
q=\frac{D C_{1}}{l}+\frac{2 C_{1} \lambda R}{\pi^{2}} \sum_{n=1}^{\infty} \cos \frac{n \pi x}{l}\left\{\frac{1+\frac{D \pi^{2} n^{2}}{\lambda R^{2}} e-\left(\frac{D n^{2} n^{2}}{Q^{2}}+\lambda\right) t}{n^{2}+\frac{\lambda R^{2}}{D \pi^{2}}}\right\} .
$$

The above equation is, of course, generally evaluated at $x=\ell$ where $\cos \frac{\pi \pi x}{l}=(-1)^{n}$. It should be noted at this point that for $\lambda=0$ the late time rate of permeation at $x=\ell$ is sinsply

$$
(\mathfrak{d})_{\mathrm{x}=\ell}=\frac{D C_{1}}{\ell} \text {. }
$$

However, for a finite disintegration constant, at late times

$$
(q)_{x=\ell}=\frac{D C_{1}}{\ell} \cdot \frac{\sqrt{\frac{\lambda}{D}} \cdot \ell}{\sinh \left\{\sqrt{\frac{\lambda}{D} \cdot \ell}\right.} .
$$

Evaluation of the series in the second member on the right shows this member to be always negative. In fact, depending upon values of $D, \lambda$, and $Q$ the first and second members may be comparable in absolute value. One may think of this as meaning that, on the average, the time an atom spends in the membrane after leaving the constant source of supply and befrre emerging on the other side may be significant compared to its radioactive lifetime. Unfortunately, this "holdup" time does not appear to be a very simple function of the parameters involved. However, the result is that the effect of a membrane in reducing downstream concentration of a radioactive species is always cnhanced by radioactive decay - and this effect may be quite significant. The late-time rate of permeation is still a simple linear function of $C_{1}$; however, it is no longer inversely proportional to thickness but decreases more strongly witt increase in thickness. The product of solubility and diffusion constant no longer de termines late-time rate of permeation. Unless films having extremely low solubility are found, the diffusion constant alone is the critical parameter.

Tn proceed with the solution of the boundary value problem, observations were actially made on the amount of radon-222 existing on the downstream side at various times. If the anount having crossed the plane $\mathrm{x}$ and existing at a time $\mathbf{T}$ is $\mathbf{Q}$, then

$$
Q=\int_{0}^{T} \mathrm{q}(\mathrm{t}) \mathrm{e}^{-\lambda(\mathrm{T}-\mathrm{t})} \mathrm{dt}=e^{-\lambda T} \int_{0}^{\mathrm{T}} \mathrm{q}(\mathrm{t}) \mathrm{e}^{\lambda t} \mathrm{dt} .
$$

The result of this integration is

$$
Q=\frac{D C_{1}}{\lambda \ell}\left(1-\mathrm{e}^{-\lambda T}\right)+\frac{2 C_{1} \ell}{\pi^{2}} \sum_{n=1}^{\infty} \cos \frac{n \pi x}{l}\left\{\frac{\left.1-e^{\cdot\left(\frac{D \pi^{2} n^{2}}{\ell^{2}}+\lambda\right)}\right) T}{n^{2}+\frac{\lambda \ell^{2}}{D \pi^{2}}}\right\} .
$$


Again, at late time and for $x=\ell$ the total radon-222 existing on the far side of the film is

$$
(Q)_{x=\ell}=\frac{D C_{1}}{\lambda \ell} \cdot \frac{\sqrt{\frac{\lambda}{D}} \cdot \ell}{\sinh \left\{\sqrt{\frac{\lambda}{D}-\ell}\right.} \text {. }
$$

Thus, not only the rate of permeation eventually becomes constant, but the total radon-222 existing on the downstream side of the membrane is constant. It will also be noted that $(q)_{x=\ell}=\lambda(Q)_{x=\ell}$ at late times, as it should when the rate of entrance into the downstream region finally equals the rate of decay of those atoms already downstream.

Before attempting interpretation of the results, several comments on departures from the theory on which the interpretation will be based should be made. While in principle these departures are all correctable, it was decided to design the experiment on the basis of convenience and maximum utilization of existing equipment with the aim of obtaining results uncertain by less than the factor of two that we understood wa: acceptable.

The rirst vinlation of the boundary conditions used in the solution of the differential equation for the permeation process is that the concentration of radon-222 on the upper side of the membrane is not always zero. Intuitively, one would expect that after a long interval between samplings the observed rate of permeation would be depressed and thit a period of increased permestion would follow sampling. It will be seen that the next-tolast sampling interval was nearly $200 \mathrm{~h}$ and the last $1.5 \mathrm{~h}$. While the last sample does indeed show an increased rate of permeation beyond analytical error, the effect is in any case less than $20 \%$.

The temperature was not rigorously controlled in the box containing the equipment. However, periodic logging of the box tomperature indicated that it remained within the range $(21 \pm 2)^{\circ} \mathrm{C}$.

At the initiation of the experiment. the pressure at the lower side of the membrane was not constant until interdjffusion of air and radon-222 was complete in the lower cell. Since this process should take hours and the experiment ran hundreds of hours this was considered acceptable.

Similarly. the reduction of radon-?22 pressure in the radon-226 flask by an initial sampling operation was considered acceptable on the time scale of the experiment since equilibrium would be reestablished to within a fraction of a percent within a week.

One worries about the possibility of pinholes in the membrane, also the $10^{9}$ DPM solution of radon-226 was at least connected to the vacuusn system to fill it with air prior to the experiment. Although care was taken in this operation, thr wossibilit. of tontamination in the vacuum system could not be ruled out. The first sample at $2.42 \mathrm{~h}$ was tol.tn as a check on these possibilities. Theory says thete should be no detectable radon-222 in this sample. Whether the value reported is real is not unambiguous since the observations in the counting tubes were a few tenths of a count per minite over about one count per minute background. In any case, the observed amount is 4 orders of mugnitude less than that in any subsequent sample. Thus leaks or contamination appear to have been at acceptable leveis.

There are a number of wa; $s$ in which one cin handle the results of this experiment.

Method I

In the first pluce. as was done in Table $\mathbf{C}-\mathbf{I}$, one can sum all samples suitably decay-currected to oblain the total permeation at the time of a given sample. This has no advantages. Inspection of the equation for $(Q)_{x=\ell}$ 
indicates that at late times $Q$ becomes an approximately lineas function of the parameter $\tau=1-e^{-\lambda T}$. If $\tau^{0}$ is the intercept of this line with the $\tau$ axis, then

$$
D=\frac{2 \ell^{2} \lambda}{\pi^{2} \tau^{0}} \sum_{n=1}^{\infty} \frac{(-1)^{n}}{n^{2}+\frac{\lambda l^{2}}{D n^{2}}} .
$$

Such a plot was indeed made on data from the last eight samples to obtain a least-xquares fit for the late $Q=0$ intercept, and a value of $D$ was calculated from this intercept.

Once the value of $D$ is known it will be seen that the data from the experiment can be used to detive a value of $C_{1}$ from total permeation at each sampling. Since $C_{1}$ is assumed to be a constant, the above value obtained graphically for $D$ was taken as the starting point for an iterative routine on $D$ that resulted in the least sum of squares about the mean for $C_{1}$ for all but the initial sample. This process resulted in a value for $D$ about $10 \%$ lower than the original estimate. Figure C-2 presents the data as a function of $\tau$. The theoretical curves (solid lines) are from the result for $D$ of the iterative process.

The second advantage of this mode of presentation is that the results should be a smooth curve plotted against time which can be compared with a theoretical curve. Figure C-3 is a plot of the experimental data compared to a theoretical curve derived from final values of the parameters $D$ and $C_{1}$.

It might be noted that for $D=5.28 \times 10^{-11} \mathrm{~cm}^{2} / \mathrm{s}$, the average for $C_{1}$ in 12 samples is $3.06 \times 10^{11} 5.8 \%$. If $\mathrm{D}$ is increased $10 \%, \mathrm{C}_{1}$ from these same samples is $2.39 \times 10^{11} 11.3 \%$, and individual values show a distinct upward trend with increasing sampling time. Decreasing $D$ by $10 \%$ results in $C_{1}$ equal to $4.15 \times 10^{11} 14.3 \%$ and a downward trend with increasing time.

The disadvantage of this procedure is that an error in any one of the previous samples will be propagated until radioactive decay has reduced it to insignificance.

\section{Method 2}

The data cun also be used to calculate a value of $\mathrm{C}_{1}$ from the number of atoms in each sample. Thus, if $s$ refers to the number of the sample,

$$
Q_{s}=Q_{T_{s}}-Q_{T_{s-1}} e^{-\lambda\left(T_{s}-T_{s-1}\right)} \text {. }
$$

Regarding the data in this manner suggests that sample 8 is too high by about $15 \%$, probably due to an ertor in the amount of ethane carrier added to the radon-222. Results from the other data would allow correction for this, and such calculations were performed. Since they made less than $1 \%$ difference in the final conclusions, the data are presented as obtsined. Such an error is considered insignificant compared to other uncertaintios in the experiment.

\section{Method 3}

A third method of treating the data is suggested by noting that once the rate of permeation $(q)$ is constant, the radon-222 in each sample satisfies the equation

$$
q=\frac{\lambda Q_{s}}{1-e^{-\lambda\left(T_{s}-T_{s-1}\right)}} .
$$

Thus, once the value of $D$ has been determined, a value of $C_{1}$ can again be calculated from the resilt of each sampling. 


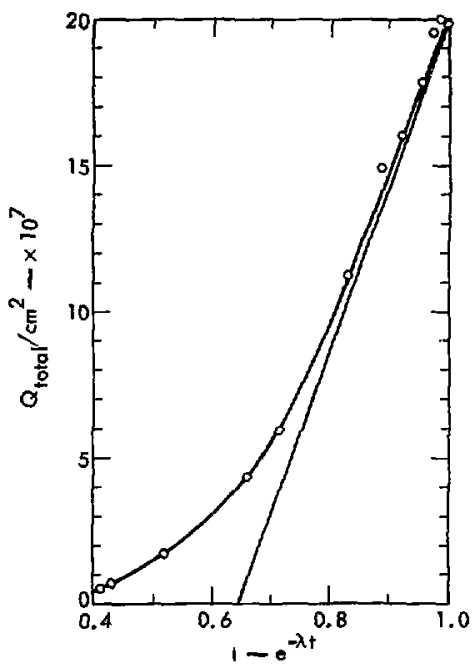

Fig. C-2. Total permeation vs $1-e^{-\lambda t}$

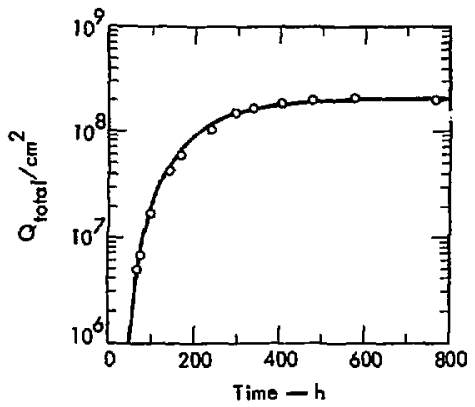

Fig. C-3. Total permeation vs time. 
It might be noted that once steady-siate has been achieved. methods two and threc are equivalent in principle.

For purposes of data reduction, a program was written for tlie CDC 7600 which would salculate $q / C_{1}$ and $Q / C_{1}$ at $x=\ell$ as a function of $\lambda$. D. $R$. and $t$. The disintegration tonstant. $\lambda$, was taken throughout as $7.55 \times 10^{-3} \mathrm{~h}$. At arly times all of these series. particulorly that for $q$. are nut very well behaved. Thus. calculations on $q$ at early times are suspect both for calculational reasons and the fact that $q$ is actually increasing during the early sampling intervals, All values of rate of permeation calculated will be 100 small. and yield a low value for $\mathrm{C}_{\mathbf{1}}$. Although fewer terms would suffice in most instances, calculations were rather arbitrarily based on the furst 5000 terms of each of the series since this required only about a second of computer time.

Referring back to Table $C-1$, column 5 lists derived values of $C_{1}(Q)$ based on method $I$ above, or total permeation to sample time. Column 6 lists values of $C_{1}(s)$ based on method 2 or the permeation in each ample. Column 7 lists values of $C_{1}$ derived from method 3, or rate of permeation during each interval. It will be noted that the values in column 7 are indeed less than those in column 6 a1 early times, and later approach them almost exactly. Parenthesized values were not used in calculating quoted averages.

The samples taken at the end of the experiment indicated $1.09 \times 10^{10} 1.5 \%$ atoms of radon-222 per $\mathrm{cm}^{3}$ of flask volume or a pressure of radon-222 $=4.44 \times 10^{-5} \mathrm{~Pa}$ at $21^{\circ} \mathrm{C}$. For $\mathrm{D}=5.28 \times 10^{-11} \mathrm{~cm}^{2} / \mathrm{s}$, the value, $C_{1}$, of the concentration in the membrane it $x=0$ is $3.06 \times 10^{13}$ atoms ${ }^{222} \mathrm{Rn} / \mathrm{cm}^{3} \mathrm{PC}$ or $1.138 \times 10^{-8} \mathrm{~cm}_{\mathrm{STP}}^{3}{ }^{221} \mathrm{Rn}$ per $\mathrm{cm}^{3}$ of PC. Assuming Henry's law.

$$
\mathrm{C}_{1}=\left(0.257 \frac{\mathrm{cm}_{\mathrm{STP}}^{322} \mathrm{Rn} / \mathrm{cm}^{3} \mathrm{PC}}{\mathrm{kPa}{ }^{222} \mathrm{Rn}}\right) \times \mathrm{P}(\mathrm{kPa}) \text { of }{ }^{222} \mathrm{Rn} .
$$

Alternatively,

$$
\frac{\text { atoms }{ }^{222} \mathrm{Rn}}{\mathrm{cm}^{3} \mathrm{PC}}=28.0 \times \frac{\text { atoms }}{222 \mathrm{Rn}} .
$$

To illustrate the effect of radioactive decay, one may use $\mathrm{Eq}(8)$ to calculate late time permeation as a function of $Q$. He may also calculate permeation for a stable species with the same values of $D$ and $C_{1}$. Figuic $C-4$ is a plot of the results. The ordinate is atoms $/ \mathrm{cm}^{2} / \mathrm{h}$ (into the tunnel) per atoms/per $\mathrm{cm}^{3}$ void (in the mune wall). For radon222 this ratio has the same numerical value if oute expresses radon-222 in disintegrations per minute (DPM). The thickness of the film in this experiment $(0.137 \mathrm{~mm})$ is marked on the plot.

Given a thickness of $0.137 \mathrm{~mm}$ for the membrane, Fig. C.S is a plot of total atoms of radon-222 downstream per atom/ $\mathrm{cm}^{3}$ upstream, and rate of permeation (per hour) of radon-222 per atom per $\mathrm{cm}^{3}$ upstream.

A previous experiment extending over 5 t failed because the diffusion constant was almost two orders of magnitude less than expected. In an attenipt to gain information for planning the current experiment, the alphaactivity remaining in the foil was determined with a survey meter at various times for two weeks after removal from the radon-222 source. From the observed "half-life", a value of $4.6 \times 10^{-11} \mathrm{~cm}^{2} / \mathrm{s}$ was calculated for $D$. These were crude measurements and this is quite good agreement with the current best value $5.28 \times 10^{-11} \mathrm{~cm}^{2} / \mathrm{s}$. Even with mare sophisticated counting techniques, the determination of total madon-222 in the film (and thus solubility) is complicated by the fact that the film corresponded to 2 to 3 ranges for the alpha-particles involved. This makes absolute counting efficiency very difficult to determine.

However, these observations suggest an attractive technique for determining diffusion constant and solubility of radon-222 in membranes. For films "thin" compared to alpha-particle ranges, the counting efficiency is known. One is speaking generally of films about $1 \mathrm{mil}$ in thickness. One could expose a membrane (or a number of membranes) to a constant known pressure of radon-222 uncil saturation is reached. The membrane(s) could then be removed from the source and total radon-222 determined as a function of time by alpharcounting. For the class 


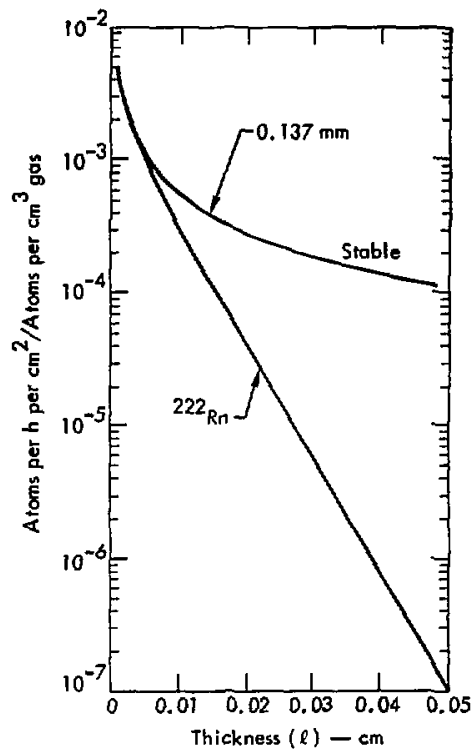

Fig. C-4. Sleady-state pernueation vs thickness (Q).

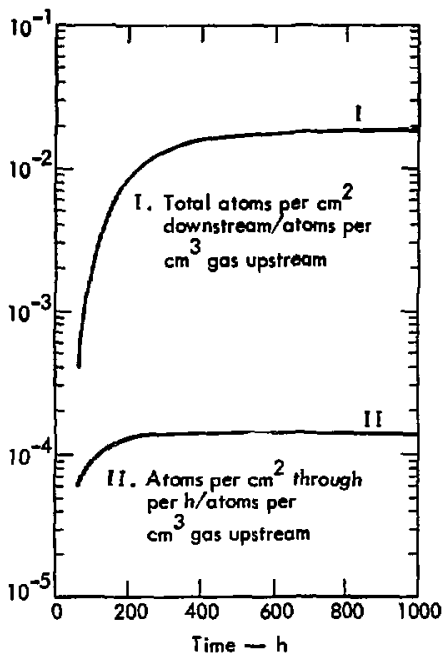

Fig. C.5. Total permeation and rate of permeation vs time. 
of substances with low diffusion constants, theory would then allow deterinination of both diffusion constant and solubility.

We have the following boundary value problem:

$$
\begin{aligned}
& \frac{\partial C}{\partial t}=\frac{D a^{2} C}{\partial x^{2}}-\lambda C \\
& C(x, 0)=C_{1}, 0<x<e \\
& C(0, t)=0 . \text { all } t \\
& C(R, 1)=0, \text { all } t .
\end{aligned}
$$

A substitution, $\Sigma=\mu e^{-\lambda t}$, results in

$$
\frac{\partial \mu}{\partial \mathrm{t}}=\frac{\mathrm{D} \partial^{2} \mu}{\partial \mathrm{x}^{2}}
$$

Other boundary conditions on $\mu$ remain the same.

Ulimately, the solution for $C$ is

$$
C=\frac{4 C_{1} e^{-\lambda t}}{\pi} \sum_{n=1}^{\infty} \frac{\sin \left\{\frac{(2 n-1) \pi x}{\ell}\right\}}{(2 n-1)} e^{-\frac{D(2 n-1)^{2} \pi^{2} t}{\ell^{2}}} .
$$

Also, $Q$, the amount in the membrane at a given time is

$$
Q=\int_{0}^{\ell} C d x=\frac{8 R C_{1} e^{-\lambda t}}{\pi^{2}} \sum_{n=1}^{\infty} \frac{e^{-\frac{D(2 n-1)^{2} n^{2}}{e^{2}}}}{(2 n-1)^{2}} .
$$

This series converges quite rapidly so that one approaches

$$
Q=\frac{88 C_{1}}{\pi^{2}}-\left(\frac{D \pi^{2}}{Q^{2}}+\lambda\right)
$$

$Q(t)$ can be deternined directly by alpha-counting the membrane at a series of times. From its dependence on time, the argument of $t$ in the exponential can be determined. As $R$ and $\lambda$ are known, $D$ cun thus be calculated. Also, once the argument of $t$ is known a value of $C_{1}$ can be culculated front each alpharcount. For values of $D$ and $R$ leading to a time argument corresponding to a "half-life" of less than a fow hours, the presence of the daughters polonjum-218 and polonium-214 of radon-222, introduces some complication in the calculations as their alphaparticles will also be counted. However, this can be handled in a straightiorward manner. 